\author{
UNITED STATES \\ DEPARTMENT OF THE INTERIOR \\ GEOLOGICAL SURVEY
}

\title{
PRELIMINARY INTERPRETATION OF PALEOMAGNETIC AND MAGNETIC PROPERTY DATA FROM DRILL HOLES USW 6-1, G-2, GU-3, 6-3, AND VH-1 AND SURFACE LOCALITIES IN THE VICINITY OF YUCCA MOUNTAIN, NYE COUNTY, MEVADA
}

By

J. G. Rosenbaum and D. B. Snyder

Open-File Report 85-49

Prepared by the U.S. Geological Survey

for the

Nevada Operations Office

U.S. Department of Energy

(Interagency Agreement DE-AI08-78ET44802)

This report is preliminary and has not been reviewed for conformity with II.S. Geological Survey editorial standards and stratigraphic nomenclature. Any use of trade names is for descriptive purposes only and does not imply endorsement by the USGS.

$$
\begin{gathered}
\text { Denver, Colorado } \\
1984
\end{gathered}
$$




\section{CONTENTS}

Abstract.........................................................

Introduction..................................................

Sampl ing Procedure.............................................

Laboratory Procedure............................................

Results .....................................................

Paintbrush Tuff.

Tiva Canyon Member.....................................

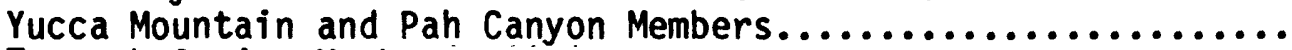

Topopah Spring Member.....................................

Tuffaceous beds of Calico Hills...............................

Crater Flat Tuff...........................................

Prow Pass Member........................................

Bull frog Member.......................................

Tram Member...........................................

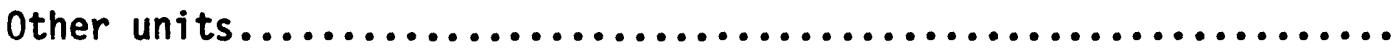

Lava flows and flow breccias between the Tram Member and

the Lithic Ridge Tuff..................................

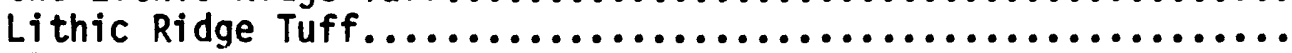

01der tuffs of USW G-1 and lava flows and flow breccias

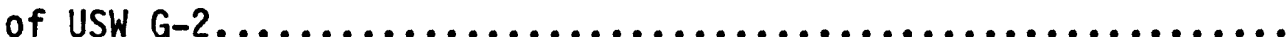

Discussion and Summary...........................................

References..................................................

\section{ILLUSTRATIONS}

Figure 1. Location of drill holes and outcrop sampling sites in the vicinity of Yucca Mountain....................

2. Equal area projection of paleomagnetic data for the Tiva Canyon Member of the Paintbrush Tuff.............

3. Pal eomagnetic data versus depth for the Yucca Mountain, Pah Canyon and Tiva Canyon Members of the Paintbrush Tuff........................................

4. Intensity of natural remanent magnetization and susceptibility versus depth for the Yucca Mountain, Pah Canyon and Tiva Canyon Members of the Paintbrush

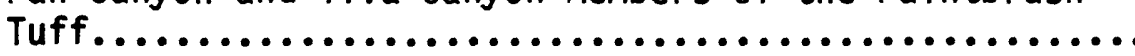

5. Equal area projection of paleomagnetic data for the Yucca Mountain and Pah Canyon Members of the Paintbrush Tuff.

6. Equal area projection of paleomagnetic data for the Topopah Spring Member of the Paintbrush Tuff...........

7. Paleomagnetic data versus depth for the Topopah Spring Member of the Paintbrush Tuff........................

8. Intensity of natural remanent magnetization and susceptibility versus depth for the Topopah Spring Member of the Paintbrush Tuff.........................

9. Paleomagnetic inclinations versus depth for the tuffaceous beds of Calico Hills...................... 


\section{ILLUSTRATIONS--CONTINUED}

Figure 10. Intensity of natural remanent magnetization and

Page susceptibility versus depth for the for the tuffaceous beds of Calico Hills..................... 32

11. Equal area projection of paleomagnetic data for the Prow Pass Member of the Crater Flat Tuff............. 35

12. Paleomagnetic inclinations versus depth for the Prow Pass Member of the Crater Flat Tuff.................. 36

13. Intensity of natural remanent magnetization and susceptibility versus depth for the Prow Pass Member of the Crater Flat Tuff.................... 38

14. Equal area projection of paleomagnetic data for the Bullfrog and Tram Members of the Crater Flat Tuff...... 41

15. Paleomagnetic inclinations versus depth for the Bull frog Member of the Crater Flat Tuff...............

16. Intensity of natural remanent magnetization and susceptibility versus depth for the Bullfrog Member of the Crater Flat Tuff............................

17. Paleomagnetic inclinations versus depth for the Tram Member of the Crater Flat Tuff......................

18. Intensity of natural remanent magnetization and susceptibility versus depth for the Tram Member of the

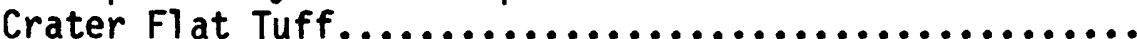

19. Paleomagnetic inclinations versus depth for the dacite and rhyodacite lava flows and flow breccias between

the Tram Member of the Crater Flat Tuff and the

Lithic Ridge Tuff

20. Intensity of natural remanent magnetization and susceptibility versus depth for the dacite and rhyodacite lava flows and flow breccias between the Tram Member of the Crater Flat Tuff and the Lithic Ridge Tuff.....................................

21. Paleomagnetic inclinations versus depth for the Lithic Ridge Tuff. 56

22. Equal area projection of paleomagnetic data for the Lithic Ridge Tuff.

23. Intensity of natural remanent magnetization and susceptibility versus depth for the Lithic Ridge Tuff..

24. Intensity of total magnetization versus depth for drill holes USW G-1, G-2, GU-3 and G-3, and a modeled total field $10 \mathrm{~g}$ for drill hole USW G-1.........

\section{TABLES}

Table 1. Paleomagnetic directional data for the Tiva Canyon Member of the Paintbrush Tuff, the Tuff of Chocolate Mountain, and the Tuff of Pinion Pass........................

2. Magnetic property data for the Tiva Canyon Member of the Paintbrush Tuff and the Tuff of Chocolate Mountain..... 
Table 3. Paleomagnetic directional data for the Yucca Mountain

Memeber of the Paintbrush Tuff......................

4. Paleomagnetic directional data for the Pah Canyon Member of the Paintbrush Tuff............................ 13

5. Magnetic property data for the Yucca Mountain Member of the Paintbrush Tuff............................ 15

6. Magnetic property data for the Pah Canyon Member of the Paintbrush Tuff................................ 16

7. Paleomagnetic directional data for the Topopah Spring Member of the Paintbrush Tuff..................... 18

8. Magnetic property data for the Topopah Spring Member of the Paintbrush Tuff........................... 27

9. Magnetic property data for the tuffaceous beds of Calico Hills...................................... 31

10. Paleomagnetic directional data for the Prow Pass Member of the Crater Flat Tuff........................... 34

11. Magnetic property data for the Prow Pass Member of the Crater Flat Tuff............................... 37

12. Paleomagnetic directional data for the Bullfrog Member of the Crater Flat Tuff.......................... 40

13. Magnetic property data for the Bullfrog Member of the Crater Flat Tuff.

14. Pal eomagnetic directional data for the Tram Member of the Crater Flat Tuff.

15. Magnetic property data for the Tram Member of the Crater Flat Tuff...

16. Magnetic property data for the dacite and rhyodacite lava flows and flow breccias between the Tram Member of the Crater Flat Tuff and the Lithic Ridge Tuff.........

17. Paleomagnetic directional data for the Lithic Ridge Tuff.........................................

18. Magnetic property data for the Lithic Ridge Tuff...........

19. Paleomagnetic directional data for the older tuffs of

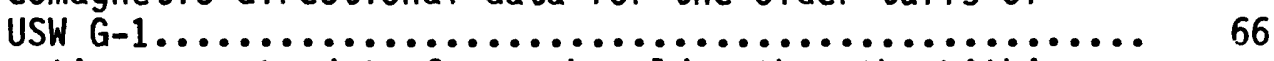

20. Magnetic property data for rocks older than the Lithic Ridge Tuff................................. 67

21. Paleomagnetic polarities of volcanic rocks at Yucca

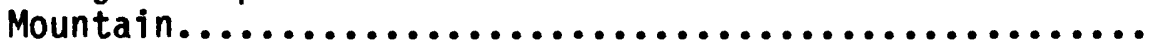




\author{
UNITED STATES \\ DEPARTMENT OF THE INTERIOR \\ U.S. GEOLOGICAL SURVEY
}

\title{
PRELIMINARY INTERPRETATION OF PALEOMAGNETIC AND MAGNETIC PROPERTY DATA FROM DRILL HOLES USH G-1, 6-2, GU-3, 6-3, AND VH-1 AND SURFACE LOCALITIES IN THE VICINITY OF YUCCA MOUNTAIN, NYE COUNTY, NEVADA
}

\section{By}

\author{
J. G. Rosenbaum and D. B. Snyder
}

\begin{abstract}
Measurements of magnetic properties and paleomagnetic directions have been made on thousands of samples of Miocene age volcanics from drill core and surface localities in and around Yucca Mountain at the Nevada Test Site. The directional data have firmly established paleomagnetic polarities for the various members of the Paintbrush and Crater Flat Tuffs, and for the Tuffaceous Beds of Calico Hills. In addition, the Lithic Ridge Tuff is found to have a highly unusual paleomagnetic direction (southwest and nearly horizontal). Changes in inclination of remanence with depth in the Tuffaceous Beds of Calico Hills indicate that this unit was emplaced over a substantial period of time relative to secular variation of the geomagnetic field, and that the relatively thin sequence of tuffs of this unit encountered at the USW G-1 locality correlates roughly with the basal $125 \mathrm{~m}$ of the much thicker sequence penetrated in drill hole USW G-2.

Paleomagnetic data obtained for the Topopah Spring Member of the Paintbrush Tuff from cores from drill holes at Yucca Mountain and from outcrop at Busted Butte demonstrate that the remanence directions of this unit vary with depth. The cause of this variation is presently unknown and its presence severely limits the usefulness of the paleomagnetic method as a tool for examining structural rotations affecting the Topopah Spring Member. In contrast, the Tiva Canyon Member of the Paintbrush Tuff yields essentially one direction of remanence everywhere it has been sampled at Yucca Mountain. The near coincidence of paleomagnetic directions obtained for Tiva Canyon sites from throughout Yucca Mountain indicates that the change in strike of eutaxitic foliation and of the base of this unit in the vicinity of Drill Hole Wash cannot be due to structural rotation about a vertical axis, but does not rule out rotations of a few degrees about horizontal axes.

Four widespread units, the Tiva Canyon and Topopah Spring Members of the Paintbrush Tuff and the Bullfrog and Tram Members of the Crater Flat Tuff, are identified as potential sources of significant magnetic anomalies by measurements of remanent intensity and susceptibility. The measurements also demonstrate large variations in remanent intensity and susceptibility within individual ash-flow sheets. In some cases these variations are closely
\end{abstract}


related to geologically recognizable breaks in ash-flow tuff deposition. These variations provide the possibility of using magnetic field logs not only to locate major stratigraphic contacts but also to map subunits within the major ash-flow sheets.

\section{INTRODUCTION}

The strata underlying Yucca Mountain comprise a thick sequence of Miocene age volcanic rocks. The Tiva canyon Member of the Paintbrush Tuff is exposed over most of the surface of Yucca Mountain. Nearly 2 kilometers of ash-flow tuffs and related bedded tuffs were penetrated in drill holes USW G-1, G-2, GU-3, and G-3. In descending stratigraphic order the units are the Tiva Canyon, Yucca Mountain, Pah Canyon, and Topopah Spring Members of the Paintbrush Tuff, the tuffaceous beds of Calico Hills, the Prow Pass, Bullfrog and Tram Members of the Crater Flat Tuff, unnamed rhyodacite and dacite lava flows and flow breccias, the Lithic Ridge Tuff, and unnamed older lavas and tuffs. Detailed lithologic descriptions of the drill core are provided by Spengler and others [1981], Maldonado and Koether [1983], and Scott and Castellanos [1984].

Measurements of remanent magnetization and magnetic susceptibility of samples of volcanic rocks from bore holes and surface outcrops in the vicinity of Yucca Mountain have been used as stratigraphic correlation tools, as limitations on structural interpretations [Spengler and Rosenbaum, 19807, and as guides to the interpretation of magnetic anomalies in the area [Bath and Jahren, 1984]. Also these data should prove useful in the interpretation of in-hole magnetic-field and magnetic-susceptibility logs.

While the direction of remanent magnetism is useful in volcanic stratigraphic correlation and in the solution of structural problems, the direction and intensity of total magnetization, $\vec{J}_{t}$, is needed for the interpretation of magnetic anomalies. The total magnetization of a rock specimen is the vector sum of its remanent and induced magnetizations, so that

$$
\vec{J}_{t}=\vec{J}_{r}+\vec{J}_{j}=\vec{J}_{r}+\frac{k}{\mu_{0}} \vec{B}
$$

where $\vec{J}_{t}, \vec{J}_{r}$, and $\vec{J}_{j}$ are total, remanent, and induced magnetizations in amperes per meter $\left(A_{m}^{-1}\right)$, respectively; $\mathcal{X}$ is the bulk susceptibility (dimensionless); $B$ is the magnetic flux ( $\vec{B}$ has a magnitude of about $0.517 \times 10^{-4}$ tesla (T) at NTS); and $\mu_{0}$ is the permeability of free space $\left(\mu_{0}=4 \pi \times 10^{-7}\right.$ $\left.T m A^{-1}\right) . \vec{J}_{r}$ and $K$ can be easily measured in the laboratory.

The purpose of this report is to document magnetic property data for specimens collected during 1980-83 from drill holes USW G-1, G-2, GU-3, G-3, and $\mathrm{VH}-1$ as well as from surface sampling localities on and around Yucca Mountain. Preliminary interpretations are also presented.

\section{SAMPLING PROCEDURE}

Cylindrical samples, approximately $2.5 \mathrm{~cm}$ in both length and diameter, were collected from outcrops and drill core. A sun compass was used to orient outcrop samples [Creer and Sanver, 1967.]. Orientation with respect to the drill hole axes was maintained for all samples collected from drill core. In addition, samples from oriented core segments were collected in a 
manner which preserved the orientation information [Spengler and Rosenbaum, 1980].

Sampling of outcrops has the advantage that accurate orientation of all samples is easily obtained by standard techniques. However, outcrop sampling has a number of disadvantages: (1) sampling is restricted to the limited stratigraphic section exposed in the area; (2) sampling vertically through a unit is often difficult due to incomplete exposure; (3) magnetic properties of samples may have been affected by weathering and therefore may not be representative of a large volume of rock; and (4) remanent magnetism at some localities has been altered by lightning strikes. Sampling cores from deep drill holes eliminates these problems. However, oriented core was obtained for only a small percentage of the drilled section because azimuthal orientaion of deep drill cores is difficult and expensive. Also the magnitude of the errors involved in the orienting procedure are much greater than those for outcrop sampling. Thus, the declination of magnetic remanence cannot be obtained for most of the samples taken from the deep drill holes. Moreover, it should be noted that inclination values from unoriented core cannot be corrected for deviation of the drill hole from vertical. Therefore, directional data from oriented samples presented on equal-area projections and in tables have been corrected for the drill hole orientation, whereas the inclination data for all samples plotted versus depth is oriented with respect to the drill hole axis.

\section{LABORATORY PROCEDURES}

The natural remanent magnetism (NRM) of each specimen was measured with a spinner magnetometer or, in some cases, with a cryogenic magnetometer. A11 outcrop samples were subjected to progressive al ternating field (af) demagnetization to isolate a stable remanence direction. Selected samples from each unit encountered in the drill cores were also subjected to progressive af demagnetization to peak fields of 80 or $100 \mathrm{mT}$. In most cases it was found that the direction of these samples changed little during the cleaning process. All subsurface samples were demagnetized at a peak field of $10 \mathrm{mT}$.

Susceptibilities were determined on a precisely calibrated [Rosenbaum and others, 1979], highly sensitive bridge [Cristie and Symons, 1969]. A value of $51,700 \mathrm{nT}$ was used for the earth's field in calculating the induced magnetization.

For the purpose of calculating total magnetization, each sample from drill core was assigned a remanent declination. In most cases the declination was obtained by averaging directions from measurements made on oriented specimens from the same geologic unit. In a few instances a declination of $0^{\circ}$ $\left(180^{\circ}\right)$ was assigned to units which appeared to be normal (reversed) based on inclination data alone. In the text which follows "polarities," "directions," and "intensities of magnetization" refer to remanent magnetization unless otherwise specified as referring to total magnetization. 


\section{RESULTS}

\section{Paintbrush Tuff}

Tiva Canyon Member: The Tiva Canyon Member was sampled extensively in outcrop and in drill hole USW GU-3 (Figure 1). Outcrop sampling sites for the Tiva Canyon Member range from near the base of the unit to near its top. The Tiva Canyon was sampled throughout most of its thickness at site SJ82-1 and in drill hole USW GU-3. In addition, a small number of samples of the Chocolate Mountain Tuff (intracaldera equivalent to the uppermost part of the Tiva Canyon Member) and of the closely associated Tuff of Pinion Pass [Byers and others, 1976; Christiansen and others, 1976] were obtained.

All samples are of reversed polarity. The directions obtained from the Chocolate Mountain Tuff and the Tuff of Pinon Pass are essentially indistinguishable from those determined for the Tiva Canyon Member (Table 1). The directional data from the Tiva Canyon Member at Yucca Mountain are closely grouped (Figures 2 and 3, and Table 1) indicating that the Tiva Canyon Member possesses essentially one direction of remanent magnetization throughout its thickness everywhere at Yucca Mountain. The close agreement of the directions from the Yucca Mountain block indicates that there has been little, if any, relative rotational deformation within Yucca Mountain since the emplacement of the Tiva Canyon. Although changes in the strike of eutaxitic foliation and of the base of the Tiva Canyon (see figure 6 in Spengler and Rosenbaum, 1980) cannot be due to rotation about a vertical axis, these data do not exclude the possibility of small rotations about horizontal axes. Alternatively, the changes in strike may be depositional rather than tectonic in nature.

The Tiva Canyon Member sampled in USW GU-3 exhibits large changes in both the intensity of remanent magnetization and susceptibility with depth. The variation in remanent intensity defines a relatively simple pattern; the values decrease abruptly with increasing depth from about $2 \mathrm{Am}^{-1}$ to less than $0.3 \mathrm{Am}^{-1}$ and then increase gradually to a depth of about $75 \mathrm{~m}$ (Figure 4). Below this depth the values alternately increase and decrease, defining three increasingly large maxima. Susceptibilities display a more complex pattern of variation which shows little correlation to that of the intensity of magnetization. The sharp increase of intensity and susceptibility at the top of the sampled section corresponds to an increase in phenocryst and mafic mineral content, and the intensity maximum at a depth of about $105 \mathrm{~m}$ occurs within the basal vitrophyre [Scott and Castellanos, 1984]. Also the rapid fall in intensity at the base of the unit corresponds to the decrease in welding at the base of the ash-flow sheet. No other correlation between intensity and/or susceptibility changes and changes in the lithology described by Scott and Castellanos [1984] are obvious.

Similar variations of susceptibility and magnetization occur at site SJ82-1 (Figure 4). Average values of magnetization and susceptibility from surface localities within the Yucca Mountain block are in good agreement with the data from USW GU-3 (Table 2). The highest average magnetizations are from sites M79-25, M79-26 and JR81-8 which are all located in a densely welded, columnarly jointed zone near the base of the Tiva Canyon Member. As in the results from USW GU-3, these high intensity values are associated with relatively low values of susceptibility. Sampling locality JR81-2 is located 


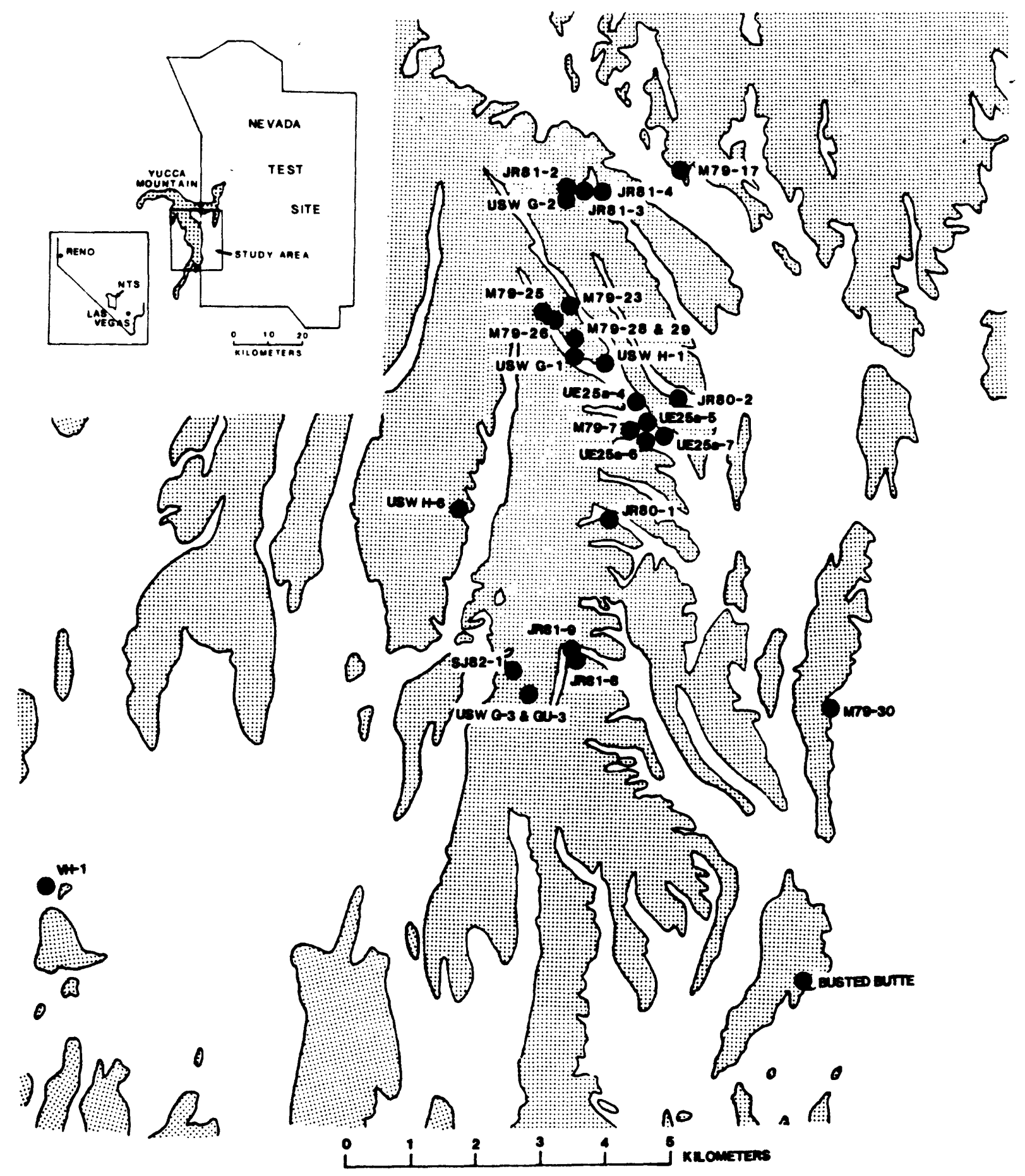

Figure 1.--Locations of drill holes and outcrop sampling sites in the vicinity of Yucca Mountain. Shading Indicates area where bedrock is largely exposed. 
Table 1. O1rectional data for the Tiva Canyon Member, the Chocolate Mountain Tuff, and the Tuff of P1non Pass

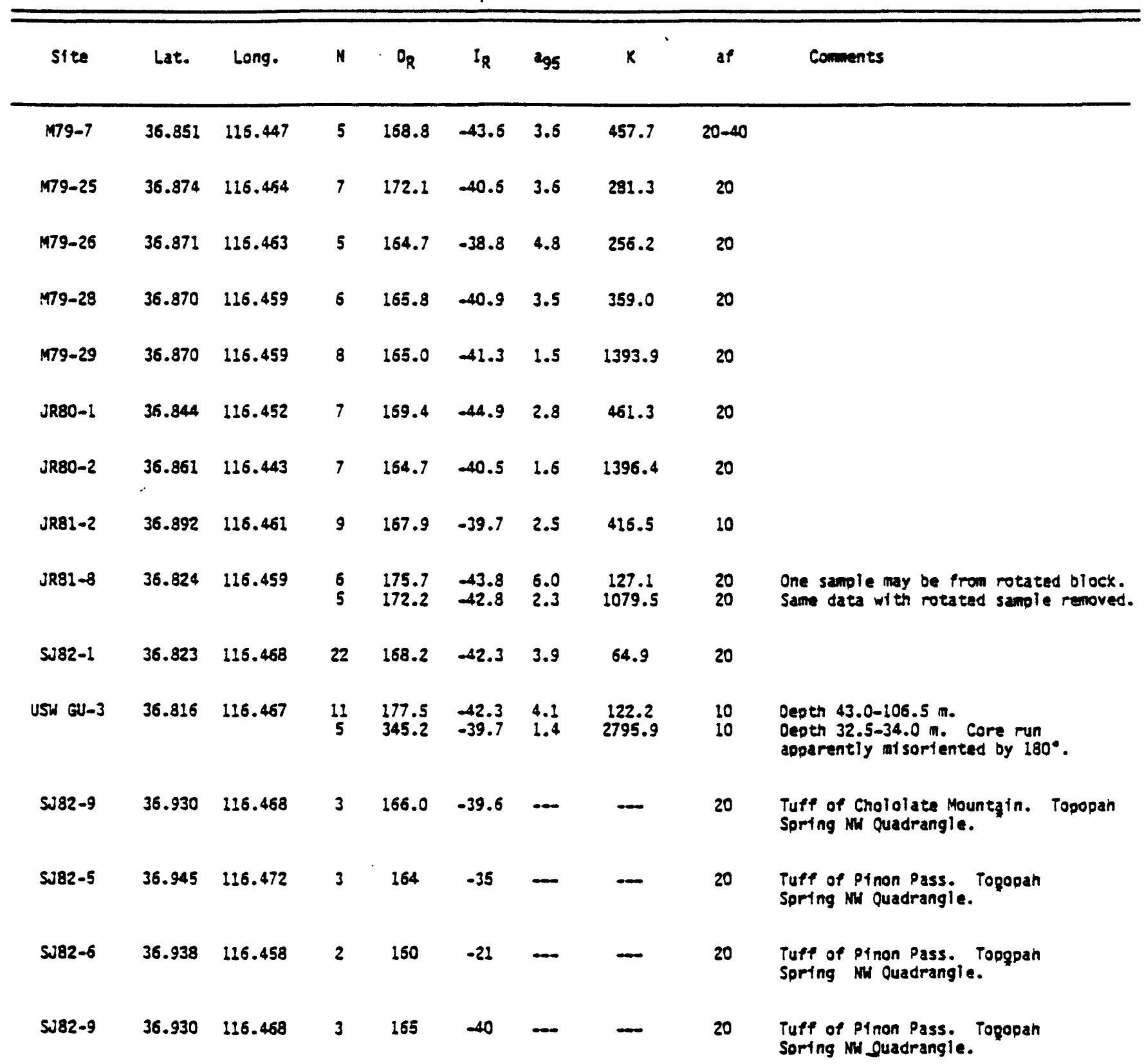

$N$ is the number of samoles used in calculating the mean. $O_{R}$ and $I_{R}$ are the average declination and incl ination of remanence, respectively; ags is the half angle of the cone of $958^{R}$ confidence; $K$ is the fisher precision parameter; af is the alternating ffeld demagnetization step used to calculats the mean directions. indicates sits not shown in Figure 1 . 


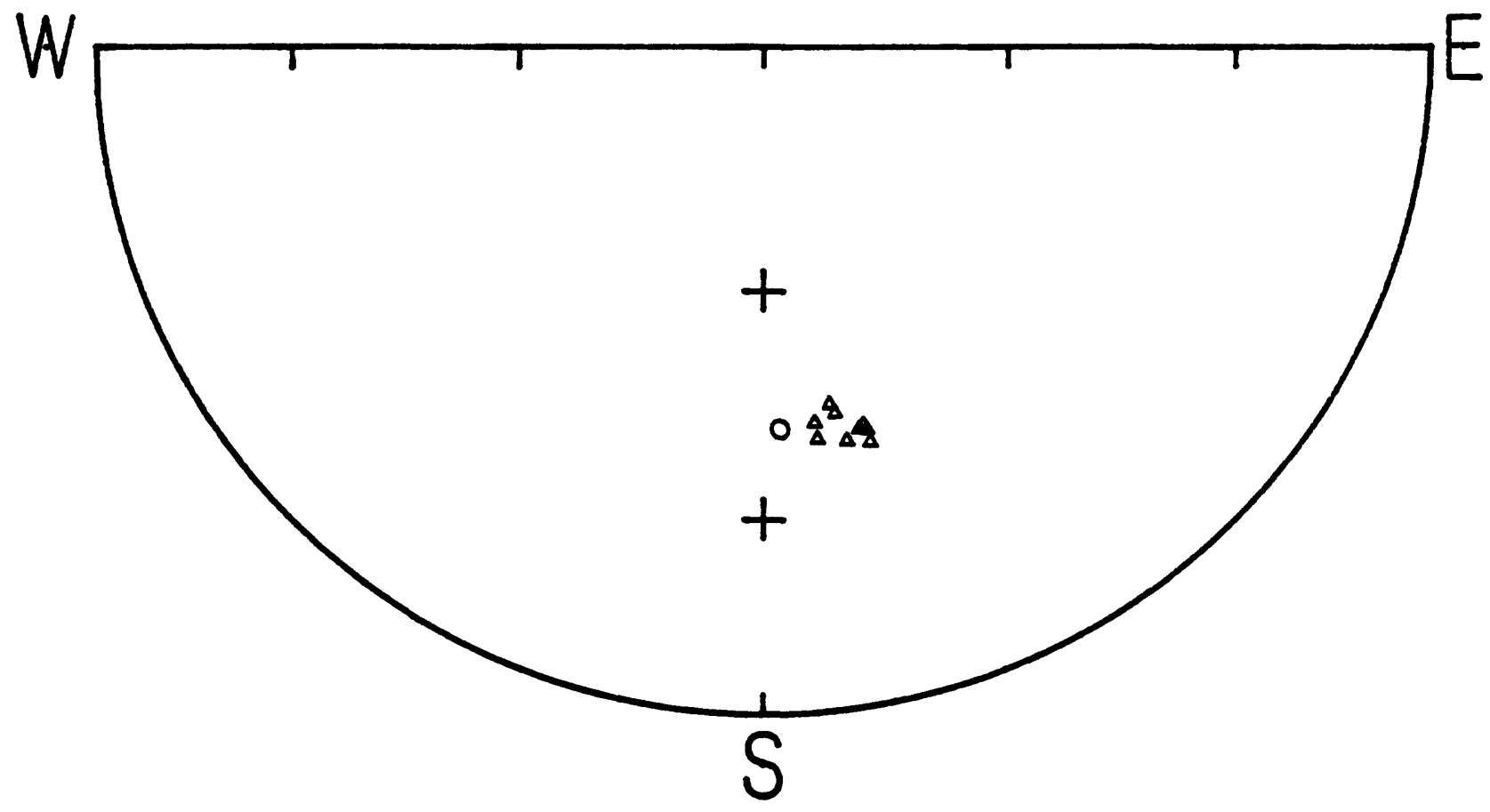

Figure 2.-Equal area projection of paleomagnetic data from the Tiva Canyon Member of the Paintbrush Tuff (Table 1). Triangles and circle are mean directions for outcrop sites and drill hole USW GU-3, respectively. 


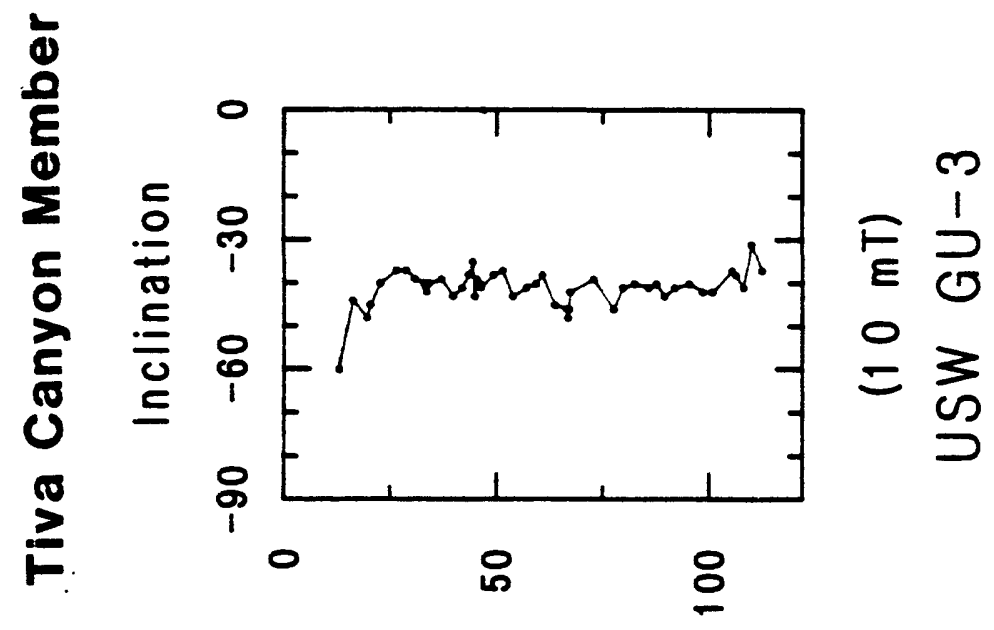

$\frac{1}{0}$

굴

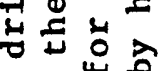

틍 w

出 0 ○

4 足 던

ป 정

등 륭

हैं

을

ع

ค

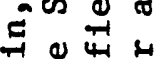

का

넝 월

일

藏

论

궁

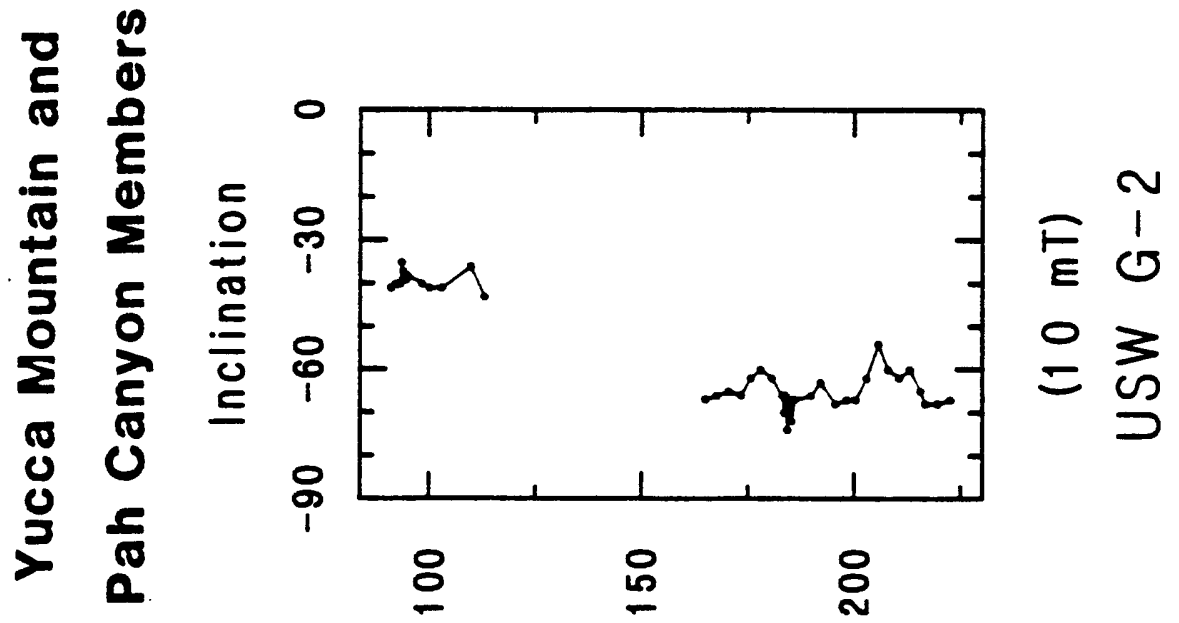

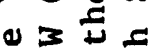

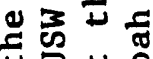

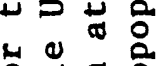
엉 훙 웅 4 오 어 党古 岀 ए) 대 4 ठठ

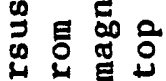
4 른 $\stackrel{4}{>} \stackrel{0}{0}$ त 54 岑 유 ○范

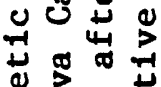
車出 क स स

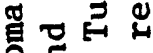

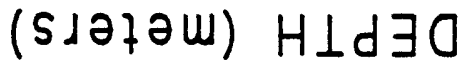




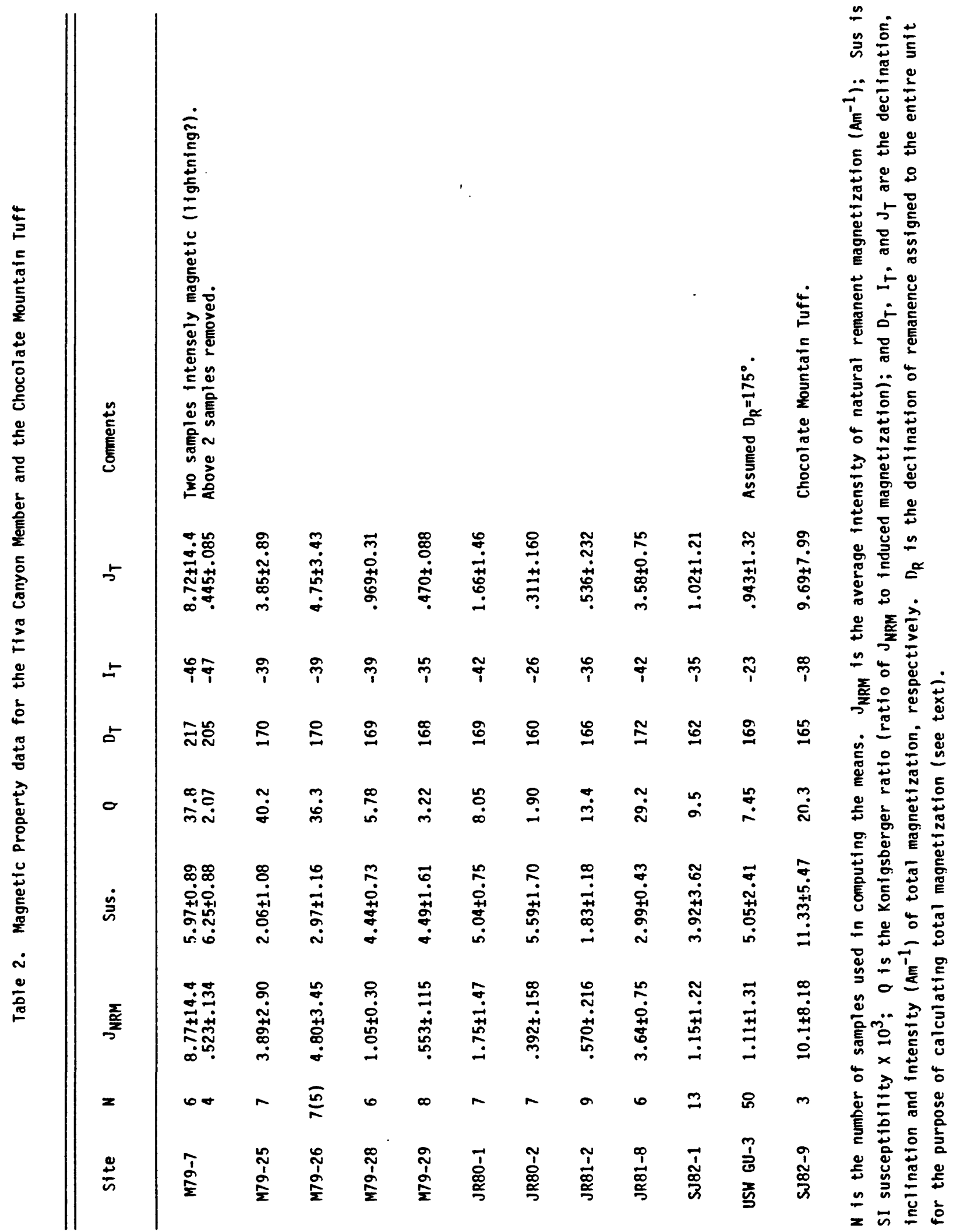




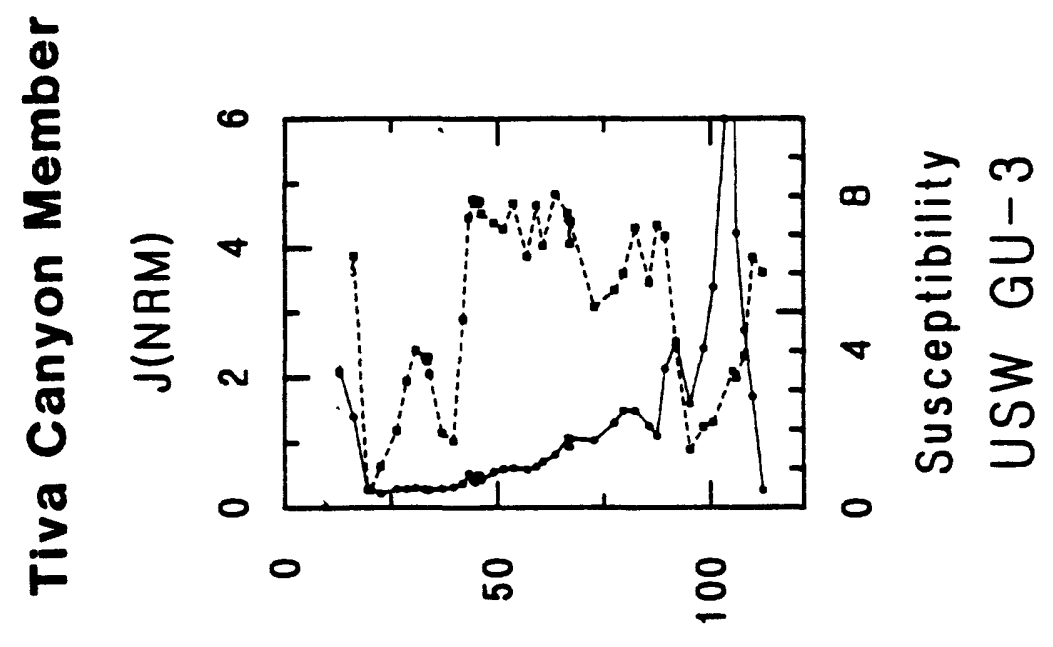

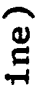
퉁

0 ટ

겅 ฮู

$\infty$ 正

कि ले



氙出

青宁

氙完

$1 \quad$ 导

是司忌

동

$\rightarrow$ 리

ค

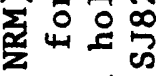

万骂

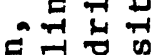

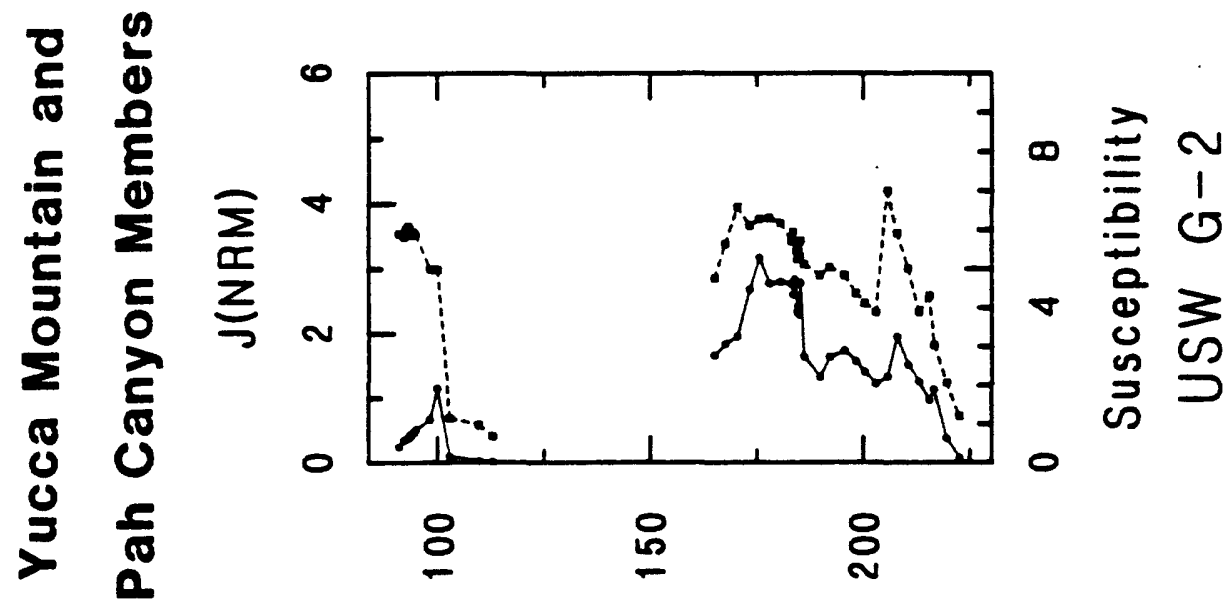

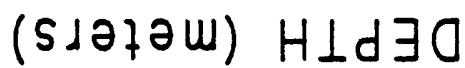

잉ㅎㅇ

政出

需电

吃 웅

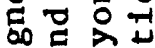

娄

过四

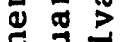

क्ष

罜导出 ㄷํㅇ ำล ํㅣㄹ 吾㫮 岁夏号

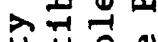
点苔 U $=$ 过思寻㟔

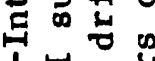
|出自 있 0 出 $\underset{3}{9}$ 
in the upper portion of the unit (below the cap rock) and is characterized by relatively low values of both susceptibility and magnetization. The other sites are located in the more central portion of the ash-flow tuff and possess relatively high susceptibilities and low to intermediate intensities. Three samples of the tuff of Chocolate Mountain from site SJ82-9 yield high values of both remanent intensity and susceptibility (Table 2).

Yucca Mountain and Pah Canyon Members: Two relatively thin local members of the Paintbrush Tuff, the Yucca Mountain and Pah Canyon Members, were each sampled at two outcrop localities (Figure 1). Oriented specimens of the Pah Canyon Member were also obtained from drill hole USW G-2. Both units are of reversed polarity with the inclination of remanence for the Pah Canyon Member being significantly steeper than that of the Yucca Mountain Member (Figures 3 and 5 and Tables 3 and 4 ).

Intensity and susceptibility data for the Yucca Mountain and Pah Canyon Members are presented in Figure 4 and Tables 5 and 6 . The Yucca Mountain Member possesses low remanent intensities (average less than $0.4 \mathrm{Am}^{-1}$ ) and relatively high susceptibilities so that values of $Q$ for this unit are among the lowest determined in the area.

Susceptibilities of Pah Canyon Member samples are in the same general range as those of the Yucca Mountain Member. In contast, the remanent intensities of the Pah Canyon Member average nearly an order of magnitude greater than those of the Yucca Mountain Member. Also, in contrast to the case for the Tiva Canyon Member, there is obviously a high degree of correlation between changes in remanent intensity and susceptibility in the Pah Canyon Member (Figure 4). It should be noted, however, that the maxima and minima for these curves are offset by a few meters. 


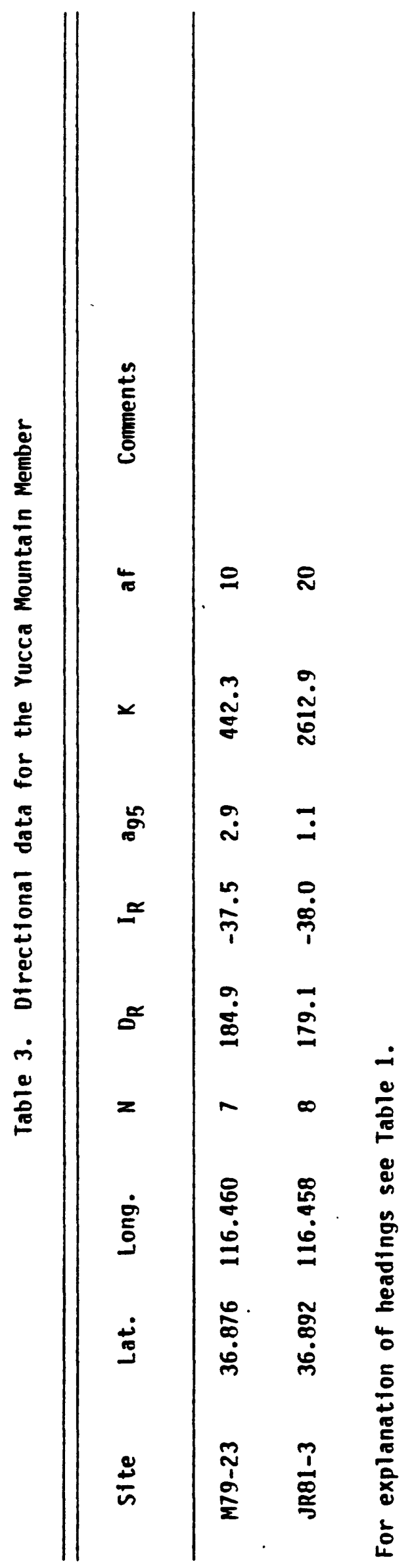




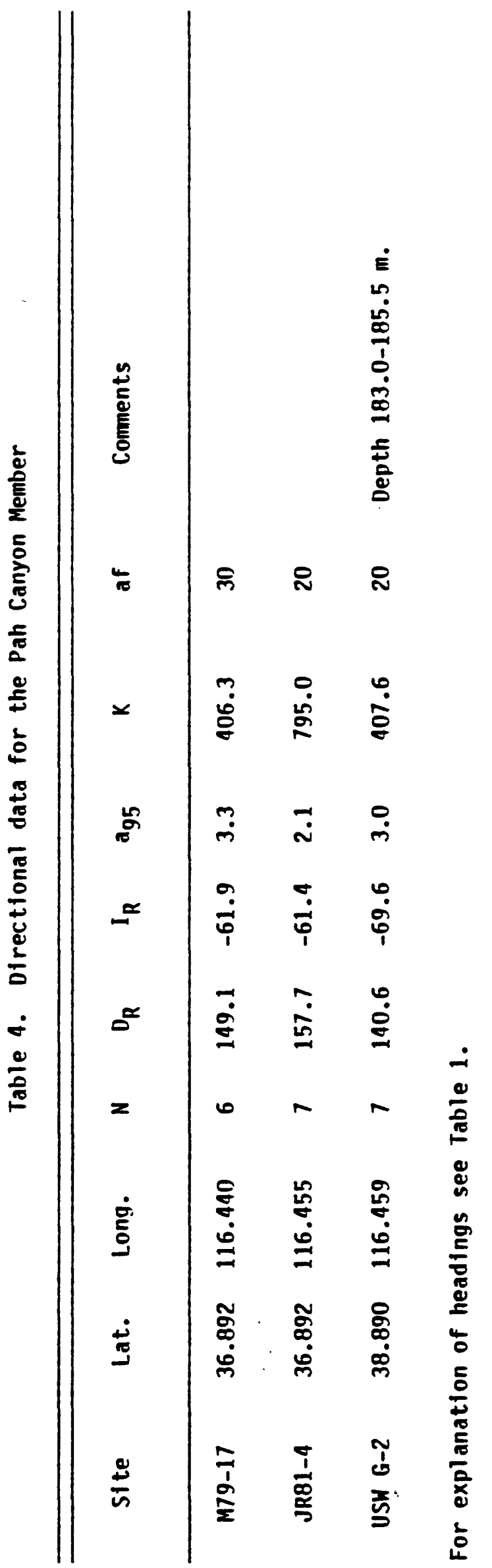




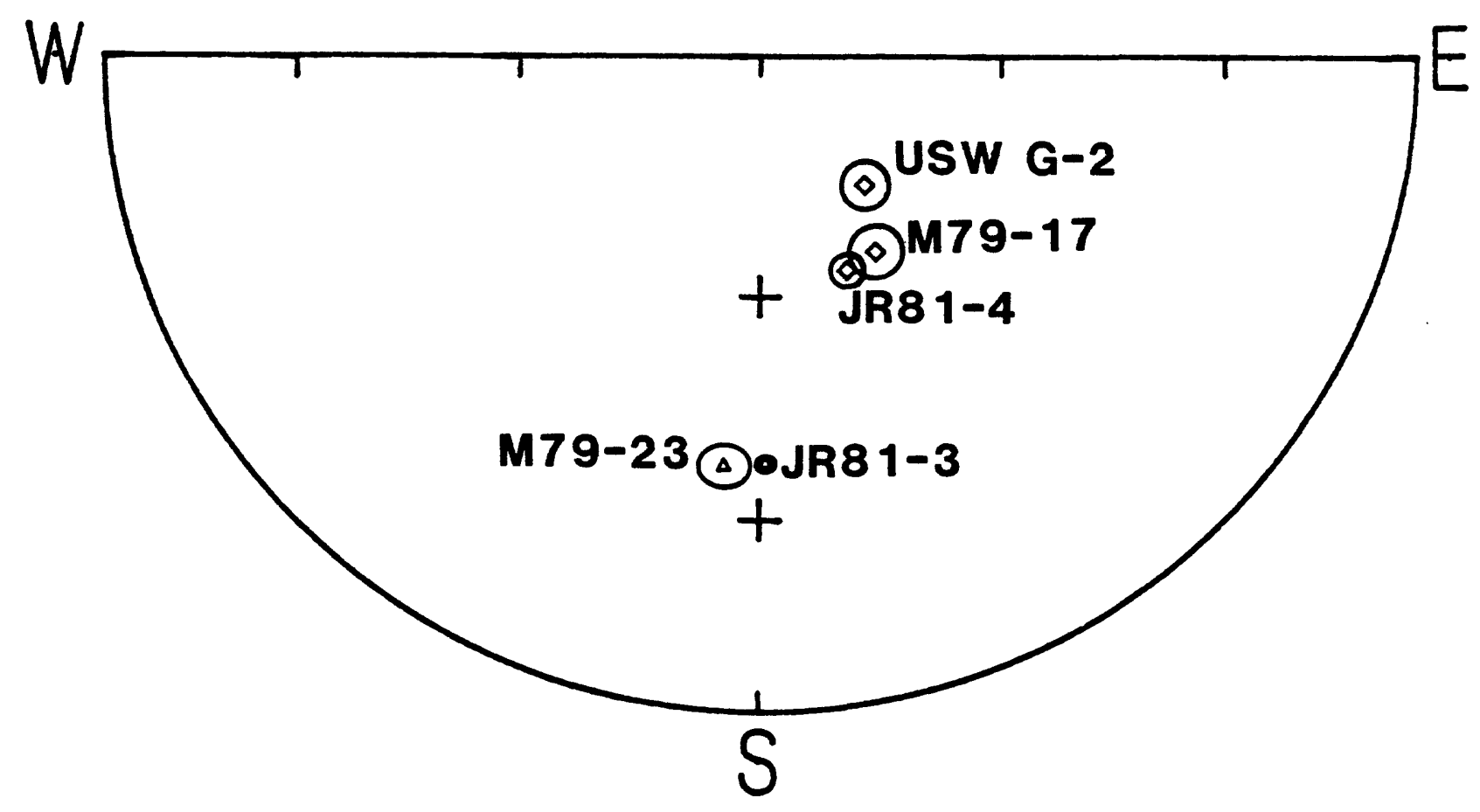

Figure 5.-Equal area projection of paleomagnetic data and associated cones of 95\% confidence for the Yucca Mountain (triangles) (see Table 3) and Pah Canyon (diamonds) (see Table 4) Members of the Paintbrush Tuff. 


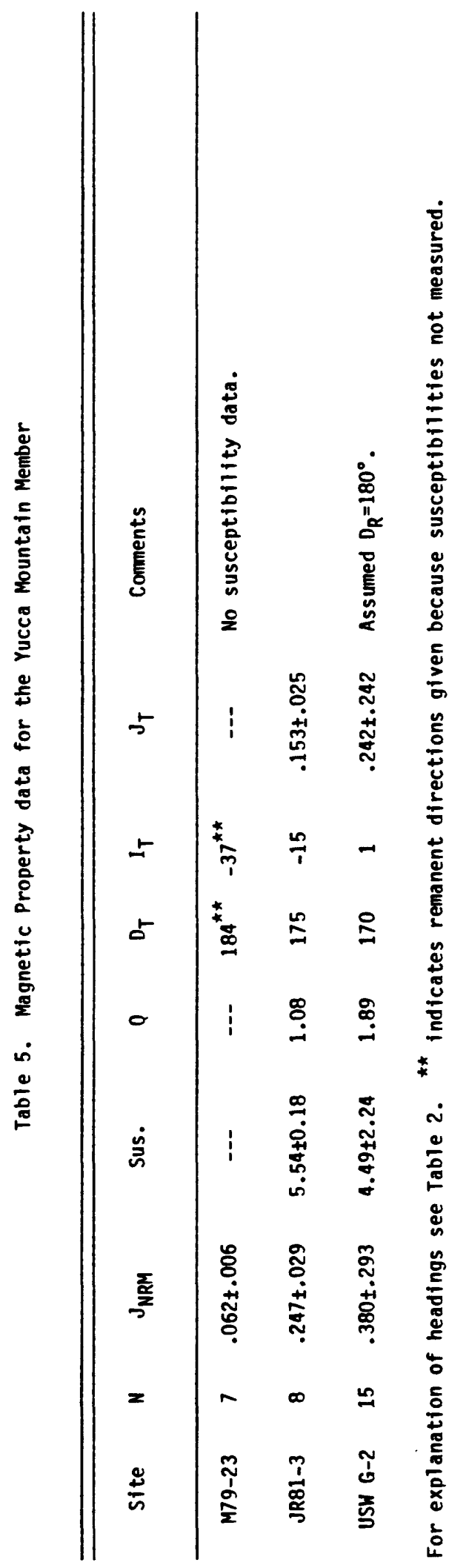




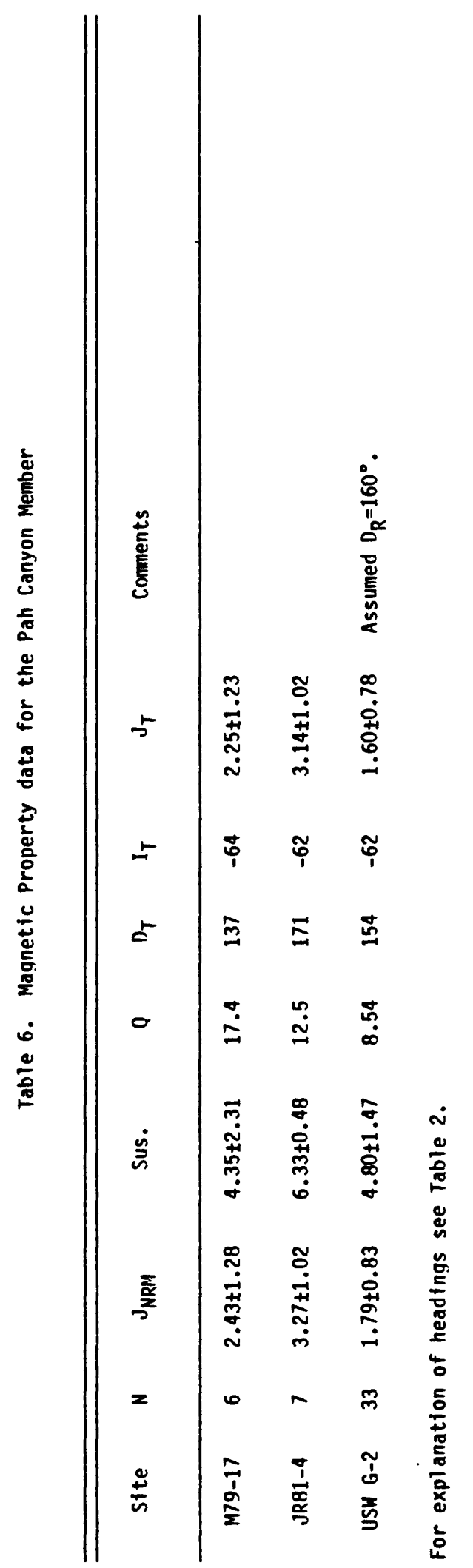


Topopah Spring Member: The Topopah Spring Member was sampled at four outcrop localities (Figure 1) and in drill holes USW G-1, G-2, GU-3, H-1, UE25a-4, -5, -6 , and -7 (Table 7 ).

Data from drill holes USW G-1, G-2 and GU-3 and from outcrop sampling at Busted Butte have demonstrated large changes in remanent directions with depth within the Topopah Spring Member (Figures 6a, 6b, $6 c$ and 7). These directional variations make structural interpretations based upon differences in remanent directions of the Topopah Spring Member, such as those observed between samples from drill holes UE25a-4, $-5,-6$, and -7 (Figure 6d) [Spengler and Rosenbaum, 1980], tenuous at best. The reason for these changes is not clear. The directional variations may be due to changes in the magnetic field during cooling of the ash-flow sheet. Alternatively, they could be produced by internal deformation of the sheet by postemplacement flow at temperatures below which the magnetization was acquired. This latter possibility is consistent with the observation that inclinations decrease with depth from values near the expected axial dipole inclination, to values as low as $20^{\circ}$, and then increase sharply near the bottom of the unit (Figure 7). The shallow inclinations could be due to a process similar to that which produces an "inclination error" in sediments [King, 1955]. In this case rotation of the magnetic grains would presumably take place during the welding process. This hypothesized mechanism would require some of the welding to have occurred at temperatures below those at which the magnetization was blocked (i.e. over a range of temperatures below the Curie temperature of about $575^{\circ} \mathrm{C}$ ). The steepening of inclinations below the bottom of the basal vitrophyre (at depths of $409 \mathrm{~m}, 508 \mathrm{~m}$, and $387 \mathrm{~m}$ in drill holes USW G-1, G-2, and GU-3, respectively) may be related to a lessening of the amount of grain rotation with a decrease in welding toward the base of the ash-flow sheet. In contast, because there is little variation in the degree of welding in the $200 \mathrm{~m}$ of tuff overlying the basal vitrophyre (all moderately to densely welded), progressive flattening of the remanence vector with depth would require a systematic variation in the proportion of grain rotations that occurred before and after blocking of the remanence. Horizontal shearing accompanying the compactional process would cause a bias in the direction of grain rotation and thereby cause changes in the declination of remanence.

It should be noted that some of the observed directional variation may be due to rotation of blocks in proximity to faults. For example, the sample from a depth of $397 \mathrm{~m}(1302.5 \mathrm{ft})$ in USW G-2 (Figure 7) which has an inclination in excess of $80^{\circ}$ occurs in a zone of shear fractures (396.2-398.4 m) [Maldonado and Koether, 1983]. In addition it is worth noting that the direction from one sampling site outside of the Yucca Mountain block, M79-10, is nearly $20^{\circ}$ steeper than any of the site means from Yucca Mountain and about $12^{\circ}$ greater than the most steeply inclined data from the drill holes (Figure $6 e$ and Table 7). This suggests some relative rotation between the Yucca Mountain block and site M79-10. 
Table 7. Directional data for the Topopah Spring Member

\begin{tabular}{|c|c|c|c|c|c|c|c|c|c|}
\hline site & Lat. & Long. & $N$ & $D_{R}$ & $I_{R}$ & $a_{95}$ & $k$ & af & Comnents \\
\hline$M 79-10$ & 36.772 & 116.316 & 6 & 304.0 & 75.3 & 2.0 & 1141.0 & 20 & $\begin{array}{l}\text { North end of Little Skull Mountain. } \\
\text { Jackass Flats Quadrangle. }\end{array}$ \\
\hline$M 79-30$ & 36.816 & 116.413 & 7 & 288.2 & 53.6 & 4.2 & 209.2 & 20 & \\
\hline JR81-9 & 36.824 & 116.459 & 7 & 297.5 & 53.4 & 2.6 & 543.8 & 20 & \\
\hline $\begin{array}{l}\text { Busted } \\
\text { Butte }\end{array}$ & 36.778 & 116.417 & 96 & 313.7 & 56.6 & 2.2 & 44.0 & 20 & $\begin{array}{l}\text { Southeast side of Busted Butte. } \\
\text { Topopah Spring SW Quadrangle. }\end{array}$ \\
\hline USW G-1 & 36.867 & 116.458 & $\begin{array}{c}22 \\
9 \\
6 \\
7\end{array}$ & $\begin{array}{l}309.6 \\
282.4 \\
292.1 \\
359.7\end{array}$ & $\begin{array}{l}57.0 \\
57.0 \\
46.4 \\
49.7\end{array}$ & $\begin{array}{l}8.8 \\
5.4 \\
1.6 \\
4.7\end{array}$ & $\begin{array}{c}13.4 \\
92.5 \\
1858.2 \\
164.3\end{array}$ & $\begin{array}{l}10 \\
10 \\
10 \\
10\end{array}$ & $\begin{array}{l}\text { All oriented specimens. } \\
\text { Depth } 194.0-200.0 \mathrm{~m} \text {. } \\
\text { Depth } 221.5-225.0 \mathrm{~m} \text {. } \\
\text { Depth } 356.0-359.0 \mathrm{~m} \text {. }\end{array}$ \\
\hline \multirow[t]{3}{*}{ USW G-2 } & 36.890 & 116.459 & 28 & 308.4 & 46.6 & 5.4 & 26.4 & 10 & \multirow{3}{*}{$\begin{array}{l}\text { All oriented specimens (except } \\
\text { depth interval } 490.0-495.0 \mathrm{~m} \text { ). } \\
\text { Depth } 237.0-241.0 \mathrm{~m} \text {. } \\
\text { Depth } 283.5-289.0 \mathrm{~m} \text {. } \\
\text { Depth } 405.0-409.5 \mathrm{~m} \text {. } \\
\text { Depth } 456.5-462.0 \mathrm{~m} \text {. } \\
\text { Depth } 490.0-495.0 \mathrm{~m} \text {. Core rug } \\
\text { apparently misoriented by } 180 \\
\text { Depth } 490.0-495.0 \mathrm{~m} \text {. Corrected for } \\
\text { apparent } 180^{\circ} \text { error in orientation. }\end{array}$} \\
\hline & & & $\begin{array}{l}6 \\
6 \\
7 \\
9 \\
6\end{array}$ & $\begin{array}{l}302.4 \\
301.1 \\
332.7 \\
299.0 \\
108.5\end{array}$ & $\begin{array}{l}57.5 \\
54.4 \\
44.8 \\
32.5 \\
25.4\end{array}$ & $\begin{array}{l}4.2 \\
3.1 \\
7.0 \\
5.0 \\
6.5\end{array}$ & $\begin{array}{c}255.8 \\
482.3 \\
74.8 \\
108.4 \\
107.2\end{array}$ & $\begin{array}{l}10 \\
10 \\
10 \\
10 \\
10\end{array}$ & \\
\hline & & & 6 & 286.6 & 21.3 & 6.5 & 108.5 & 10 & \\
\hline USW GU-3 & 36.818 & 116.467 & $\begin{array}{c}15 \\
5 \\
4 \\
6\end{array}$ & $\begin{array}{l}308.7 \\
310.6 \\
323.6 \\
301.9\end{array}$ & $\begin{array}{l}50.5 \\
63.2 \\
60.0 \\
32.6\end{array}$ & $\begin{array}{l}7.9 \\
4.0 \\
2.3 \\
5.8\end{array}$ & $\begin{array}{c}24.2 \\
372.2 \\
1655.7 \\
135.2\end{array}$ & $\begin{array}{l}10 \\
10 \\
10 \\
10\end{array}$ & $\begin{array}{l}\text { All orfented specimens. } \\
\text { Depth } 162.0-164.5 \mathrm{~m} \text {. } \\
\text { Depth } 214.5-216.5 \mathrm{~m} \text {. } \\
\text { Depth } 356.0-360.0 \mathrm{~m} \text {. }\end{array}$ \\
\hline USW H-1 & 36.866 & 116.453 & 12 & 320.7 & 51.8 & 1.6 & 693.4 & 10 & Depth $136.5-144.0 \mathrm{~m}$. \\
\hline UE25a-4 & 36.860 & 116.448 & 16 & 301.2 & 45.1 & 3.2 & 130.0 & 20 & Deoth $112.0-151.5 \mathrm{~m}$. \\
\hline UE25a-5 & 36.857 & 116.445 & 16 & 290.3 & 54.0 & 1.6 & 504.2 & 20 & Depth 85.0-129.5 m. \\
\hline UE25a-6 & 36.854 & 116.446 & 12 & 335.3 & 52.7 & 5.1 & 73.6 & 20 & Depth 85.5-122.0 m. \\
\hline UE 25a-7 & 36.855 & 116.453 & 12 & 301.1 & 46.2 & 4.3 & 102.7 & 20 & Depth 114.0-146.0 m. \\
\hline
\end{tabular}

For explanation of headings see Table 1. 


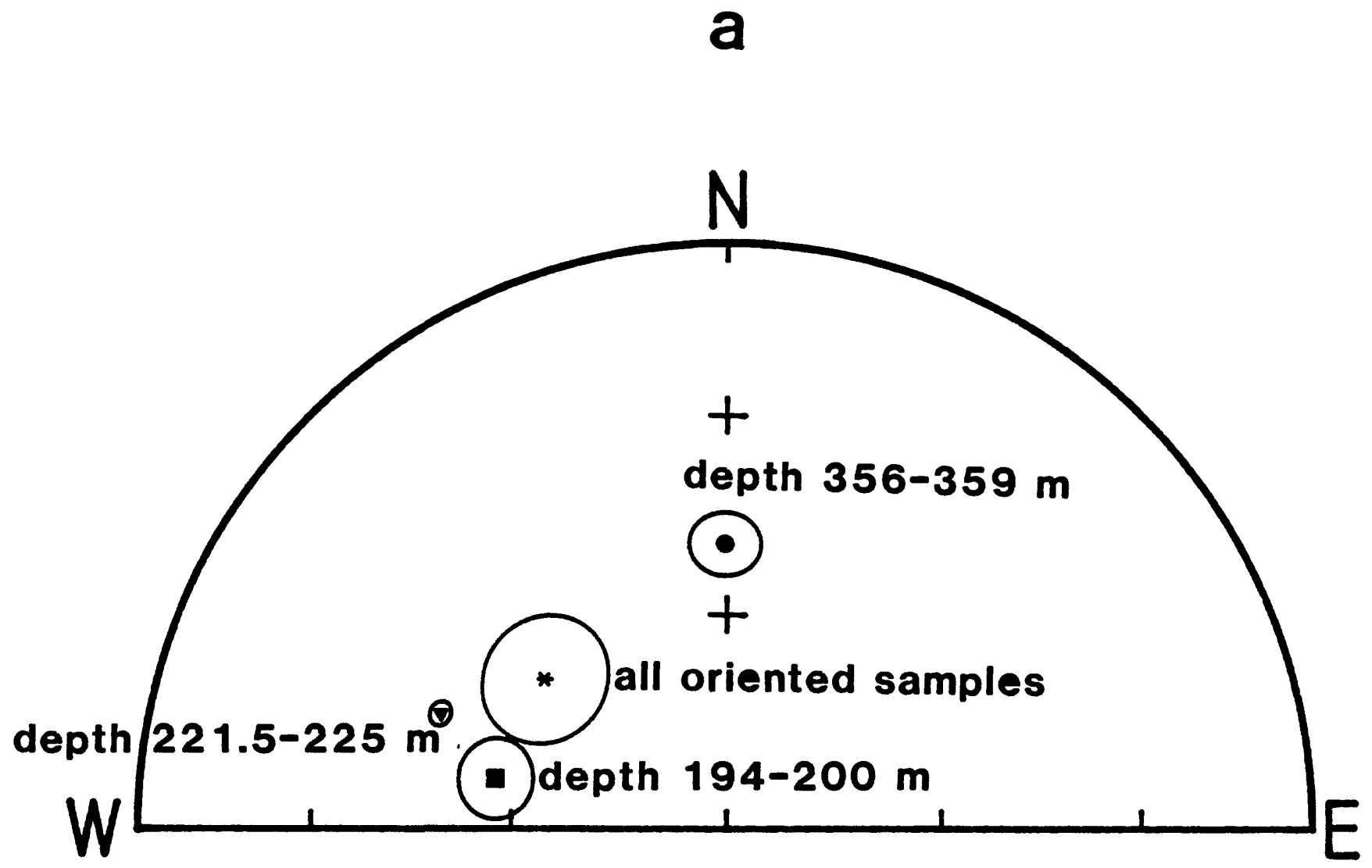

Figure 6.--Equal area projection of paleomagnetic data and associated cones of 95\% confidence for the Topopah Spring Member of the Paintbrush Tuff (see Table 7): a) Drill hole USW G-1; b) Drill hole USW G-2; c) Drill Hole USW G-3; d) Dril1 holes UE25a-4, $-5,-6,-7$, and USW H-1; e) Outcrop sampling localities. 
b

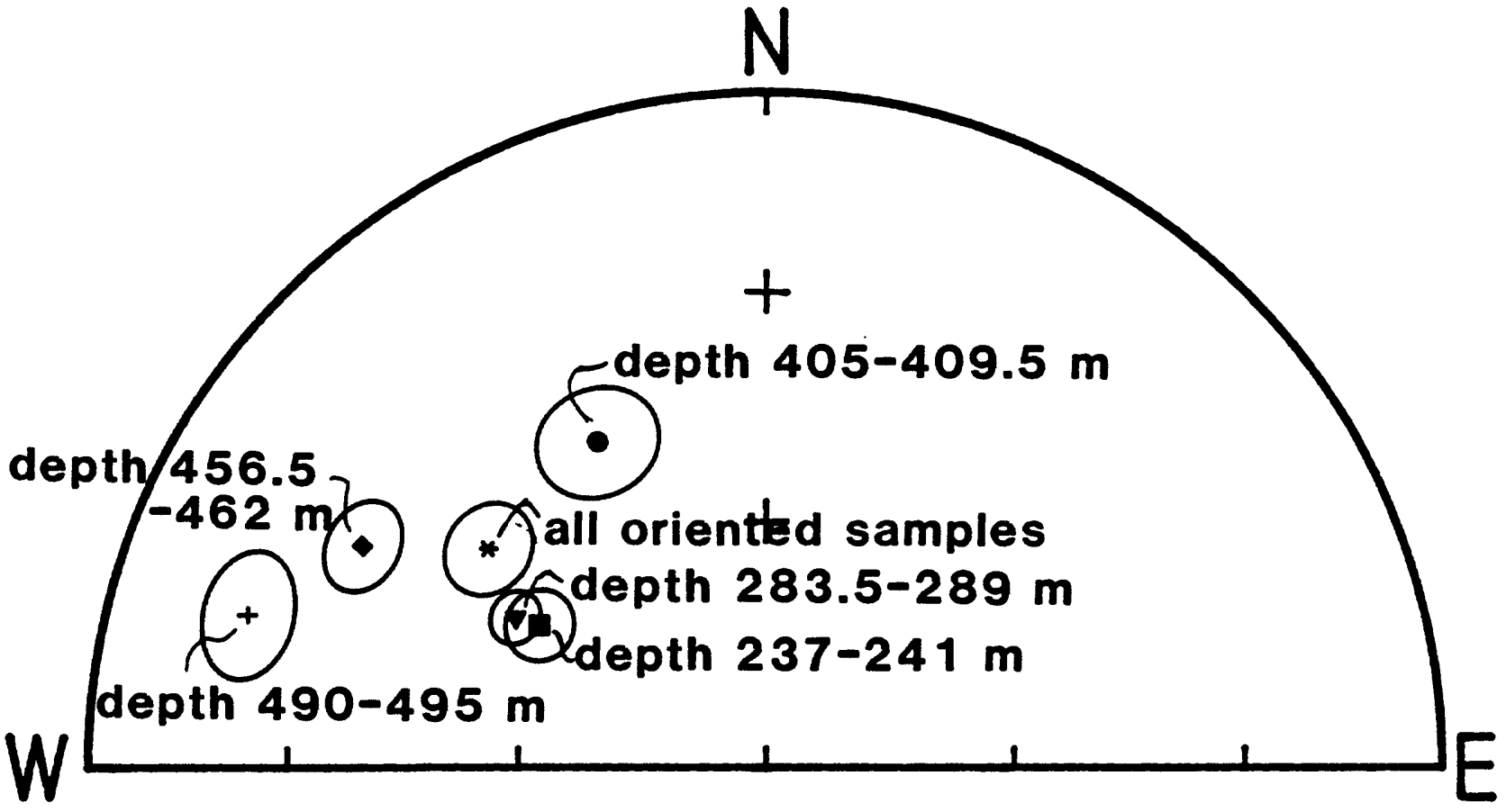

Figure 6.--continued 


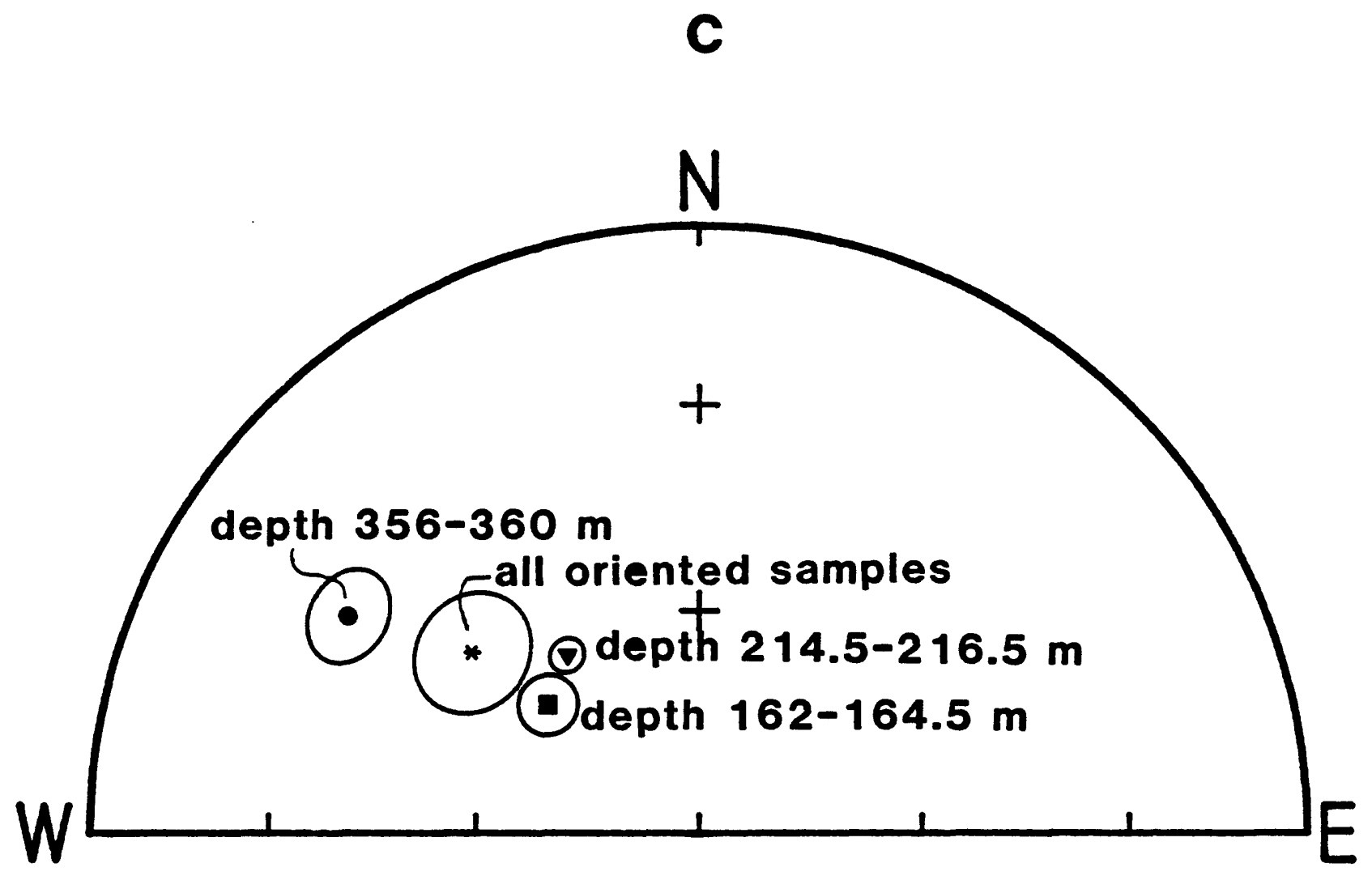

Figure 6.-continued 


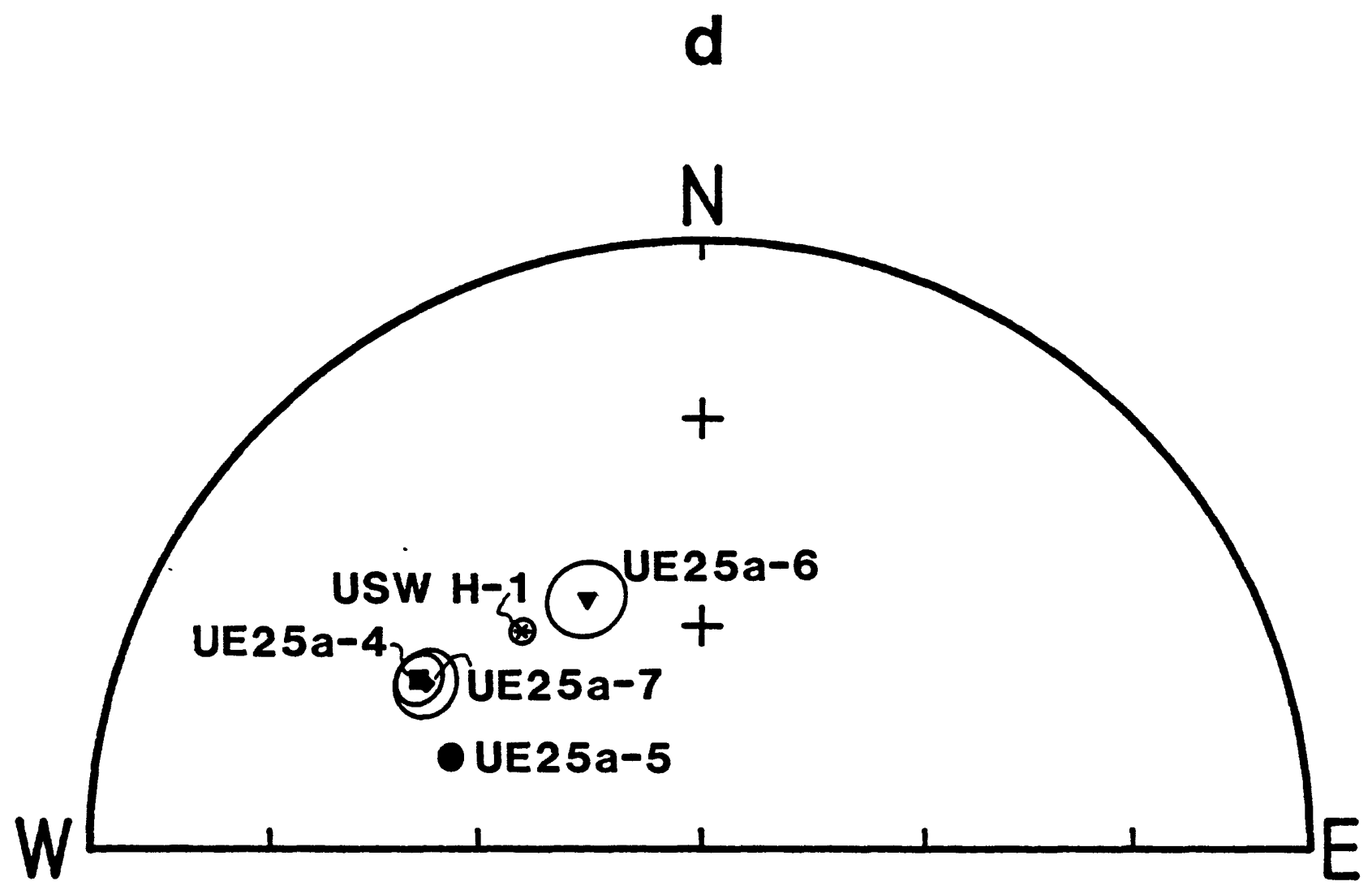

Figure 6.-continued 


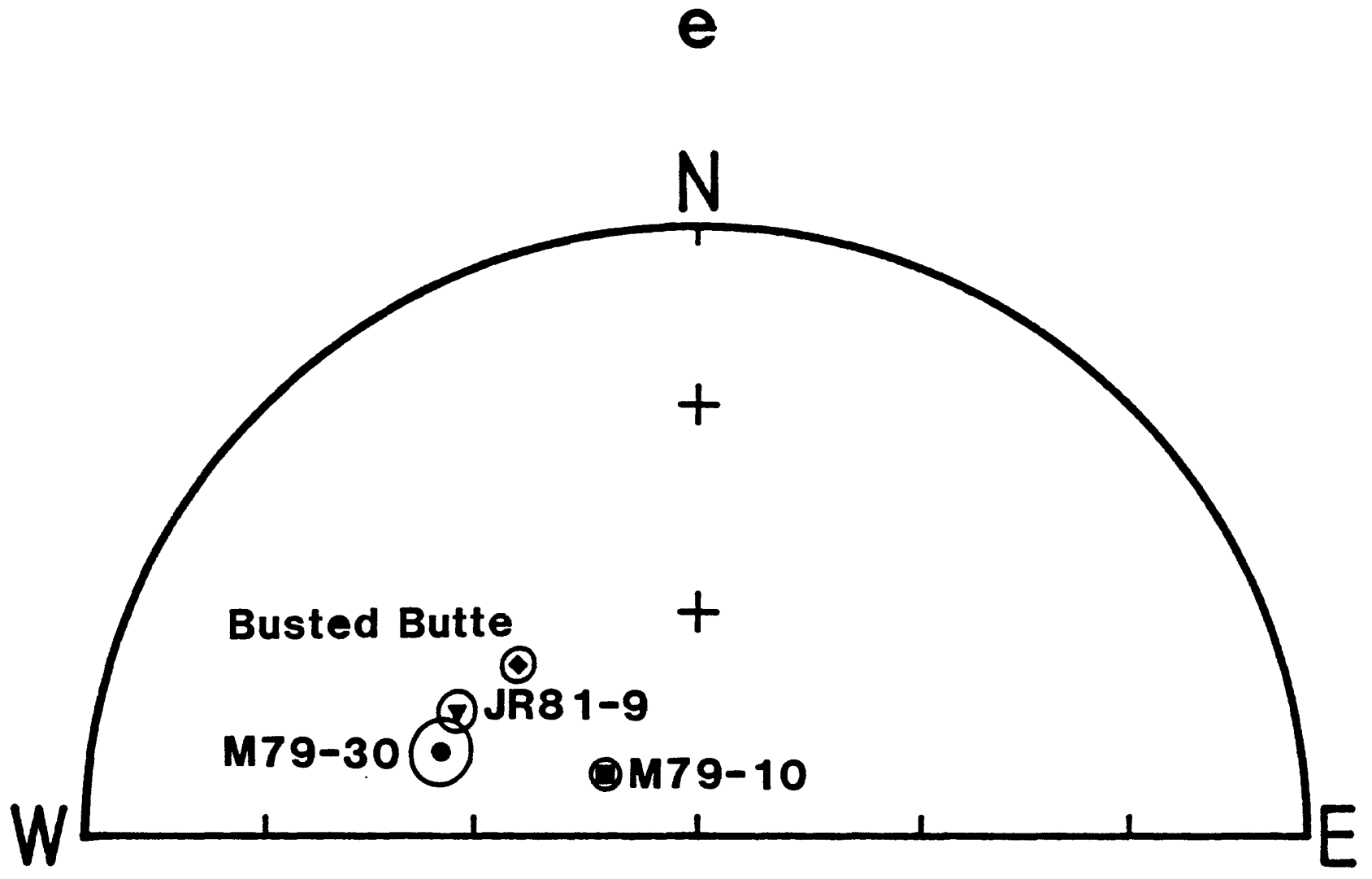

Figure 6.-continued 


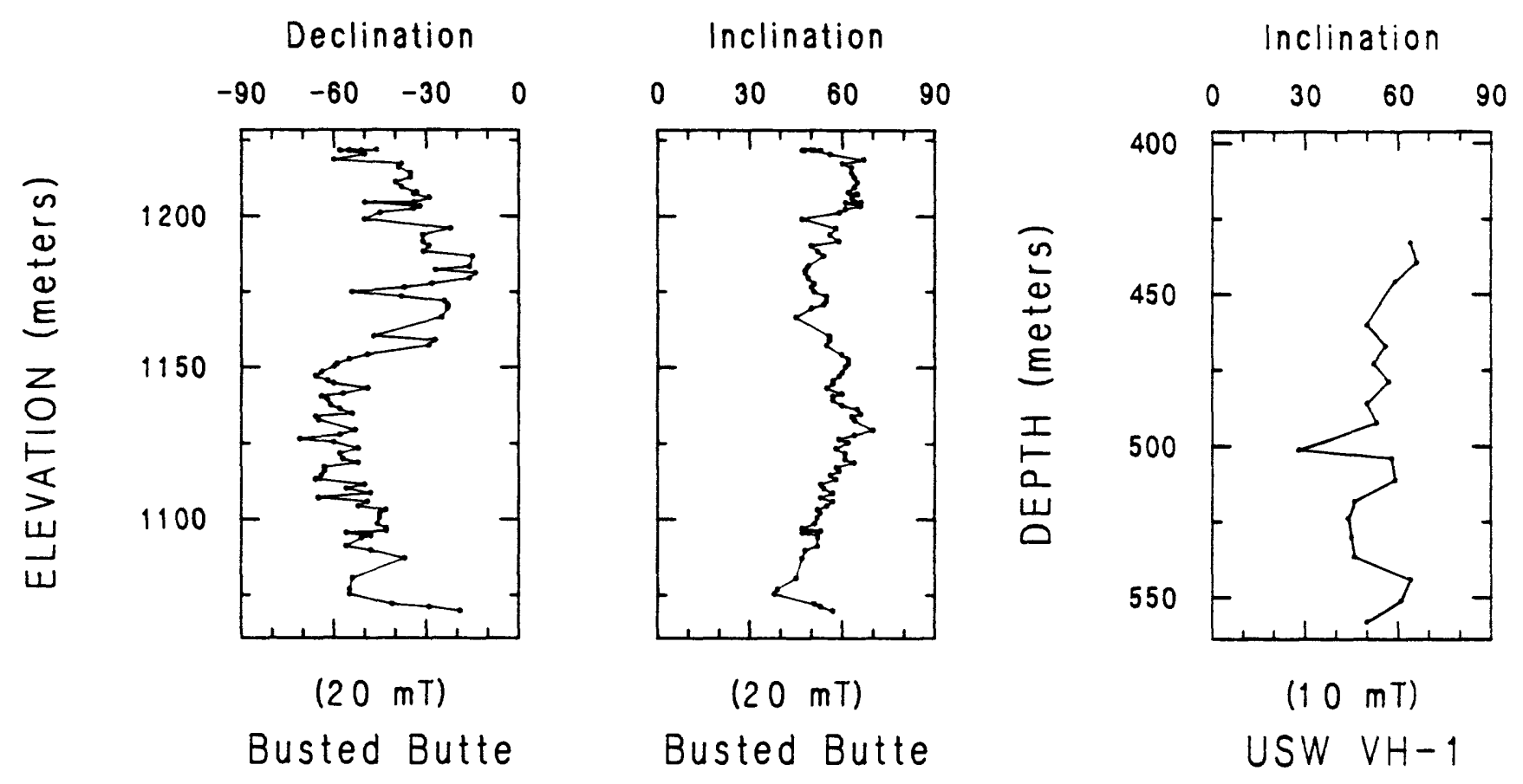

Figure 7.-Paleomagnetic data versus depth for the Topopah Spring Member of the Paintbrush Tuff; inclinations and declinations from Busted Butte after af demagnetization at a peak field of $20 \mathrm{mT}$, and inclinations 


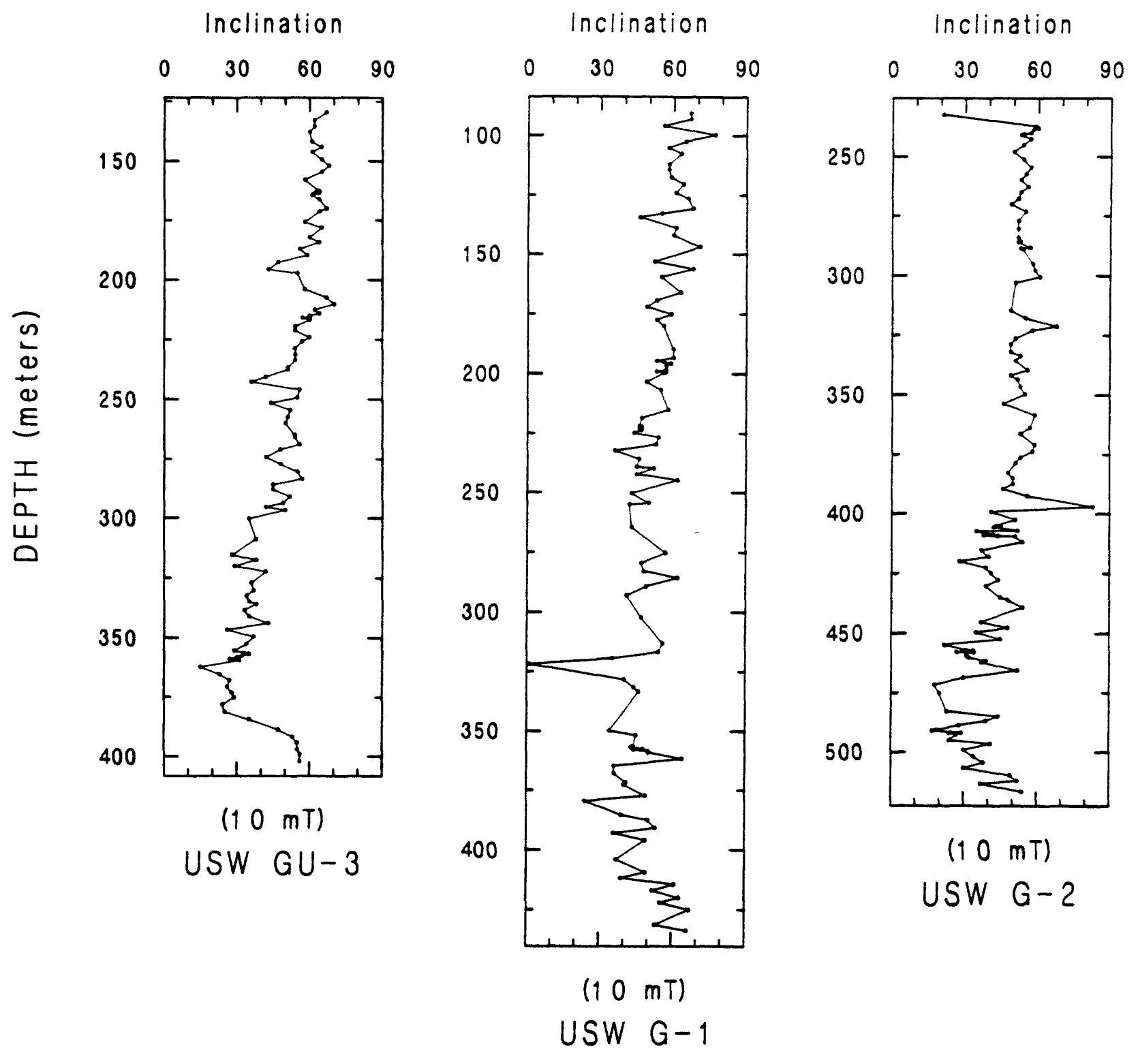

from drill hole USW VH-1, GU-3, G-1, and G-2 after af demagnetization at a peak field of $10 \mathrm{mT}$. Elevations for the Busted Butte locality were obtalned by hand leveling. 
Magnetization and susceptibility data for the Topopah Spring Member were obtained from throughout the unit from drill holes USW G-1, G-2, and GU-3 and from outcrop at Busted Butte. In addition the lower part of the unit was sampled from drill hole USW VH-1 (Figure 8 and Table 8). Both remanent intensity and susceptibility display large changes with depth. In some parts of the sampled sections there appears to be a high degee of correlation between these parameters; for example, between about 285 and $390 \mathrm{~m}$ in USW G-1, intensity and susceptibility change in a very similar manner. In other cases, such as throughout the entire section at Busted Butte and at USW GU-3, there appears to be little if any correlation between changes in susceptibility and intensity.

The only obvious correspondence between magnetic properties and gross 1 ithology [Spengler and others, 1981; Maldonado and Koether, 1983; Scott and Castellanos, 1984] is that the basal vitrophyre correlates with a relative susceptibility minimum (vitrophyre extends between depths of about 392-409 m, 498-509 m, and 362-387 $\mathrm{m}$ in USW G-1, G-2 and GU-3, respectively; and between elevations of about 1090 and $1078 \mathrm{~m}$ at Busted Butte). In general the intensity of magnetization increases gradually with depth to the vicinity of the basal vitrophyre and then decreases sharply. Superimposed on this general trend are a number of relative maxima and minima. At Busted Butte a relative intensity maximum occurs in the basal vitrophyre. This is similar to the occurrence of an intensity peak in the basal vitrophyre of the Tiva Canyon Member in drill hole USW GU-3 (Figure 4). However, pronounced intensity maxima do not occur in the basal vitrophyre from the drill holes. In these localities the vitrophyre occurs in the zone of decreasing intensity near the base of the unit.

The reasons for the changes in magnetization and susceptibility are unknown but are probably a combination of (1) concentration of magnetite either by settling in the magma chamber or during emplacement of an ash flow, (2) post-emplacement growth of magnetic phases, and (3) oxidation of magnetite either during cooling or at low temperature. Until much more closely spaced vertical sections can be sampled, meaningful correlation of features within the sections is impossible. 


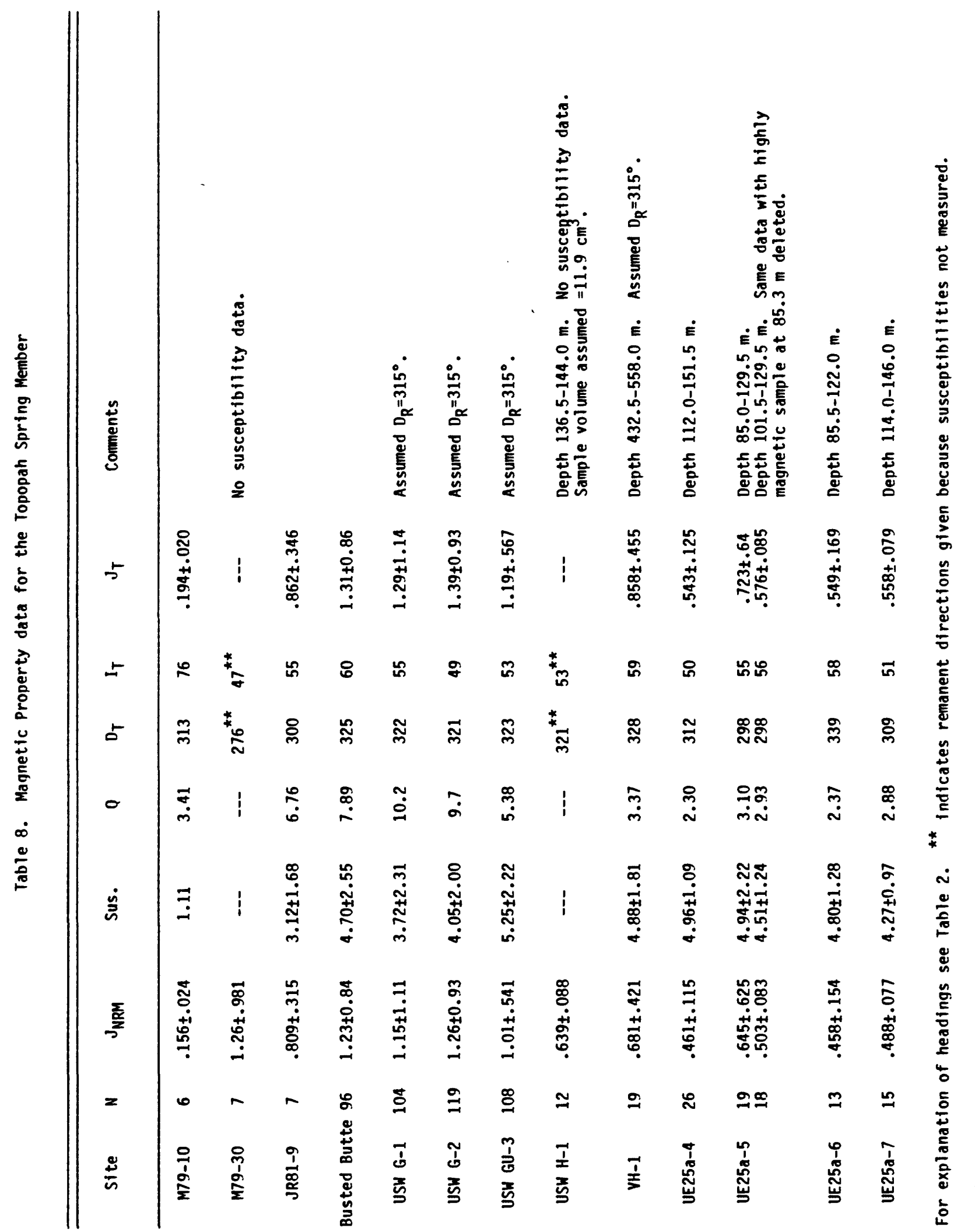



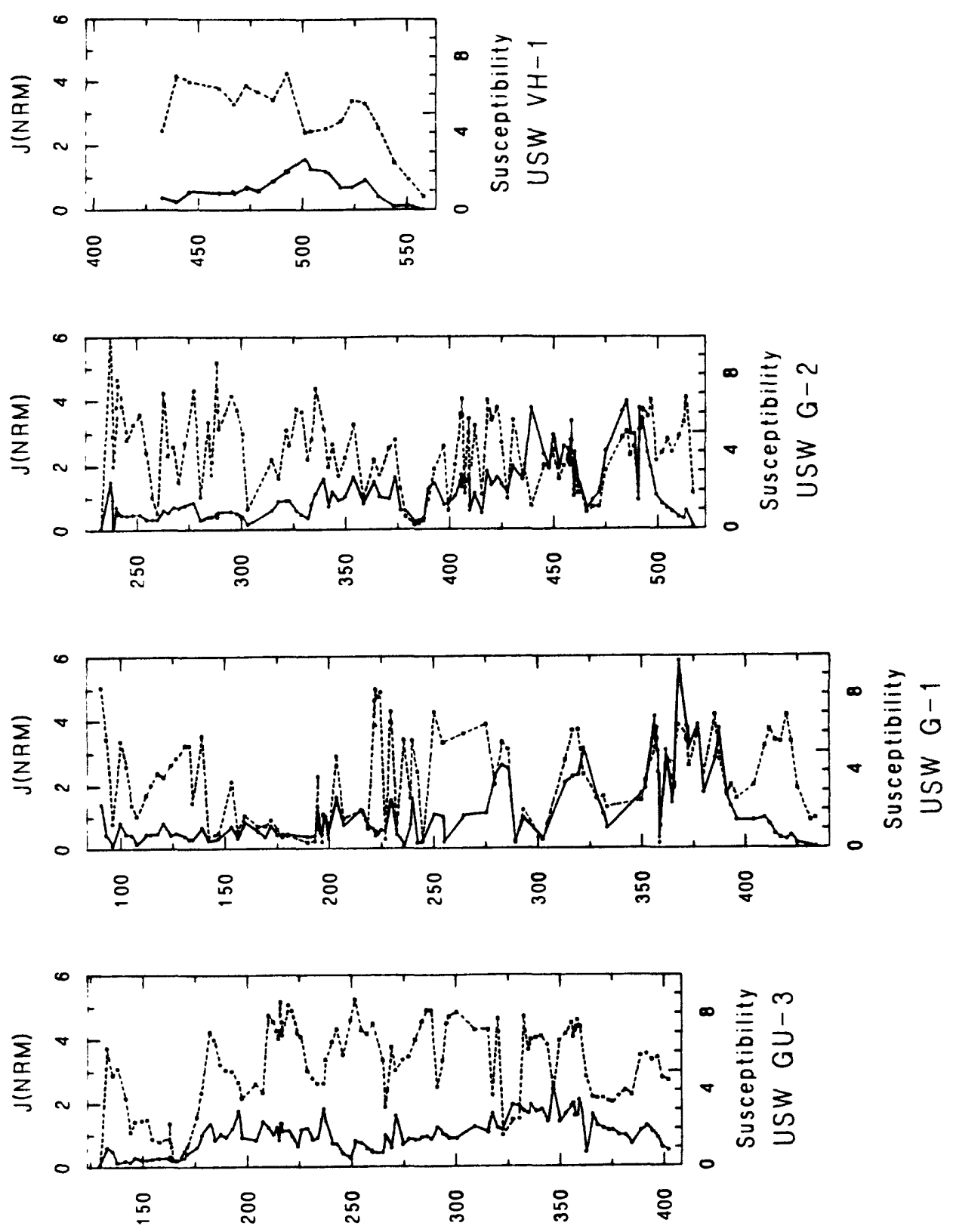

(s)วเวس) $H \perp d \exists O$

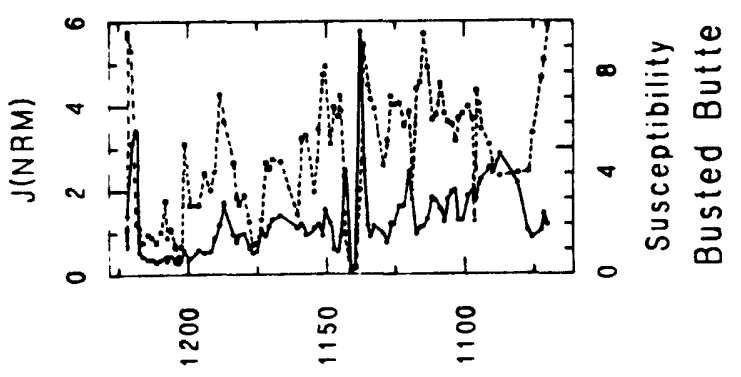

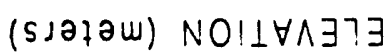

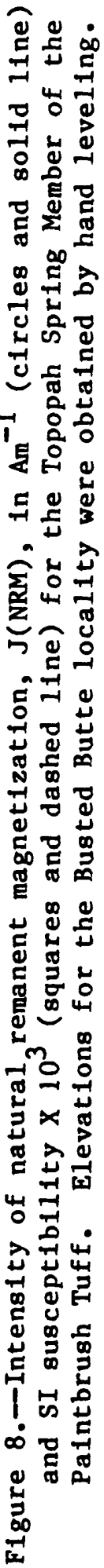




\section{Tuffaceous beds of Calico Hills}

The tuffaceous beds of Calico Hills, a sequence of ash-flow tuffs and thin reworked tuffs, was sampled in drill holes USW G-1 and G-2. The only oriented specimens were obtained from a depth interval between 466.5 and 468.5 $m$ in USW G-1 near the base of a $34.5 \mathrm{~m}$ thick ash-flow tuff [Spengler and others, 1981]. After af demagnetization to $20 \mathrm{mT}$ these samples yield a mean direction of $D=337.1^{\circ}, I=67.5^{\circ}(\propto 95=10.7, K=39.9)$.

The inclination data are quite noisy, with many of the spikes being within reworked tuff intervals and the margins of various ash-flow tuffs. Nevertheless, inclination data from both USW G-1 and $G_{A}-2$ show consistent patterns (Figure 9). Inclinations increase from about $40^{\circ}$ in the lowermost ash-flow tuff in USW G-1 (base of this tuff is at a depth of about $529 \mathrm{~m}$ ) to values of about $70^{\circ}$ near the top of the Calico Hills at this locality. Inclinations from the basal ash-flow tuff in USW G-2 are also about $40^{\circ}$. Remanent directions then steepen to about $70^{\circ}$ (or more) in the depth interval $720-775 \mathrm{~m}$, and then flatten with decreasing depth to about $30^{\circ}$ in the upper part of the unit. These patterns suggest that the ash-flow tuffs which comprise the Calico Hills were erupted over a long period relative to changes in the direction of the earth's magnetic field (secular variation). These patterns also indicate that the section present in drill hole USW G-1 is correlative with no more than the lowermost $100-125 \mathrm{~m}$ of the section encountered in USW G-2.

The ash-flow and bedded tuffs of the Calico Hills, sampled in drill holes USW $G-1$ and $G-2$, have maximum intensities of remanent magnetization of about $0.5 \mathrm{Am}^{-1}$ and average intensities of about $0.1 \mathrm{Am}^{-1}$ or less (Figure 10 and Table 9).

In the Calico Hills from USW G-1 the highest values of magnetization and relatively high values of susceptibility occur in samples from a single ash-flow tuff which extends from a depth of 479 to $516 \mathrm{~m}$ (Spengler and others, 1981). In addition, a large susceptibility peak occurs in the tuffaceous sandstone which makes up the bottom $20 \mathrm{~m}$ of the unit at this locality.

The uppermost $75 \mathrm{~m}$ of the Calico Hills from drill hole USW G-2 contains magnetization and susceptibility maxima with peak values similar to those in the central part of the unit at USW G-1 (Figure 10). However, the upper $75 \mathrm{~m}$ of the unit from USW G-2 comprises five ash flows each less than $16 \mathrm{~m}$ in thickness, while the maxima from USW G-1 occur in a single flow about $37 \mathrm{~m}$ thick (Spengler and others, 1981; Maldonado and Koether, 1983). If the proposed correlation (based on paleomagnetic inclinations) between these two sections is correct, then the $37 \mathrm{~m}$ thick, relatively magnetic tuff from USW G-1 can correspond to nothing above a depth of $785 \mathrm{~m}$ in USW G-2. Possibly this ash-flow tuff in USW G-1 corresponds to a lower part of the Calico Hills section which has been removed by faulting at USW G-2 [Maldonado and Koether, 1983]. 


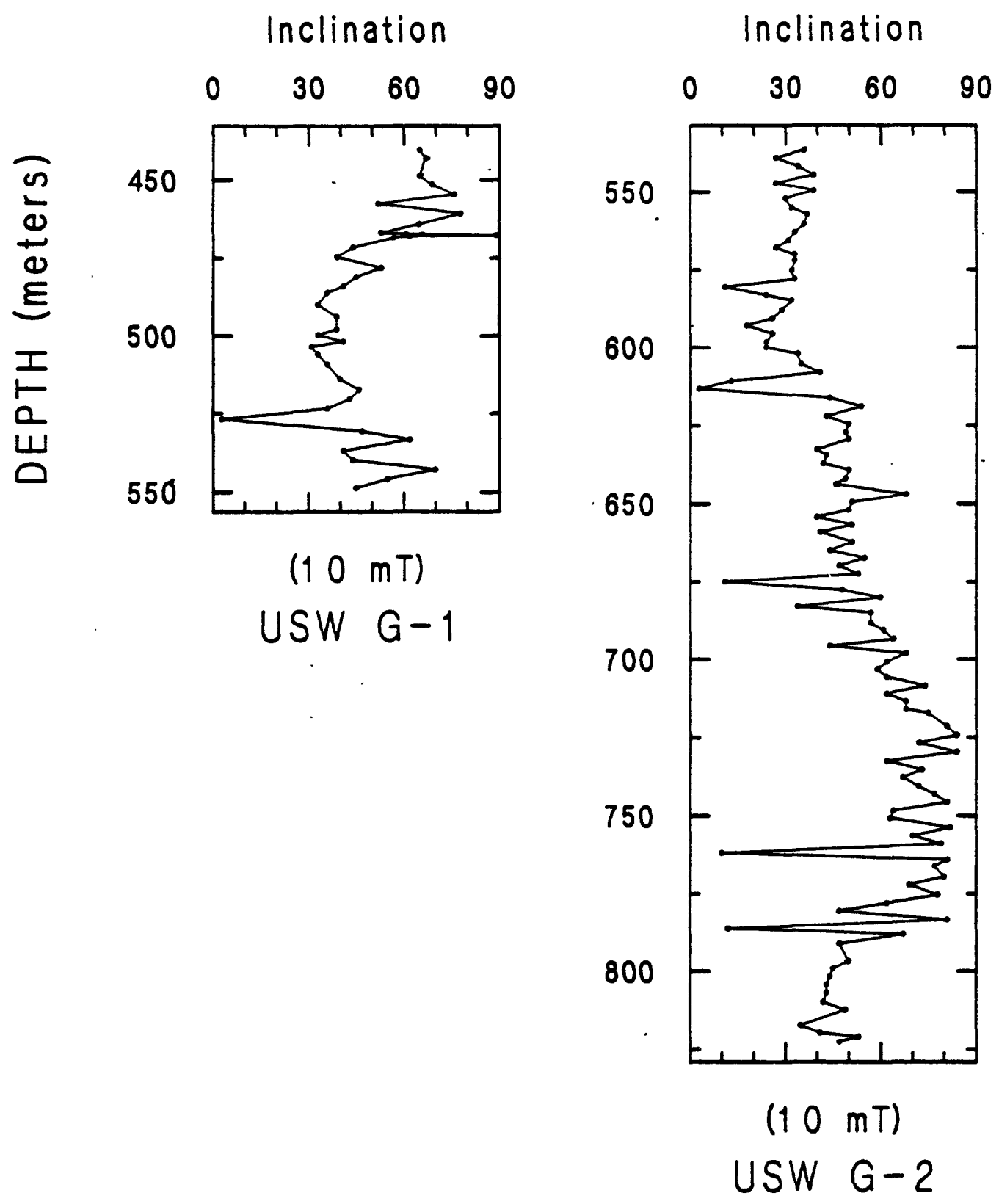

Figure 9.--Paleomagnetic inclinations versus depth for the tuffaceous beds of Calico Hills after af demagnetization at a peak field of $10 \mathrm{mT}$. 


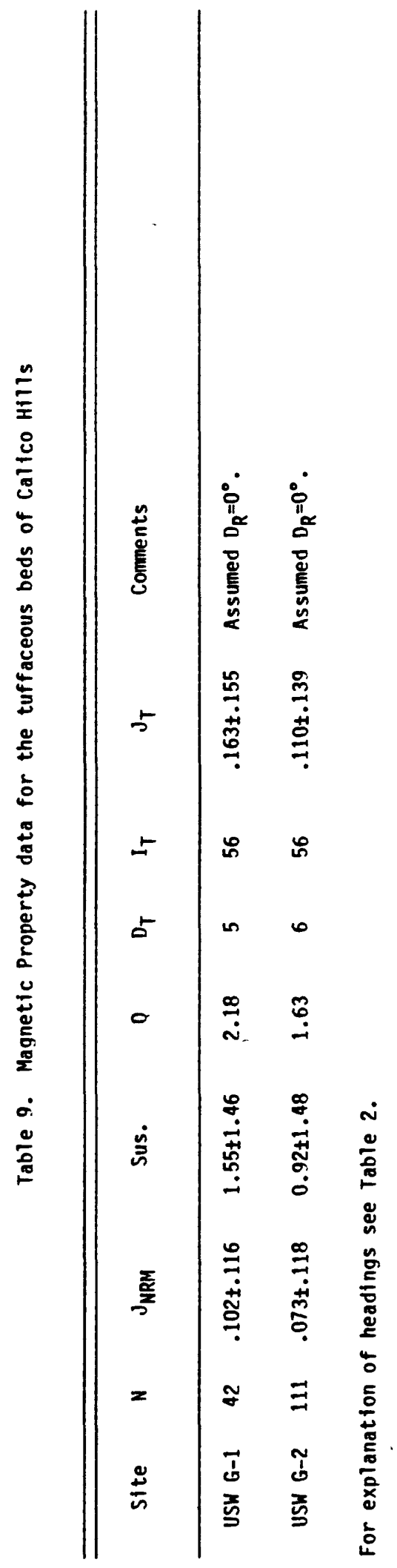




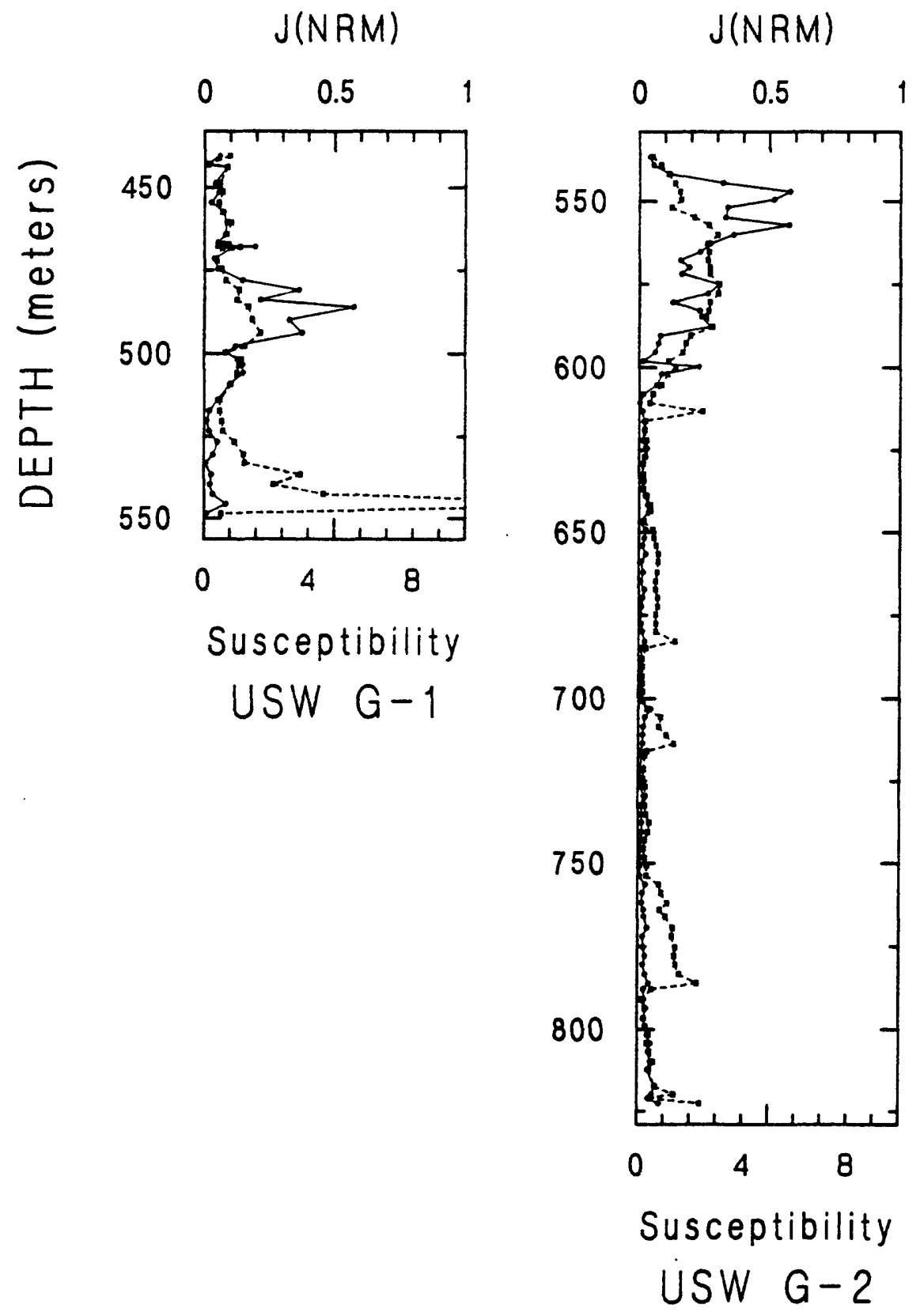

Figure 10.- Intensity of natural remanent magnetization, $\mathrm{J}(\mathrm{NRM})$, in $\mathrm{Am}^{-1}$ (circles and solid 1ine) and SI susceptibility $X 10^{3}$ (squares and dashed 1ine) for the Tuffaceous Beds of Calico Hills. 


\section{Crater Flat Tuff}

Prow Pass Member: The Prow Pass Member was sampled in drill holes USW G-1, G-2, GU-3 and VH-1. Mean remanent directions from the three depth intervals from which oriented core was obtained in drill hole USW G-1 differ significantly (Figure 11 and Table 10). One of these depth intervals falls in each of three subunits of the Prow Pass [Spengler and others, 1981]. Therefore it is possible that the directional variation is due to movement of the magnetic field between the times of emplacement of these subunits. However, since differences in the inclinations of the mean directions are small it is also possible that the apparent directional changes are due to misorientation of the core segments. Samples from the single depth intervals from which oriented core was obtained in USW G-2 and GU-3 yield mean remanent directions which nearly coincide with that from the 616.5-622.0 $\mathrm{m}$ interval in USW G-1 (Figure 11).

No large consistent changes in inclination are observed with depth (Figure 12). Three samples from USW G-1 yield apparently aberrant directions. These are the uppermost sample collected and samples at depths of $604.7 \mathrm{~m}(1883.5 \mathrm{ft})$ and $607.8 \mathrm{~m}(1893.5 \mathrm{ft})$ which fall just above and just below the contact between the upper and middle units of the Prow Pass. These high and low inclinations may be due to remagnetization during alteration of the tuff in these zones. Similarly, the highly variable inclination record below about $930 \mathrm{~m}$ in USW G-2 occurs in a subunit which is intensely altered (zeolitized and silicified) [Maldonado and Koether, 1983].

The remanent intensity of the Prow Pass Member averages a few tenths of an ampere per meter at three of the localities at which it was sampled (Figure 13 and Table 11). At the fourth, drill hole USW G-2, the average remament intensity is less than $0.1 \mathrm{Am}^{-1}$. There is a general similarity in the patterns of intensity and susceptibility changes with depth between drill hole USW G-1 and GU-3. The uppermost part of the unit at these localities is characterized by relatively high intensities (including the only values greater than $1 \mathrm{Am}^{-1}$ ) and susceptibilities. Values for both of these parameters decrease with depth; still deeper susceptibility increases while magnetization remains quite low. The variations of magnetization and susceptibility with depth observed in the section of the Prow Pass sampled in drill hole USW VH-1 are similar to the uppermost portions of those from USW G-1 and GU-3.

The intensity and susceptibility curves determined for USW G-2 bear little resemblance to those from USW G-1 and GU-3. This can be attributed to two reasons. First, the uppermost portion of the Prow Pass has been faulted out at the USW G-2 locality, and second the rock at this location (especially in the lower part of the unit) is highly altered by zeolitization and silicification [Maldonado and Koether, 1983]. During the alteration process magnetite was probably oxidized to less magnetic hematite. This would account for the very low remanent intensities observed throughout the Prow Pass Member at this location. 


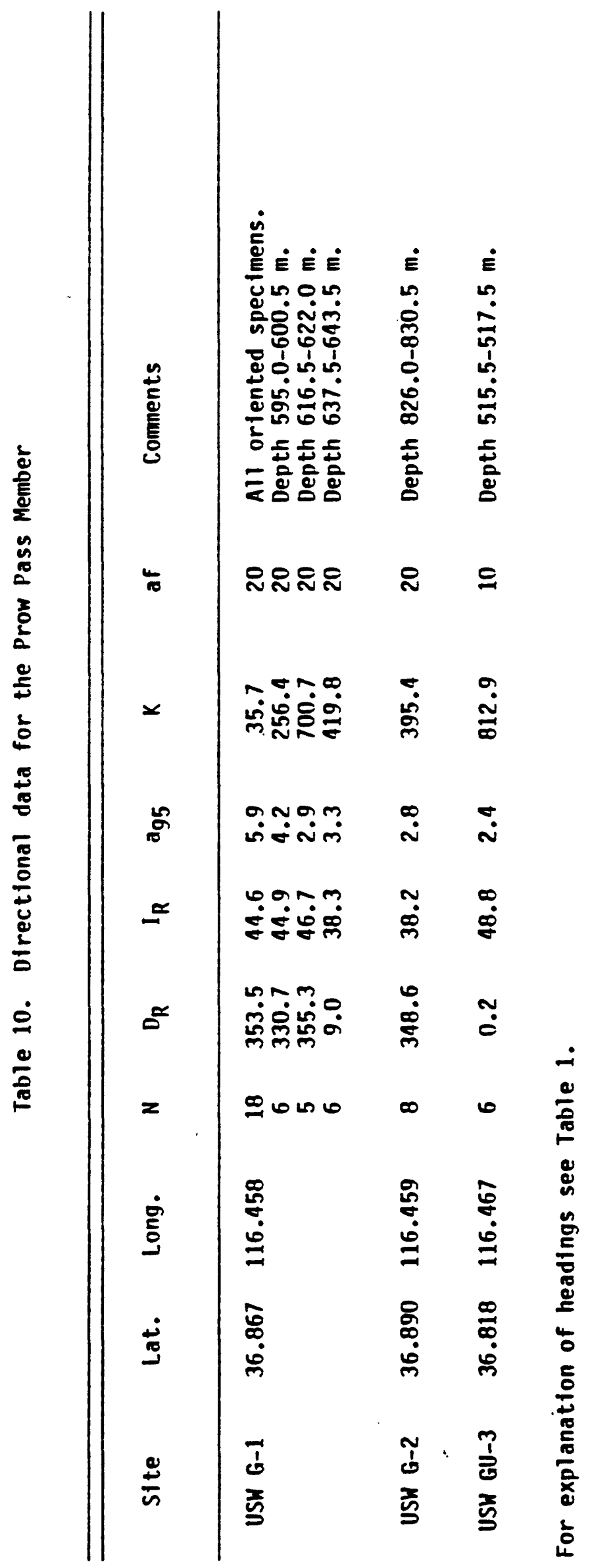




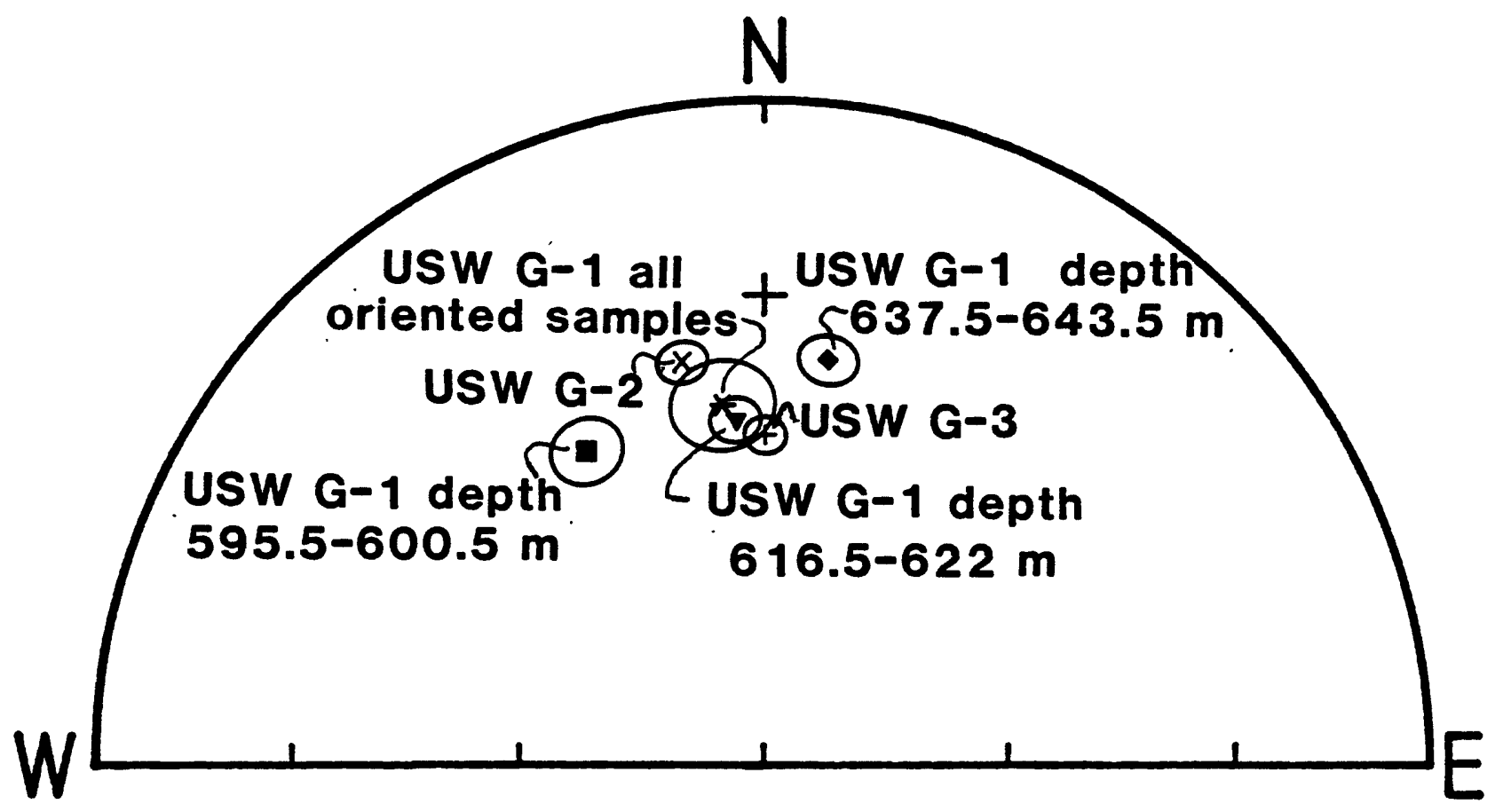

Figure 11.-Equal area projection of mean paleomagnetic directions and associated cones of $95 \%$ confidence for the Prow Pass Member of the Crater Flat Tuff (see Table 10). 

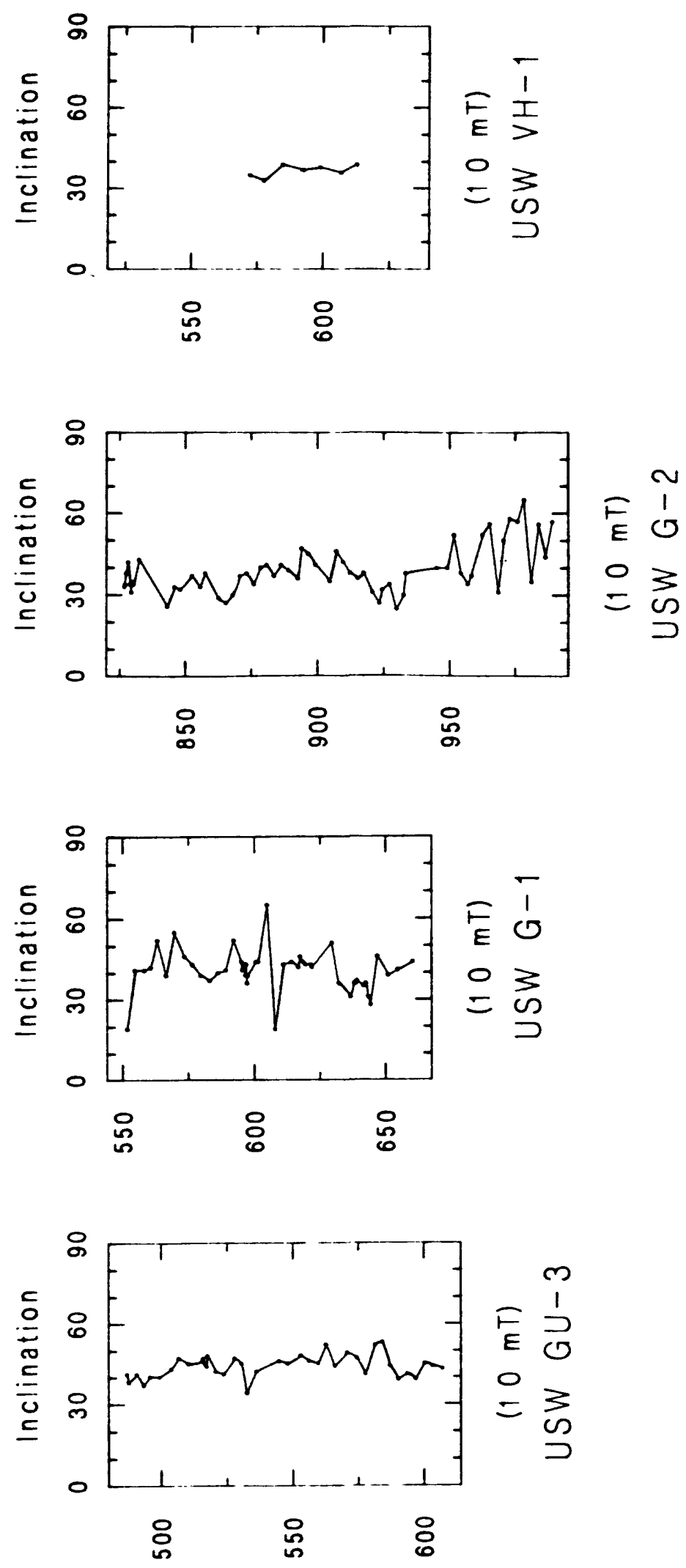

(s」әғวس) $H \perp d \exists O$ 


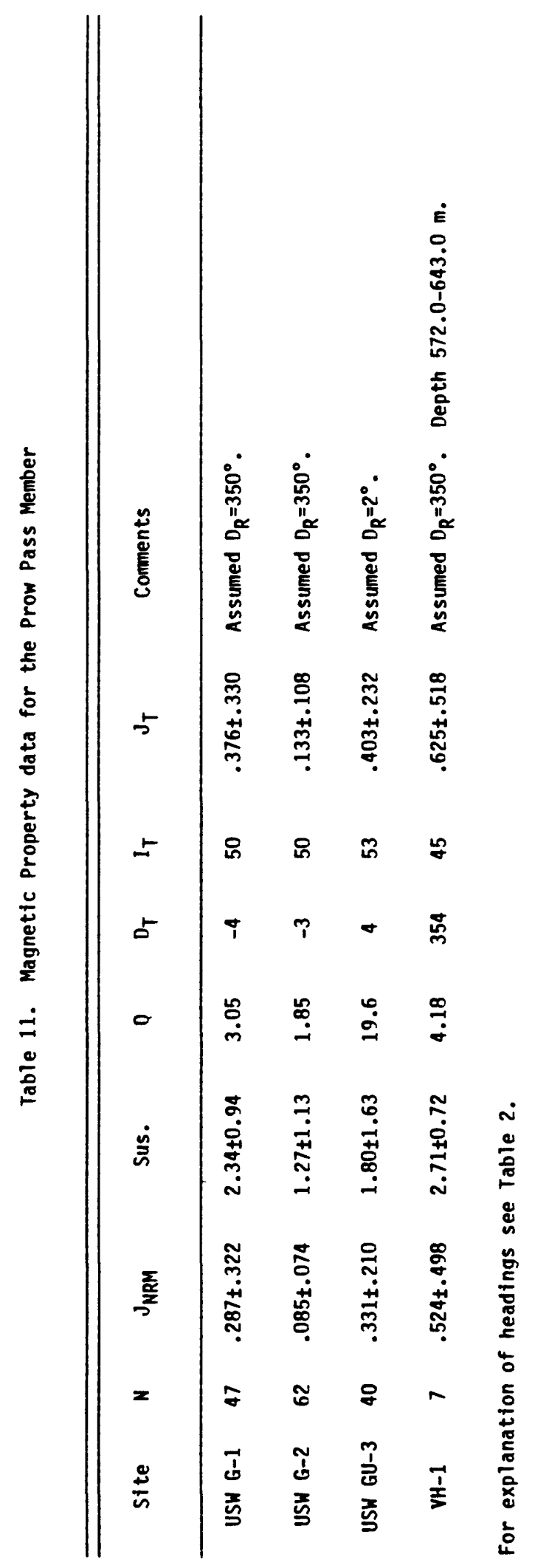



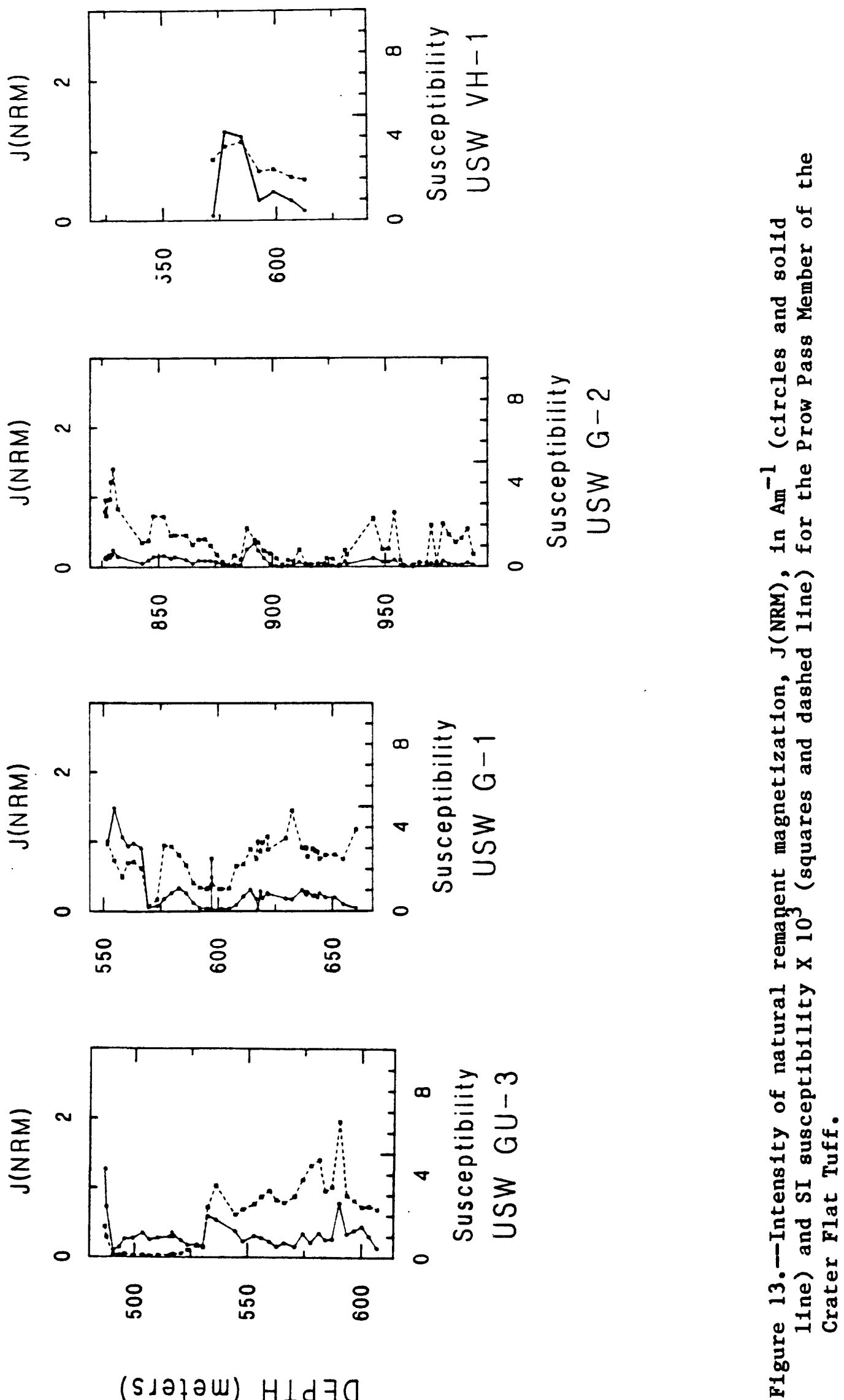

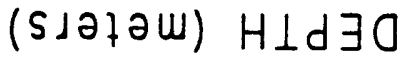


Bullfrog Member: Oriented samples were obtained from one surface locality and dritT holes USW G-1, G-2 and GU-3. Mean remanent directions from USW G-1 and GU-3 fall near that from the outcrop site (Figure 14 and Table 12). The mean direction from G-2 lies significantly to the west. Although this could be due to a tectonic rotation, or a number of other causes, perhaps the most likely explanation is an error in the orientation data.

Inclination data from drill holes USW GU-3 and VH-1 are quite uniform throughout (Figure 15). In contrast, data from IISW G-2 contain relatively high inclinations near the top of the unit which may be due to alteration of the tuff in this zone. Data from USW G-1 contains two zones of extremely low inclination at about $700 \mathrm{~m}$ and $780 \mathrm{~m}$. The $10 \mathrm{w}$ near $700 \mathrm{~m}$ occurs near a shear fracture [Spengler and others, 1981] and could be attributed to either rotation of rock in response to movement on the fault or to remagnetization of the rock due to alteration of the magnetic phases by fluids moving along the fracture. Similarly, the low at about $780 \mathrm{~m}$ occurs in a zone of fracturing.

A high degree of similarity exists between the patterns of intensity and susceptibility variation in the Bullfrog Member from drill holes USW GU-3 and VH-1 (Figure 16). Both intensity and susceptibility at these two localities define: (1) a broad minimum at a depth of about $625 \mathrm{~m}$ in USW GU-3 and $640 \mathrm{~m}$ in VH-1; (2) a maximum at about $650 \mathrm{~m}$ in USW GU-3 and $675 \mathrm{~m}$ in VH-1; and (3) a sharp minimum at 660-665 $\mathrm{m}$ in USW GU-3 and $690 \mathrm{~m}$ in VH-1. Below this the susçeptibility increases and remains relatively high (mostly between 5 and $7 x$ $10^{-3} \mathrm{SI}$ ) to the bottom of the moderately to densely welded portion of the unit at about $765 \mathrm{~m}$ in USW GU-3 [Scott and Castellanos, 1984] and to the bottom of drill hole USW VH-1. In USW GU-3 the remanent intensity curve increases below $665 \mathrm{~m}$ and contains a number of well defined peaks in the moderately to densely welded interior of the unit. Intensities also increase in the lower portion of the core from USW VH-1 but do not approach the amplitude of those from USW GU-3.

of particular interest is a minimum in both magnetization and susceptibility at $777 \mathrm{~m}$ in USW GU-3. These minima coincide with a cooling break recognized by Scott and Castellanos [1984] on the basis of a minimum in the degree of welding and the presence of nearly a meter of bedded tuff. Similar minima in magnetization and intensity are associated with depositional breaks in the Tram Member (see below).

The average remanent intensity of the Bullfrog Member from drill hole USW G-1 is much less than that from either USW GU-3 or VH-1 (Table 13). In addition, the distinctive variations observed near the top of the unit at these latter localities are not present in the record from USW G-1. At this locality intensities gradually decrease while susceptibilities increase with depth in the upper $75 \mathrm{~m}$ of the unit. Below about $740 \mathrm{~m}$ both intensity and susceptibility increase to a maximum near the base of the moderately to densely welded portion of the flow [Spengler and others, 1981] and then fall as the degree of welding decreases near the base of the unit.

The entire thickness of the Bullfrog Member is highly altered at drill hole USW G-2 [Maldonado and Koether, 1983] and both remanent intensity and susceptibility are characterized by low values at this locality. 


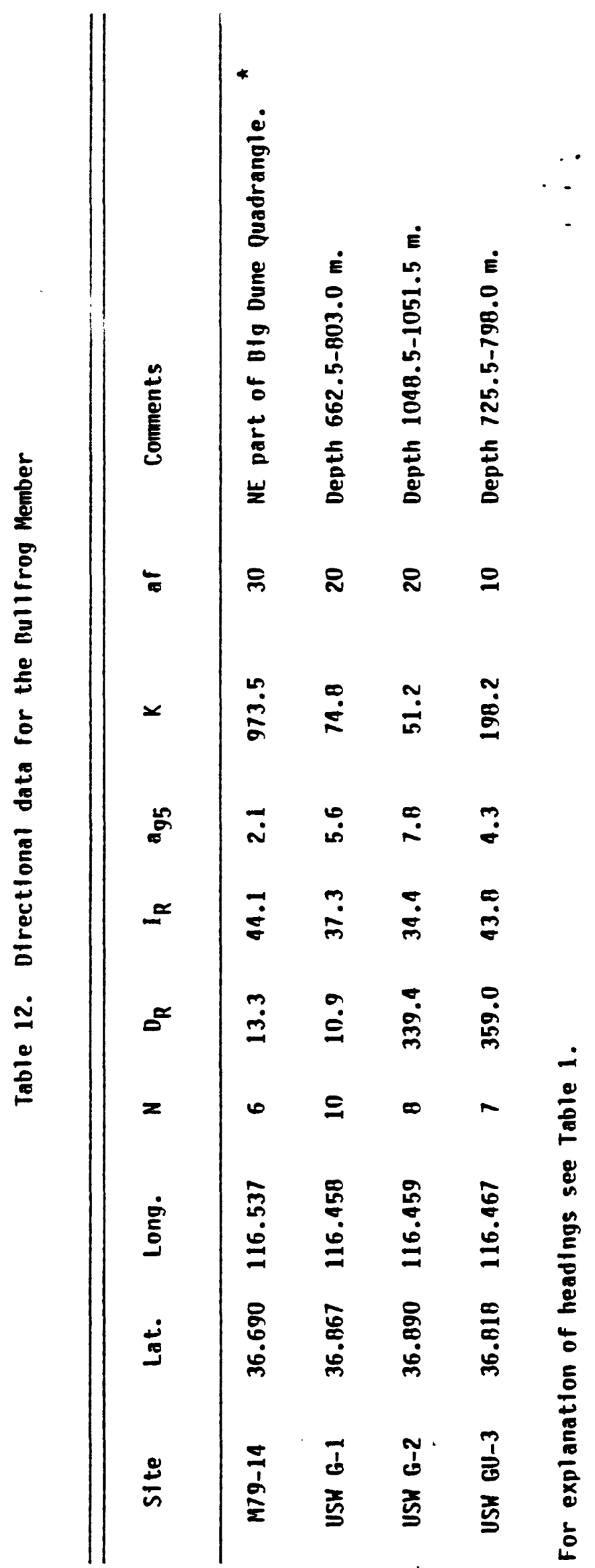




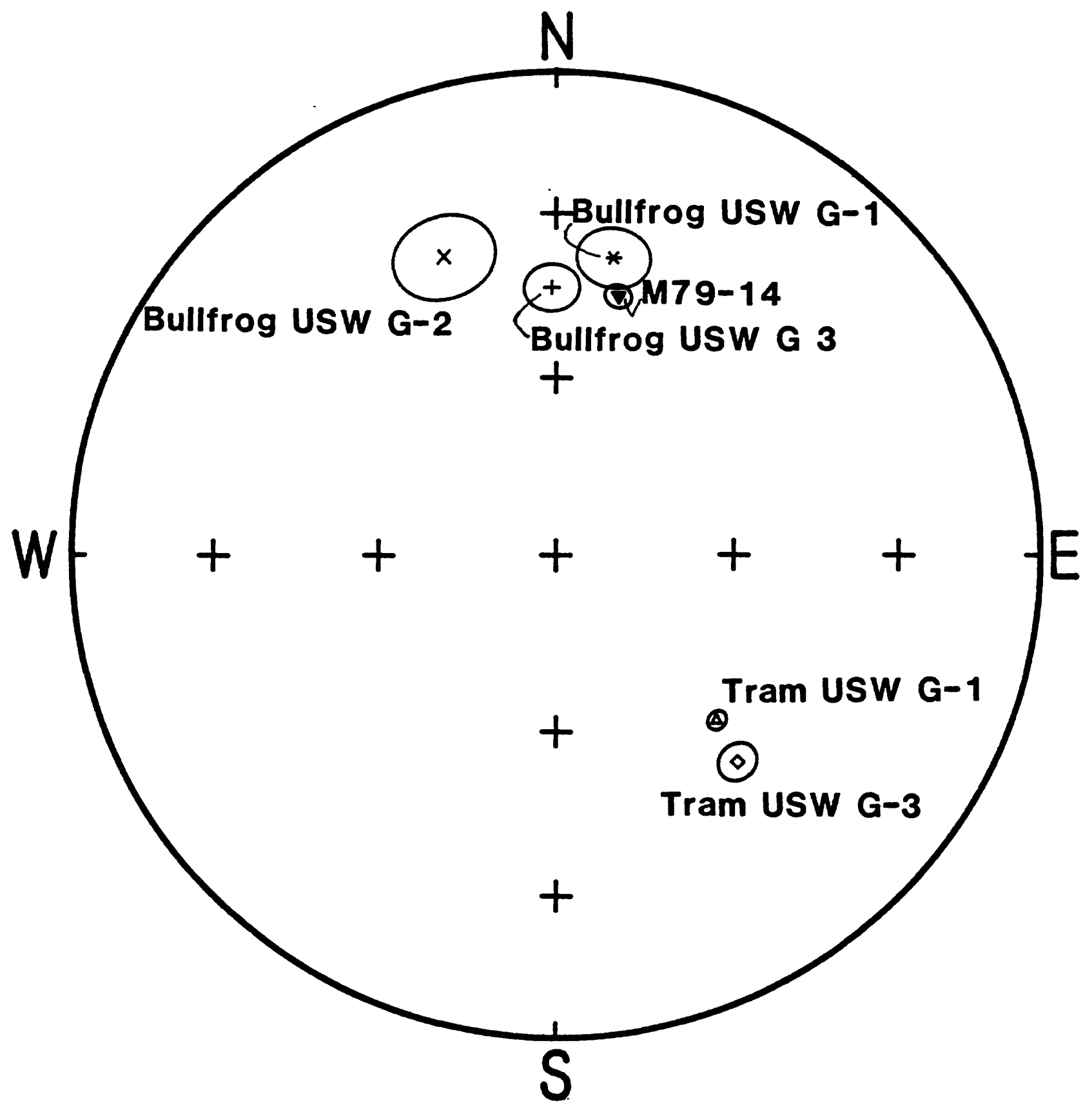

Figure 14.-Equal area projection of mean paleomagnetic directions and associated cones of $95 \%$ confidence for the Bullfrog and Tram Members of the Crater Flat Tuff (see Table 12 and 14). 

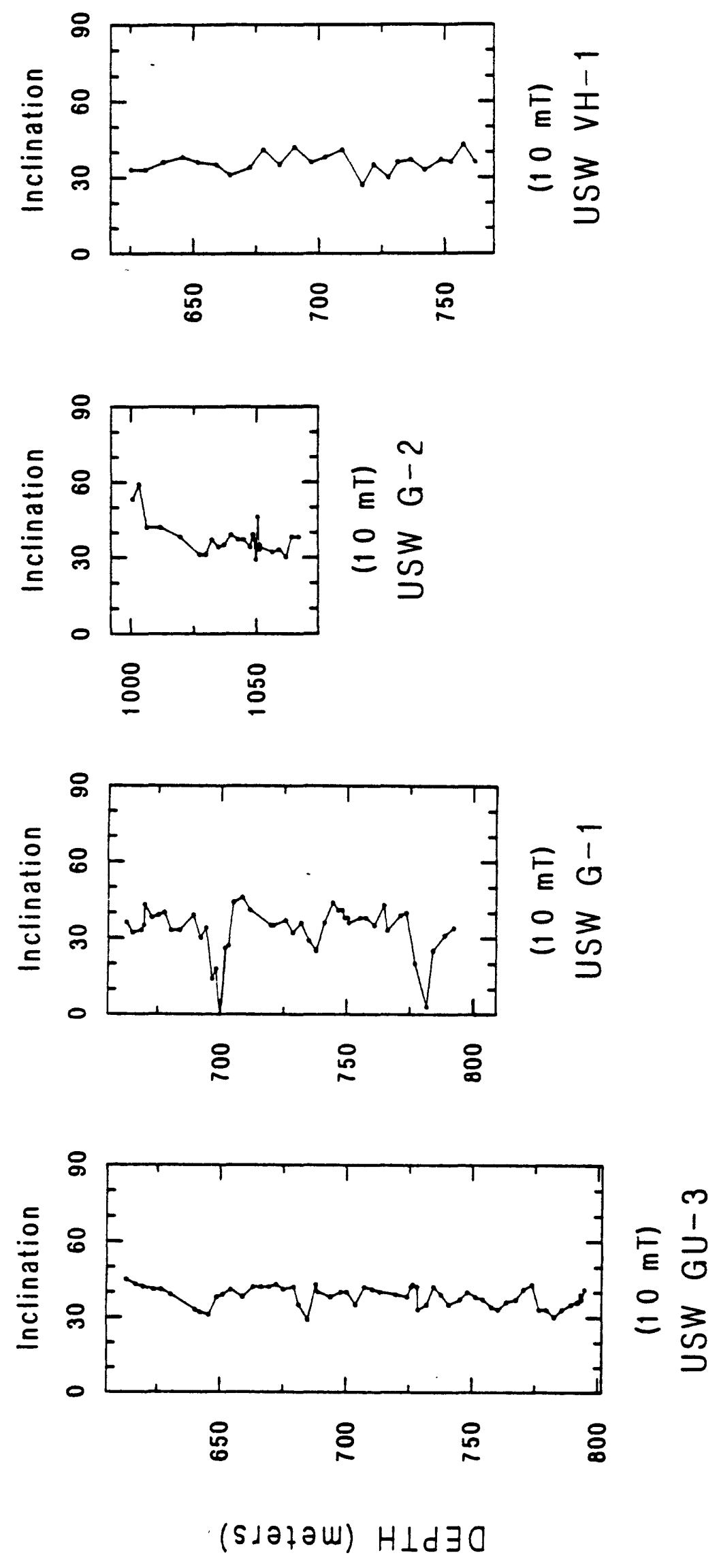

㫕

론

㟧

葛

先

它㖏

눙으

44

뭉

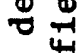

苞

"

건

岂

讨

至

용

岁罟

5

봉

$\frac{0}{\pi}$

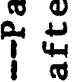

出

of 


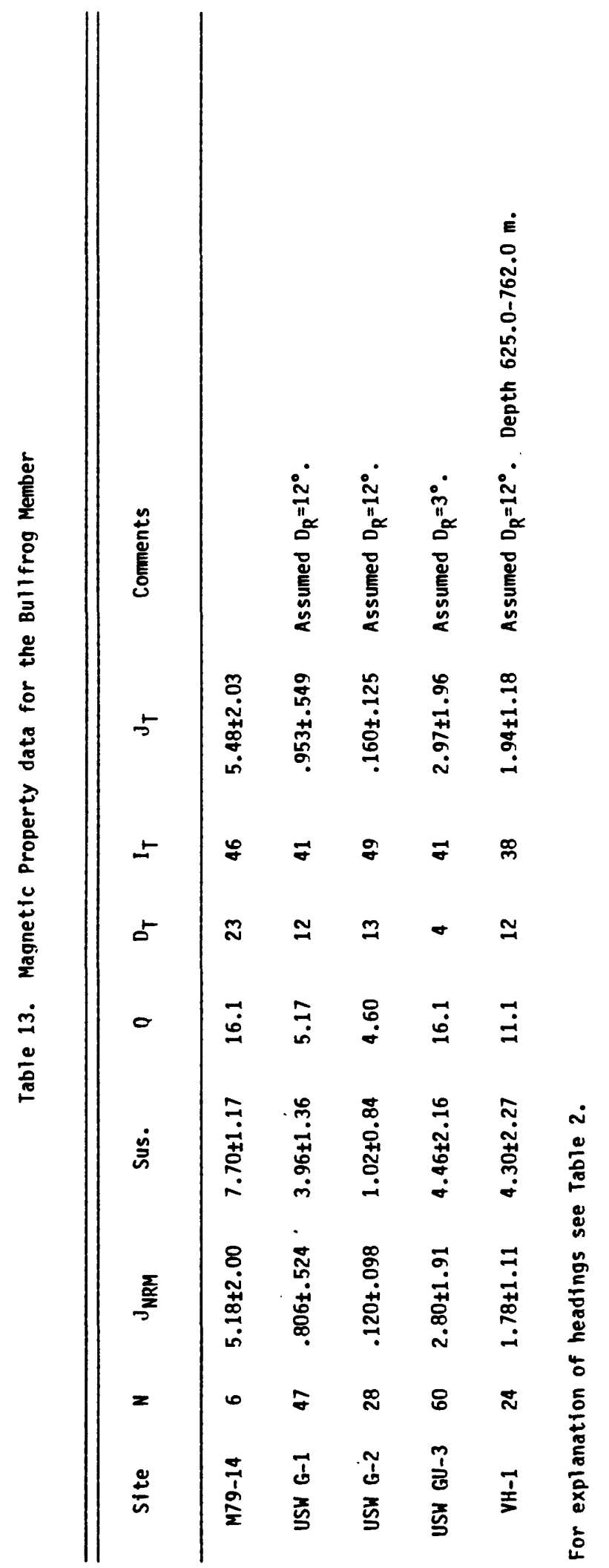



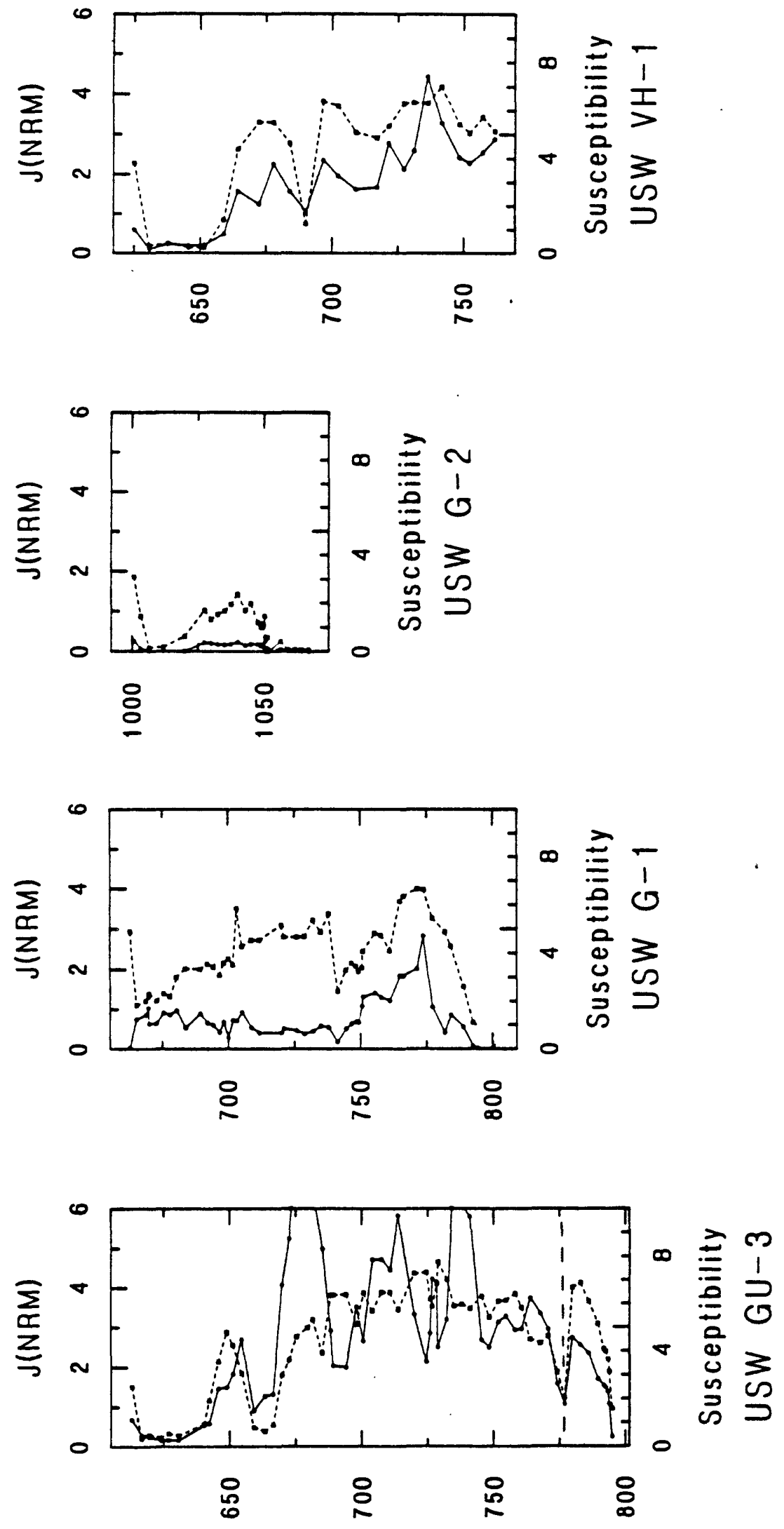

(s」ว子әس) $H \perp d \exists C$

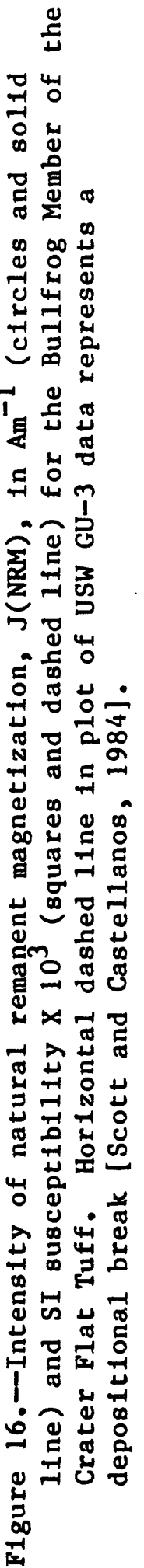


Tram Member: The Tram Member was sampled in drill holes USW G-1, G-2 and G-3. At Yucca Mountain the Tram can be divided into upper (lithic-poor) and lower (lithic-rich) zones. Both zones occur in holes USW G-1 and G-3, but only the lithic-rich zone occurs in USW G-2 [Spengler and others, 1981; Maldonado and Koether, 1983; Scott and Castellanos, 1984].

Oriented specimens obtained from USW G-1 and G-3 yield reversed directions with south-easterly declinations (Figure 14 and Table 14). Al though the data from USW G-1 give a smaller $\alpha_{95}$ and larger precision parameter than those from USW G-3, it is likely that the G-3 data is more representative since the number of samples and the stratigraphic interval sampled are much greater for this hole than for USW G-1.

Inclination data for the Tram Member from USW G-3 remain quite uniform from near the top of the unit to a depth of about $1080 \mathrm{~m}$ (Figure 17). No substantive change in inclination occurs across any of the thin bedded intervals which occur at depths of $860,911,934.1$, and $952.4 \mathrm{~m}$ [Scott and Castellanos, 1984] indicating that the entire unit was emplaced rapidly with respect to secular variation. Below this depth the inclination record becomes increasingly irregular. This zone is al so characterized by increasing al teration (to zeolites and clay) of the tuff with depth [Scott and Castellanos, 1984], suggesting that the greater variations in the inclination record is a result of the acquisition of secondary components of remanence during the alteration of the tuffs. The inclination record from USW G-1 is relatively uniform in the upper $20 \mathrm{~m}$, rather irregular for the next $50 \mathrm{~m}$, again relatively uniform for 100 to $125 \mathrm{~m}$, and then increasingly erratic in the lowermost $90 \mathrm{~m}$ of the unit (Figure 17). No reason is readily apparent for the irregular record between the depths of 825 and $875 \mathrm{~m}$. However, as in USW G-3, the irregular record from the lower portion of the Tram Member corresponds to a zone of increased al teration [Spengler and others, 1981]. The Tram Member encountered in USW G-2 is relatively thin, lithic-rich and argillized [Maldonado and Koether, 1983]. It yields an extremely erratic inclination record throughout its thickness.

The upper lithic-poor portion of the Tram Member is characterized by high remanent intensities (Table 15) which increase from values of a few tenths to one $\mathrm{Am}^{-1}$ near the top of the unit to maxima in the interior of the unit of nearly 6 and $15 \mathrm{Am}^{-1}$ at USW G-1 and G-3, respectively (Figure 18). As the magnetization decreases bel ow these maxima the degree of welding also tends to decrease while the lithic content and the degree of alteration increase [Spenger and others, 1981; Scott and Castellanos, 1984]. Within this upper zone, changes in susceptibility correlate highly with changes in remanent intensity.

The lithic-rich lower zone is characterized by much lower remanent intensities than the upper zone (Table 15). Maldonado and Koether [1983] divide this portion of the Tram Member in drill hole USW G-2 into two parts, a unit consisting of more than $50 \%$ lithics above a depth of $1135 \mathrm{~m}$ and one comprising less than $50 \%$ lithics below this depth. As can be seen in Figure 18 both susceptibility and remanent intensity curves change abruptly at this depth. Although magnetization remains low throughout the lower lithic-rich al tered portion of the Tram Member in USW G-1 and G-3, susceptibilities between 995-1060 $\mathrm{m}$ in USW G-1 and in the lowermost $75 \mathrm{~m}$ of the unit in USW G-3 are of about the same magnitude as those in the lithic-poor upper portion. 


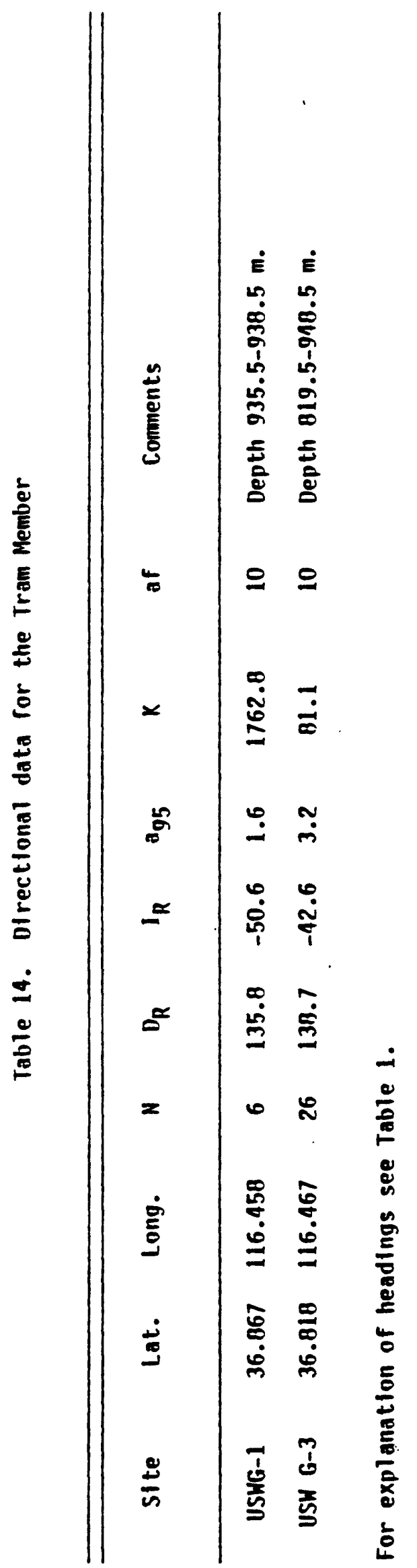




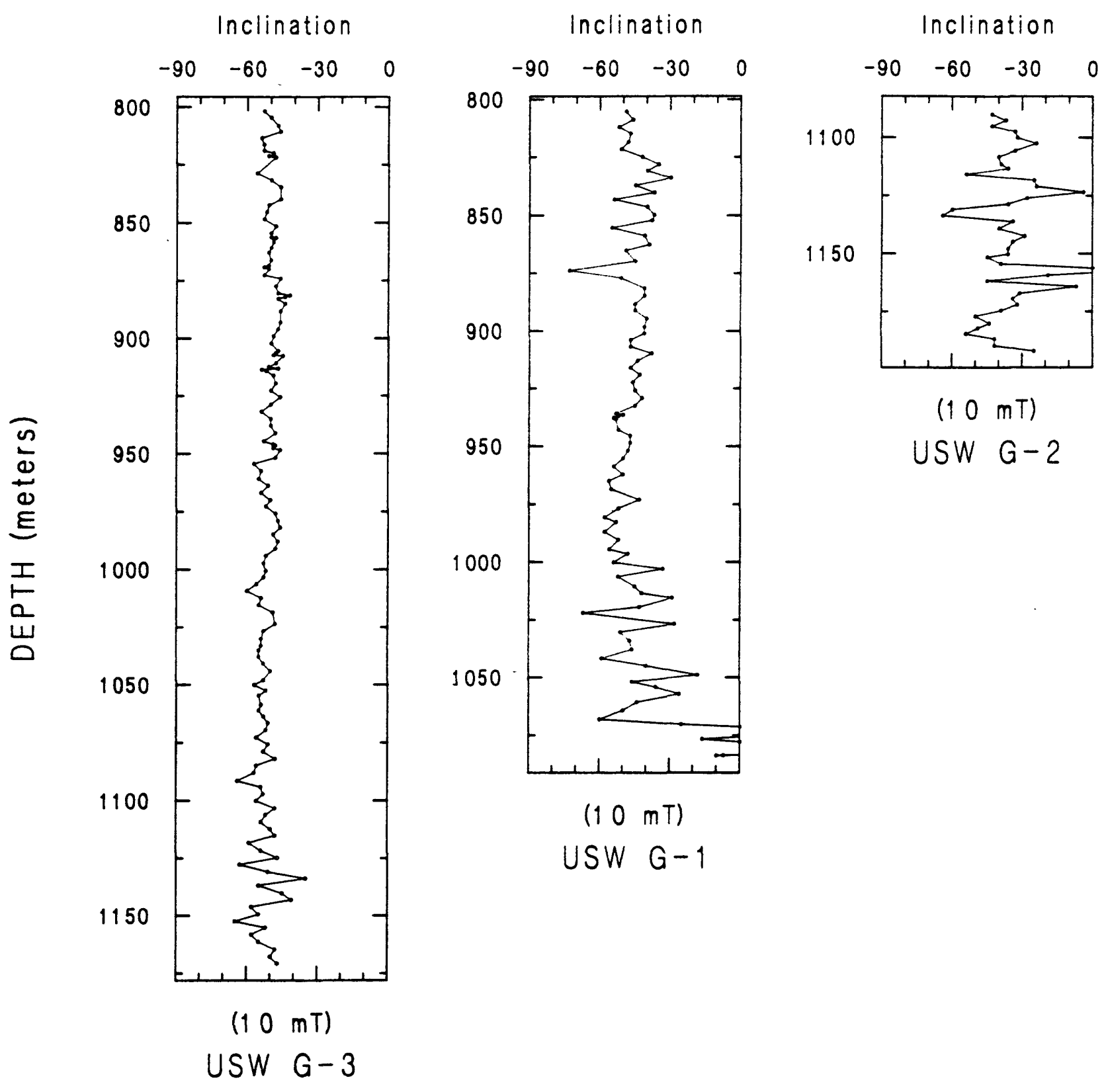

Figure 17.-Paleomagnetic inclinations versus depth for the Tram Member of the Crater Flat Tuff after a demagnetization at a peak field of $10 \mathrm{mT}$. 


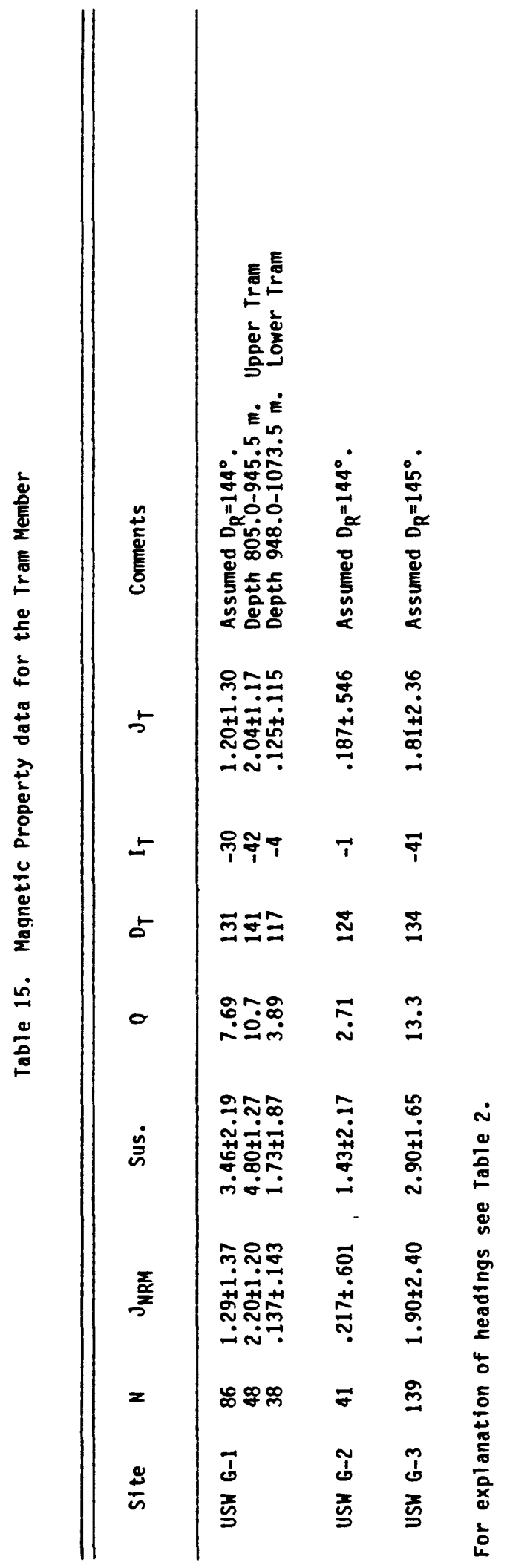



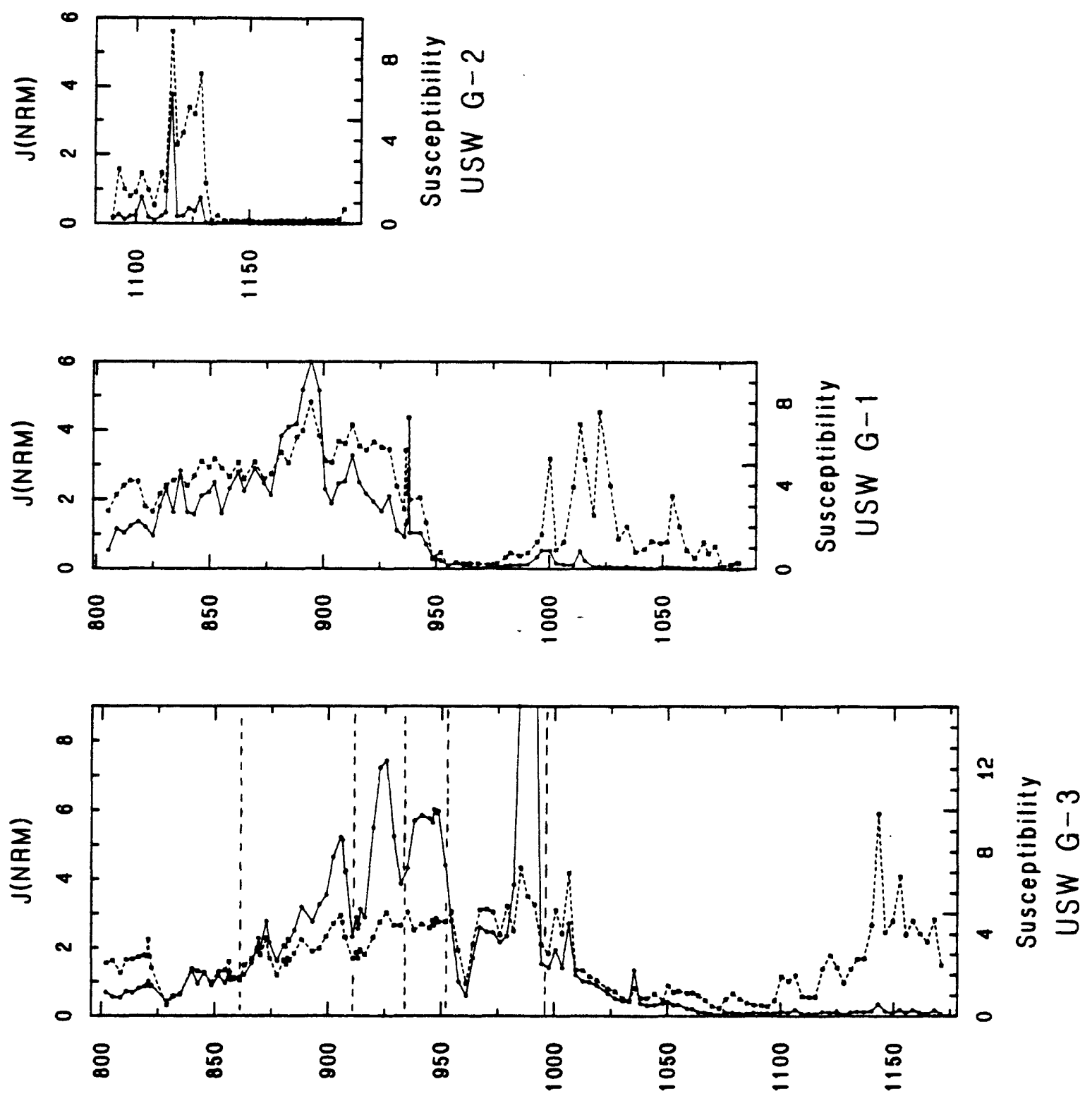

(s」ә子วU) $H \perp d \exists O$

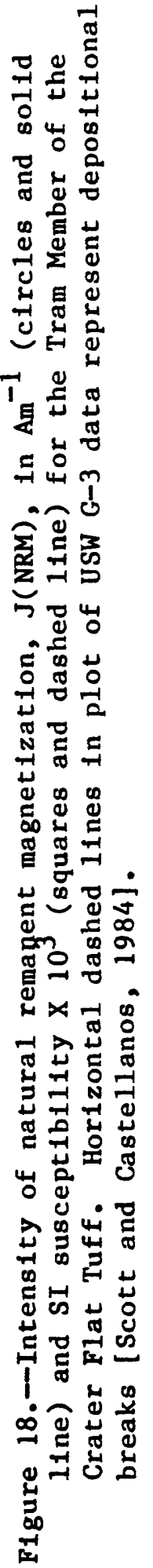


Comparison of the magnetic properties to the lithologic description of the Tram Member from dril1 hole USW G-3 [Scott and Castellanos, 1984] reveals a good correspondence between geologically recognizable breaks in deposition and changes in magnetic properties. Scott and Castellanos [1984] recognized at least five depositional breaks. The upper four occur at depths of about $860,911,934$ and $952.4 \mathrm{~m}$ and are marked by the presence of thin bedded tuffs. The fifth occurs at about $994 \mathrm{~m}$ at the base of an ash flow and was recognized by a minimum in the degree of welding. One of the four largest remanent intensity maxima occurs between each pair of adjacent depositional breaks (Figure 18) and the breaks fall at or near intensity and susceptibility minima. The largest of these maxima occurs just below a vitrophyre

(982.1-983.7 m) [Scott and Castellanos, 1984]. A similar relationship between magnetic properties and a depositional break was noted for the Bullfrog Member. These observations and those of Hatherton [1954a; 1954b] indicate that at least some of the variation in magnetization may be related to the depositional history of the tuff. The mechanisms responsible for these variations are unknown but may include: (1) variation of the composition (i.e. magnetite content) of the erupted magma with time; (2) post-emplacement growth of fine-grained magnetic phases which occurs to a greater extent in one portion of the flow than another (perhaps more time for growth in the more slowly cooling interior than at the flow margins); and (3) greater oxidation of fine-grained magnetite at the top and bottom of the flows either at high temperature (during cooling) or at low temperture. Regardless of the mechanism, the correlation between remanent intensity variations and depositional breaks suggests that these variations could provide a useful tool for mapping the internal stratigraphy of thick compound cooling units.

\section{Other Units}

Lava Flows and Flow Breccias between Tram Member and Tuff of Lithic Ridge: The dacite and rhyodacite lava flows and flow breccias underlying the Tram Member in the northern part of Yucca Mountain [Spengler and others, 1981; Maldonado and Koether, 1983] were sampled throughout their vertical extent in drill holes USW G-1, G-2, and at four depth intervals in USW H-6. These units are not present in USW G-3.

The inclination data from USW G-1 and G-2 vary to such a degree that even a magnetic polarity (normal or reversed) for these rocks cannot be determined from these data (Figure 19). This erratic record may be due to alteration of the rocks, or it may indicate that the individual blocks comprising the breccia had cooled sufficiently to acquire their remanence prior to emplacement. In contrast, the dacite lava flows from USW H-6 yield exclusively downward directed magnetic vectors with inclinations ranging between $25^{\circ}$ and $40^{\circ}$ (Figure 19). Therefore, the unit is considered to be of normal polarity $\left(D_{R}=0^{\circ}\right.$, was assigned for the calculation of the total magnetization, see Table 16).

In samples from USW G-1 and G-2 remanent intensity averages only a few tenths of an $\mathrm{Am}^{-1}$; however, susceptibility values are quite high (Figure 20 and Table 16). Intensities from two levels in USW H-6 are of similar magnitude to those in USW G-1 and G-2, and at two levels are much greater. Oniy samples of vitrophyre from a depth of $1100 \mathrm{~m}$ in USW H-6 have susceptibilities of the level observed in the other holes. 


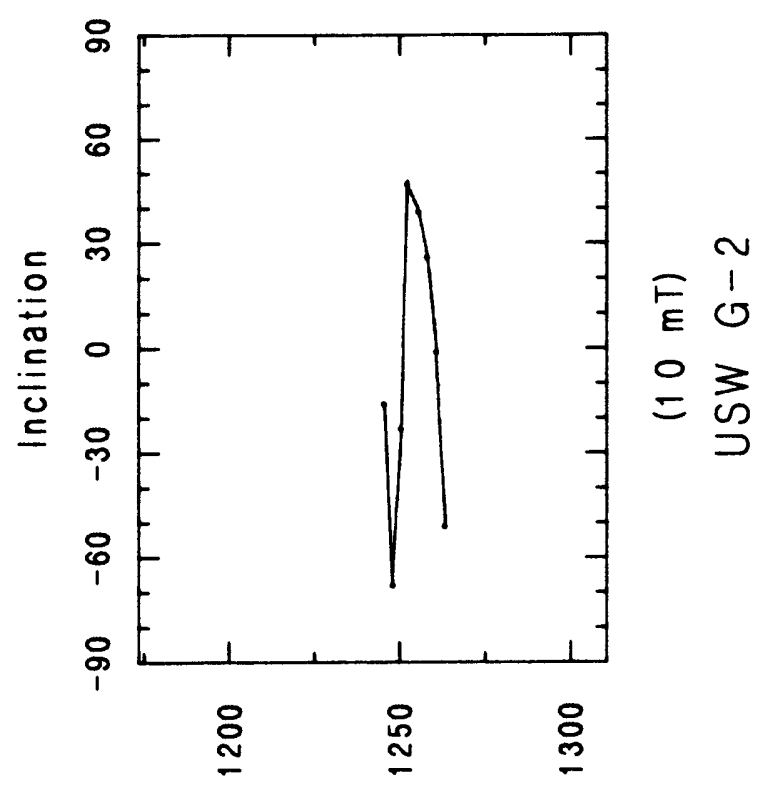

告
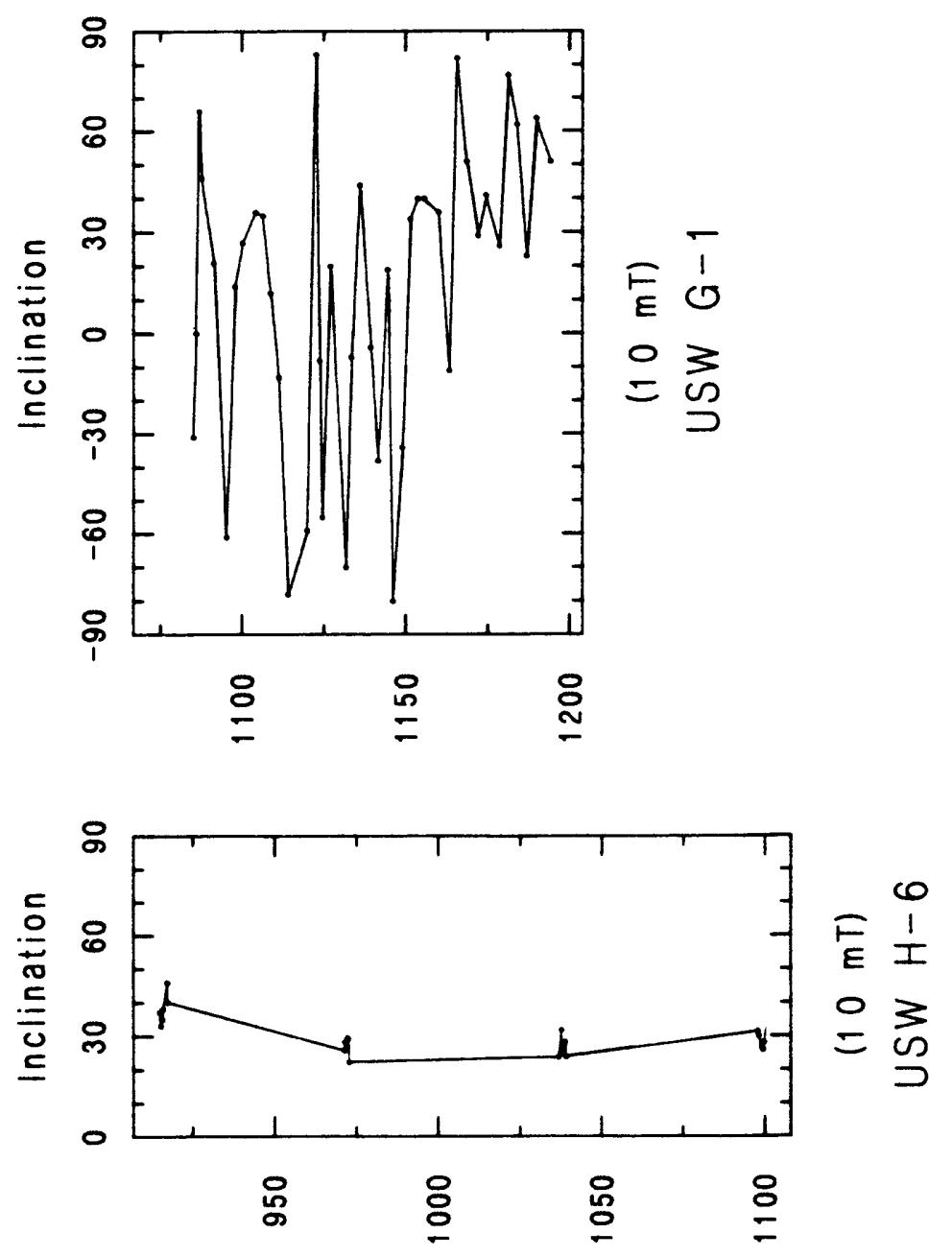

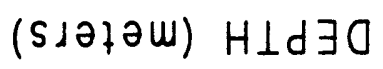

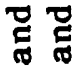

出

至

$\underset{\sigma}{0}$

番

岀岕菑

둥으

递㟧

옥둥

o

出

है

类嵒

용

远

다

تิ

돈

บ ธี

I

嵌

.

实

๑ 엉

१ٓ

인

व

㟧 


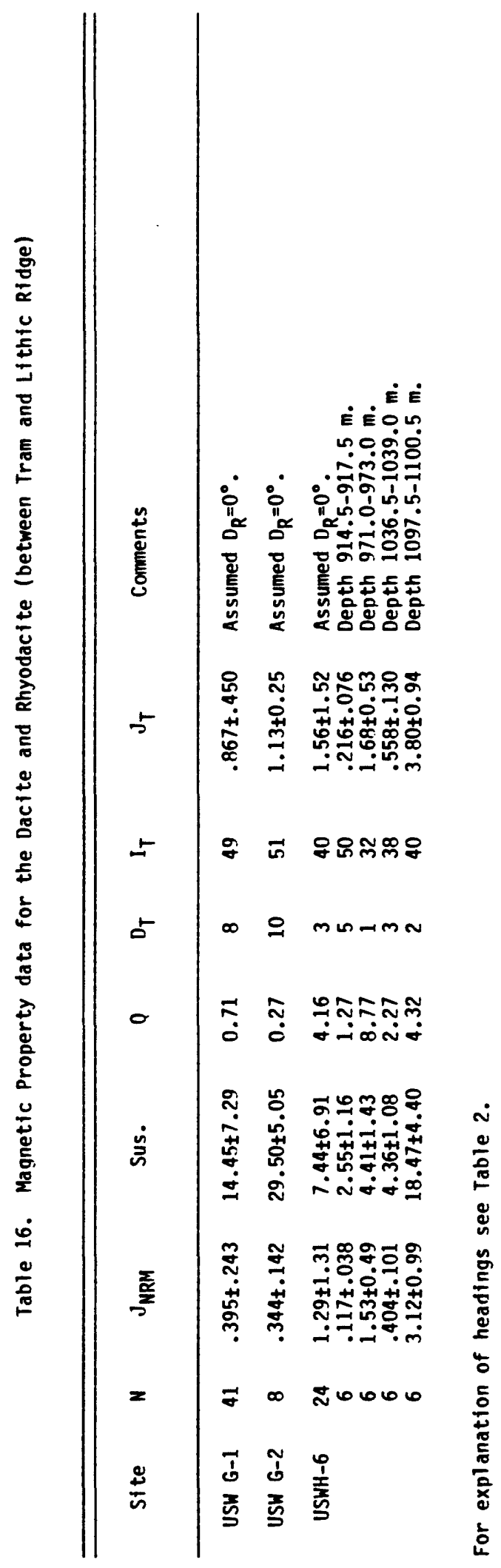



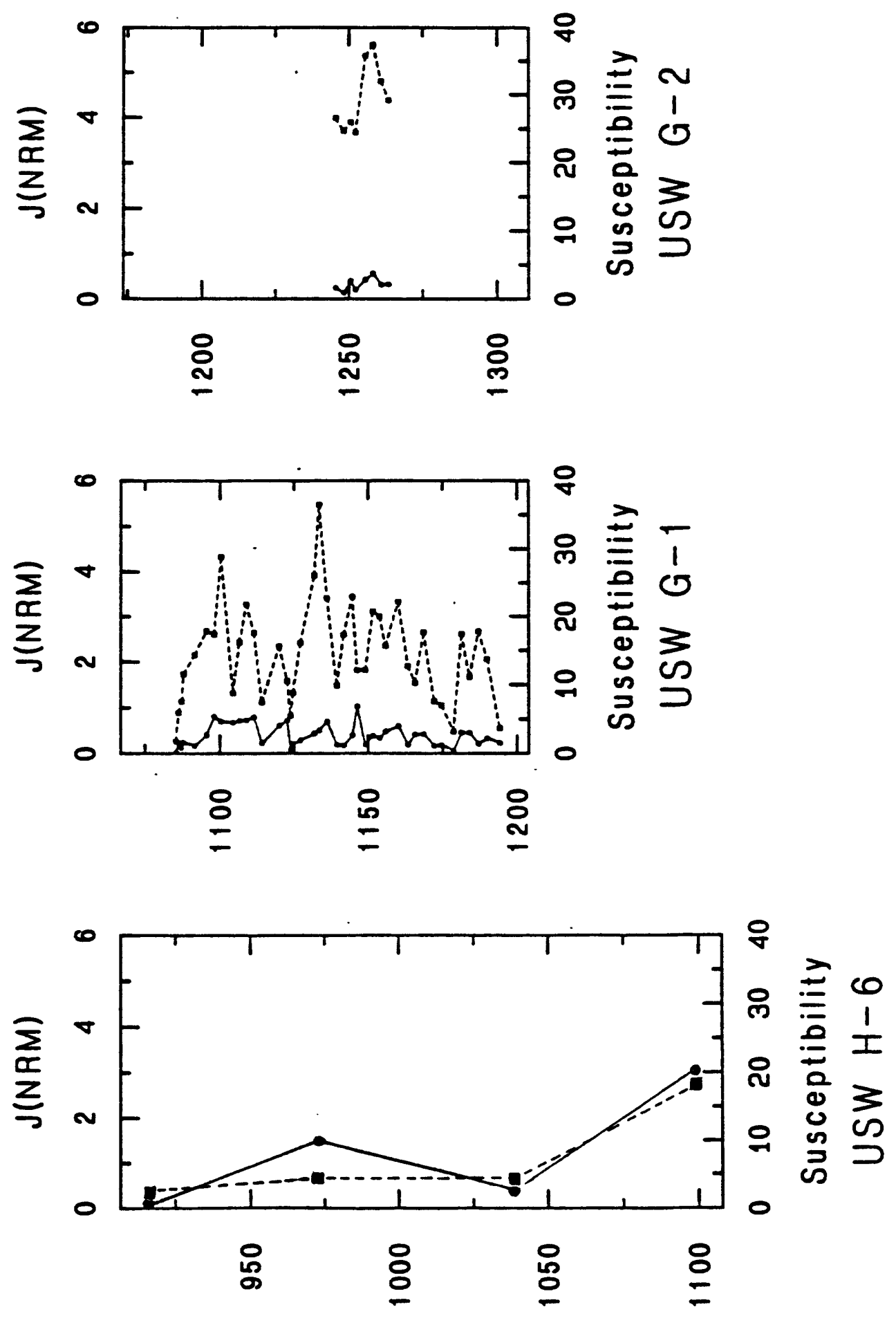

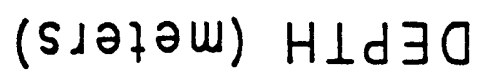


The rock obtained from USW H-6 appears to be much less altered than that from USW G-1 and G-2. In addition, values of $Q$ computed for the various levels sampled in USW $H-6$ are substantially greater than those obtained from USW G-1 and G-2. These observations suggest that alteration has destroyed much of the fine-grained magnetite at the USW G-1 and G-2 localities, and that if these rocks were unaltered they would possess much higher remanent intensities.

Lithic Ridge Tuff: The Lithic Ridge Tuff was sampled throughout its thickness in drill holes USW G-1, G-2, and G-3. Oriented specimens were obtained from all three of these holes as well as from outcrop at the type locality at Lithic Ridge (site JR81-10) [Carr and others, 1984]. Although the inclination data form the entire unit as a whole are extremely erratic (Figure 21), af demagnetization of the oriented specimens yielded mean directions of remanent magnetization from each of the three drill holes that are to the southwest and nearly horizontal (Table 17). The mean directions of remanent magnetism of the outcrop samples after af demagnetization at 5, 10 and $20 \mathrm{mT}$ differ significantly from those obtained from the drill holes (Figure 22 and Table 17). However, the average direction of vectors removed during demagnetization between 5 and $20 \mathrm{mT}$ is in good agreement with the directions determined from the three holes (Figure 22f). The outcrop samples apparently possess both a soft remanence (probably a viscous remanence), which is largely removed by af demagnetization in a peak field of $5 \mathrm{mT}$ (Figure 22b), and a rather hard, secondary magnetization (probably a chemical remanent magnetization) which remains after demagnetization at $20 \mathrm{mT}$ (Figure 22a). These components tend to obscure the initial remanence of the unit. Similar components may be present in the drill hole samples and account for the irregular inclination records.

It should be noted that the directions presented in Table 17 and Figure 22 have not been corrected for tectonic rotation. This implies that the Lithic Ridge Tuff at Yucca Mountain has a similar attitude to that at the type locality. Nevertheless, the good agreement of directions from this unit at Yucca Mountain and at the type locality strongly supports the equivalence of these rocks.

Variations in remanent intensity of the Lithic Ridge Tuff with depth display a high degree of correlation with susceptibility variations fFigure 23). Average intensities from the drill holes are less than $0.2 \mathrm{Am}^{-1}$ and from outcrop only slightly higher (Table 18). Both susceptibility and intensity generally decrease with depth. This may be due to increasing alteration with depth, although such a change is not evident from petrographic descriptions of the core [Spengler and others, 1981; Maldonado and Koether, 1983; and Scott and Castellanos, 1984].

01der Tuffs of USW G-1, and Lava Flows and Flow Breccias of USW G-2; Spengler and others [1981] divide the older tuffs encountered in drill hole USW G-1 into three units, $A, B$, and $C$. Inclination data from these tuffs are for the most part erratic. Because of the highly altered nature of these rocks it is impossible to confidently interpret magnetic polarities for these ash-flow tuffs. Nevertheless, two zones from which oriented samples were obtained yield reasonably consistent directions. One, from unit $C$ at the bottom of drill hole USW G-1, is normal; the other, from rocks at the bottom of USW G-3 which correlate with unit A [Scott and Castellanos, 1984], is reversed (Table 19). 


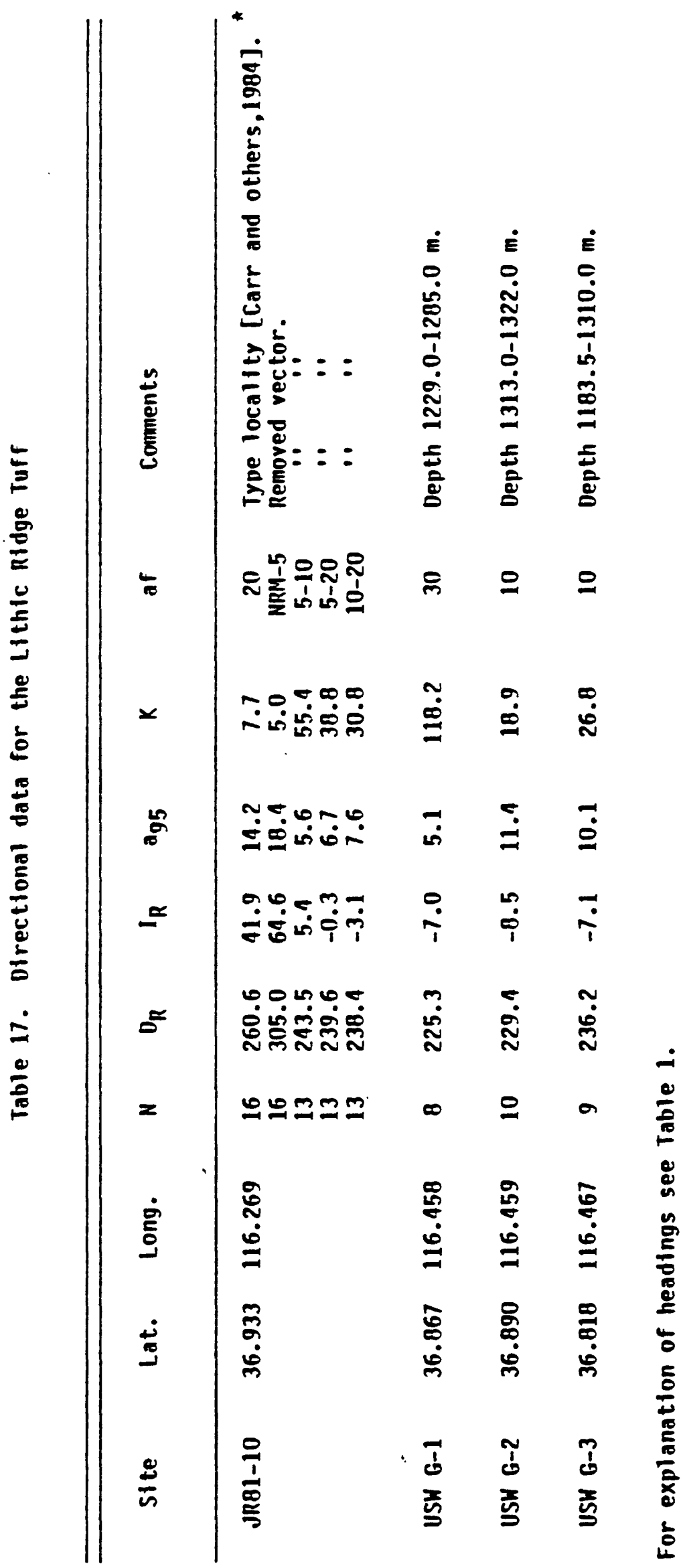



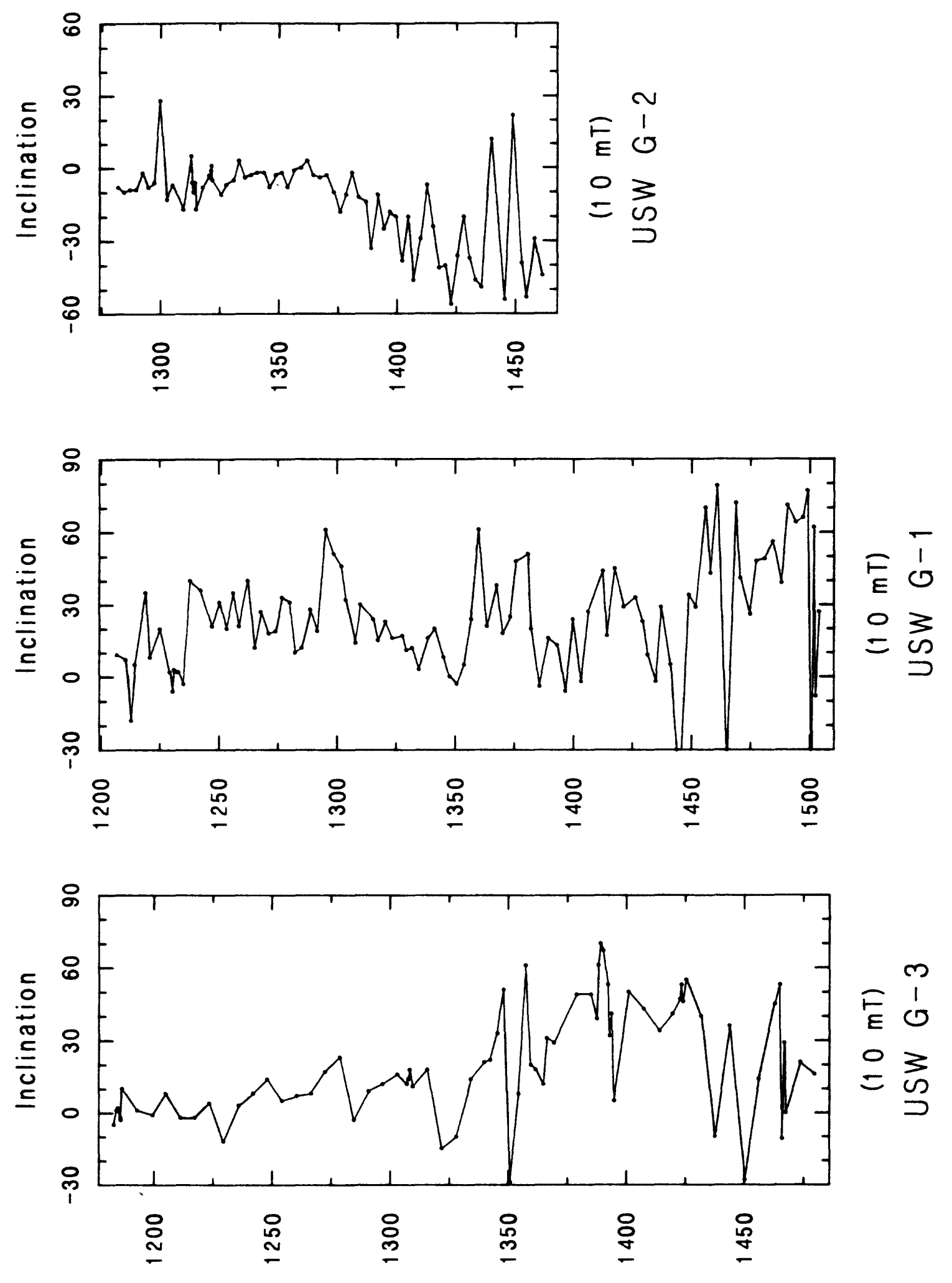

(s」วғวس) $H \perp d \exists O$ 


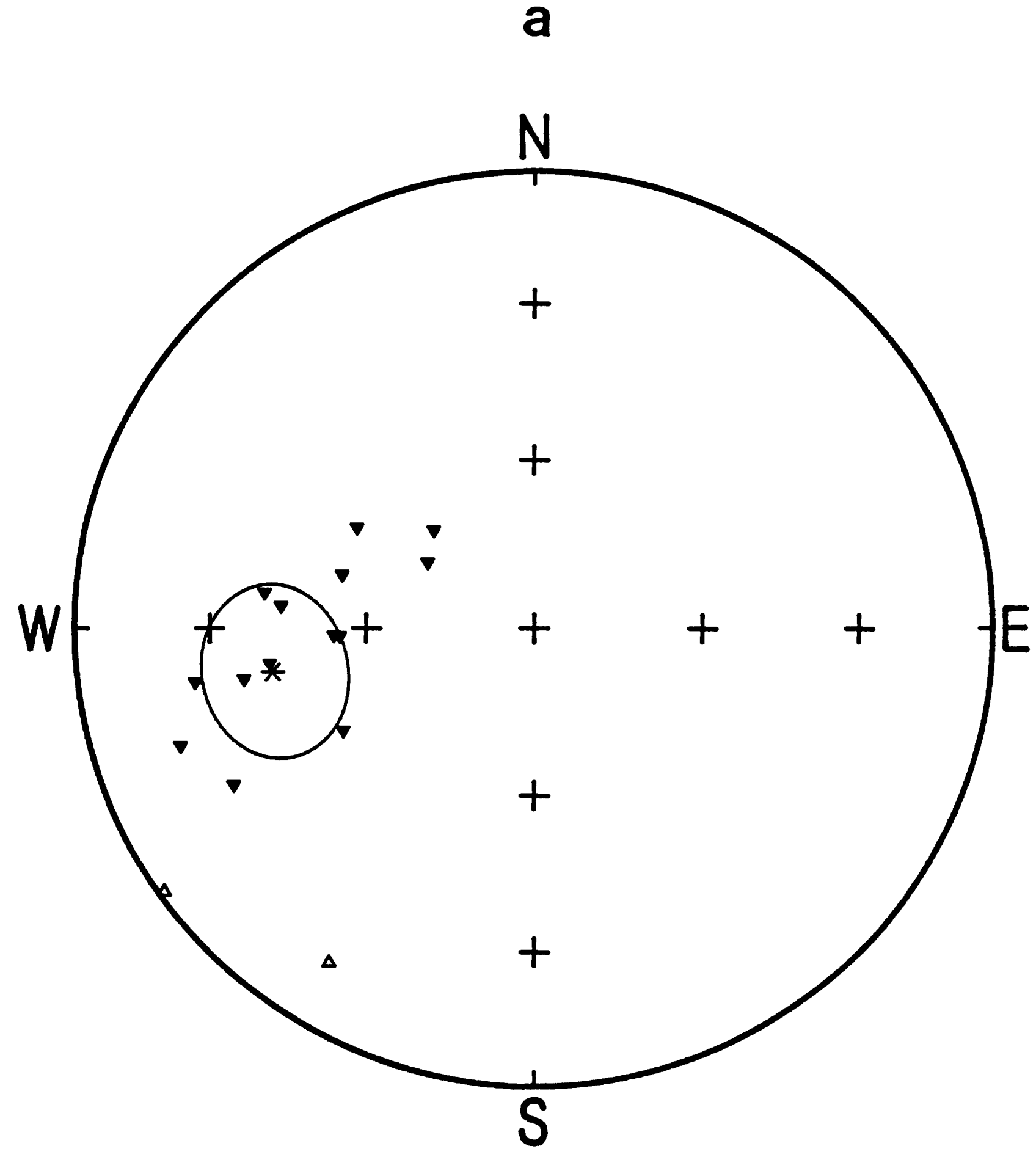

Figure 22.-Equal area projections of paleomagnetic directions from the Lithic Ridge Tuff: a through e are results from site JR81-10 at Lithic Ridge [Carr and others, 1984] (see Table 17); * is mean direction, solid triangles are sample directions on lower hemisphere, open triangles are sample directions on upper hemisphere, circles are sample directions not included in calculation of the mean (all are on lower hemisphere) a) residual vectors after af demagnetization at $20 \mathrm{mT}$; b) vectors removed between NRM and $5 \mathrm{mT}$; c) vectors removed between 5 and $10 \mathrm{mr}$; d) vectors removed between 10 and $20 \mathrm{mT}$; e) vectors removed between 5 and $20 \mathrm{mr}$; f) mean directions of remanent magnetization and associated cone of $95 \%$ confidence from drill holes USW G-1, G-2, G-3 after af demagnetization at peak fields of 30,10 , and $10 \mathrm{mT}$, respectively, and of vectors removed between 5 and $20 \mathrm{mT}$ for site JR81-10. 
b

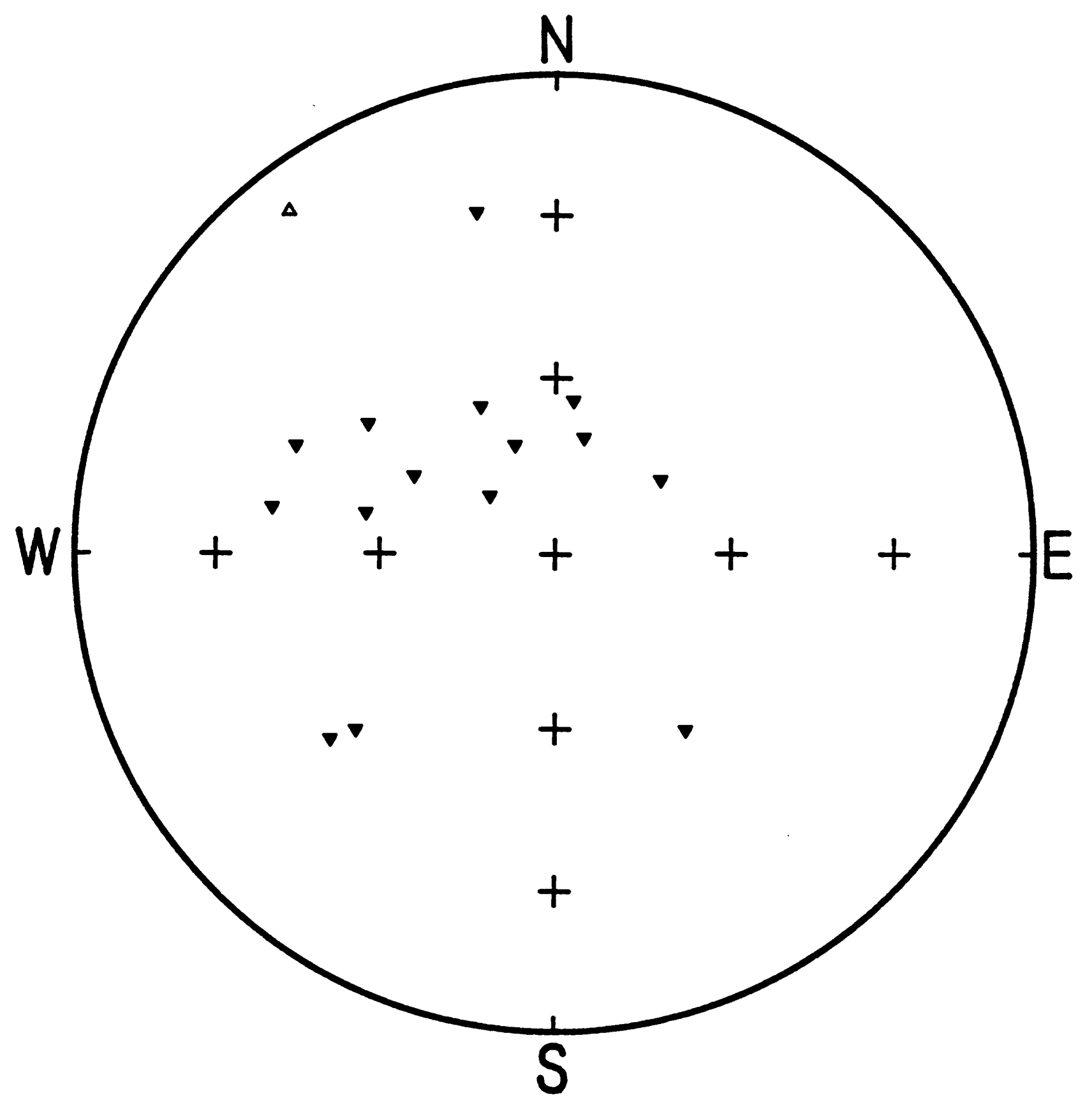

Figure 22.-continued 


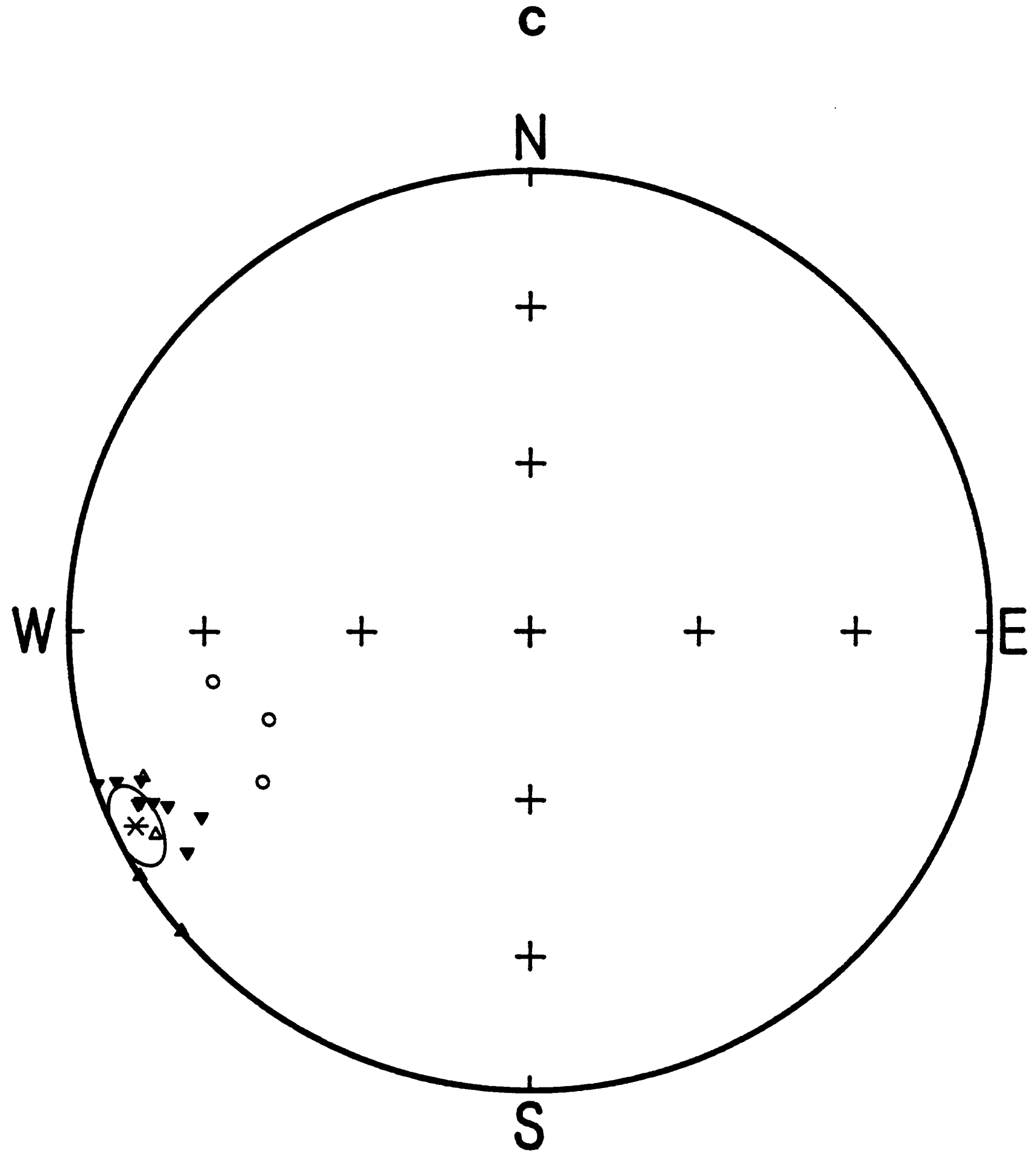

Figure 22.-continued 


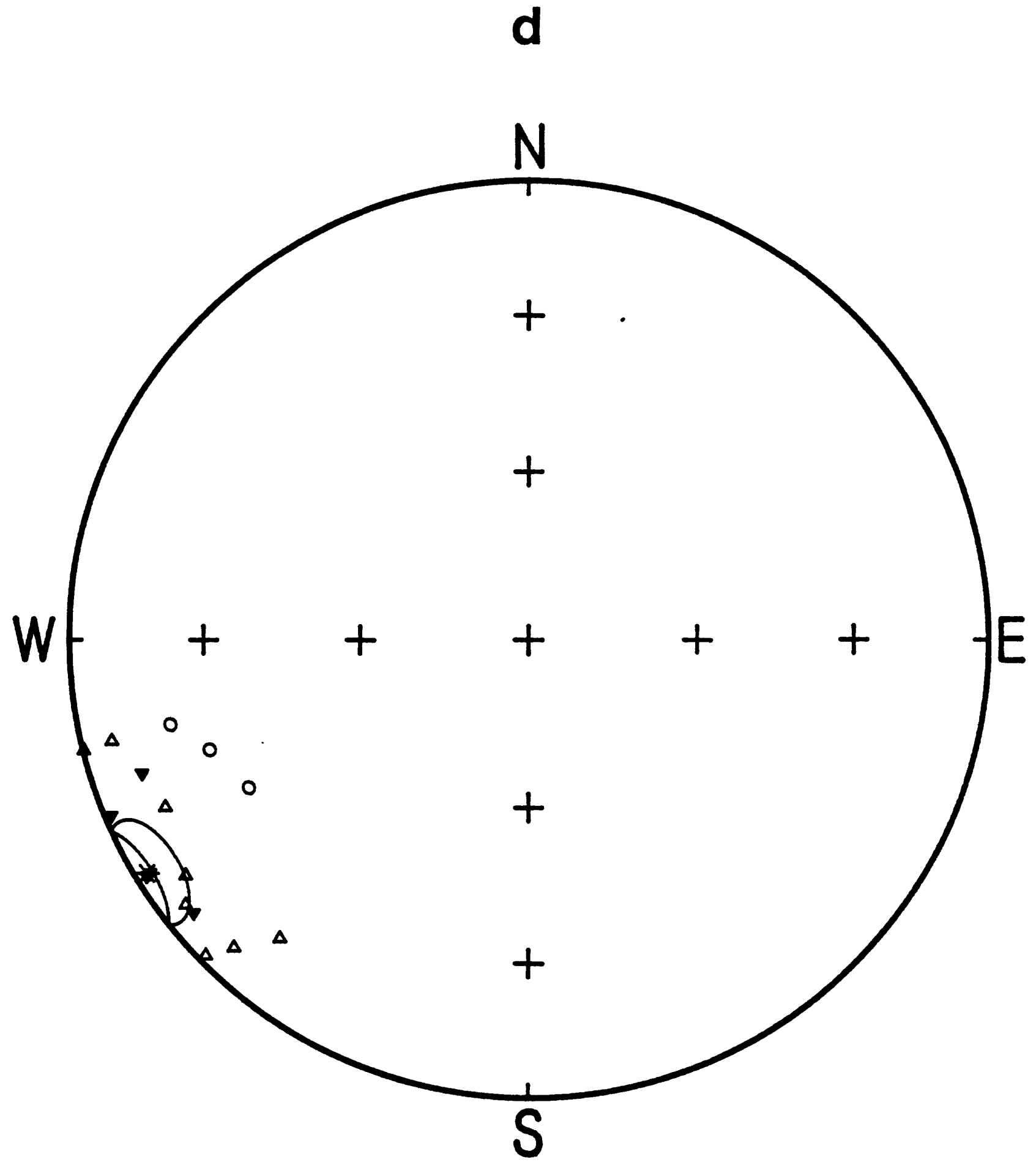

Figure 22.-continued 
e

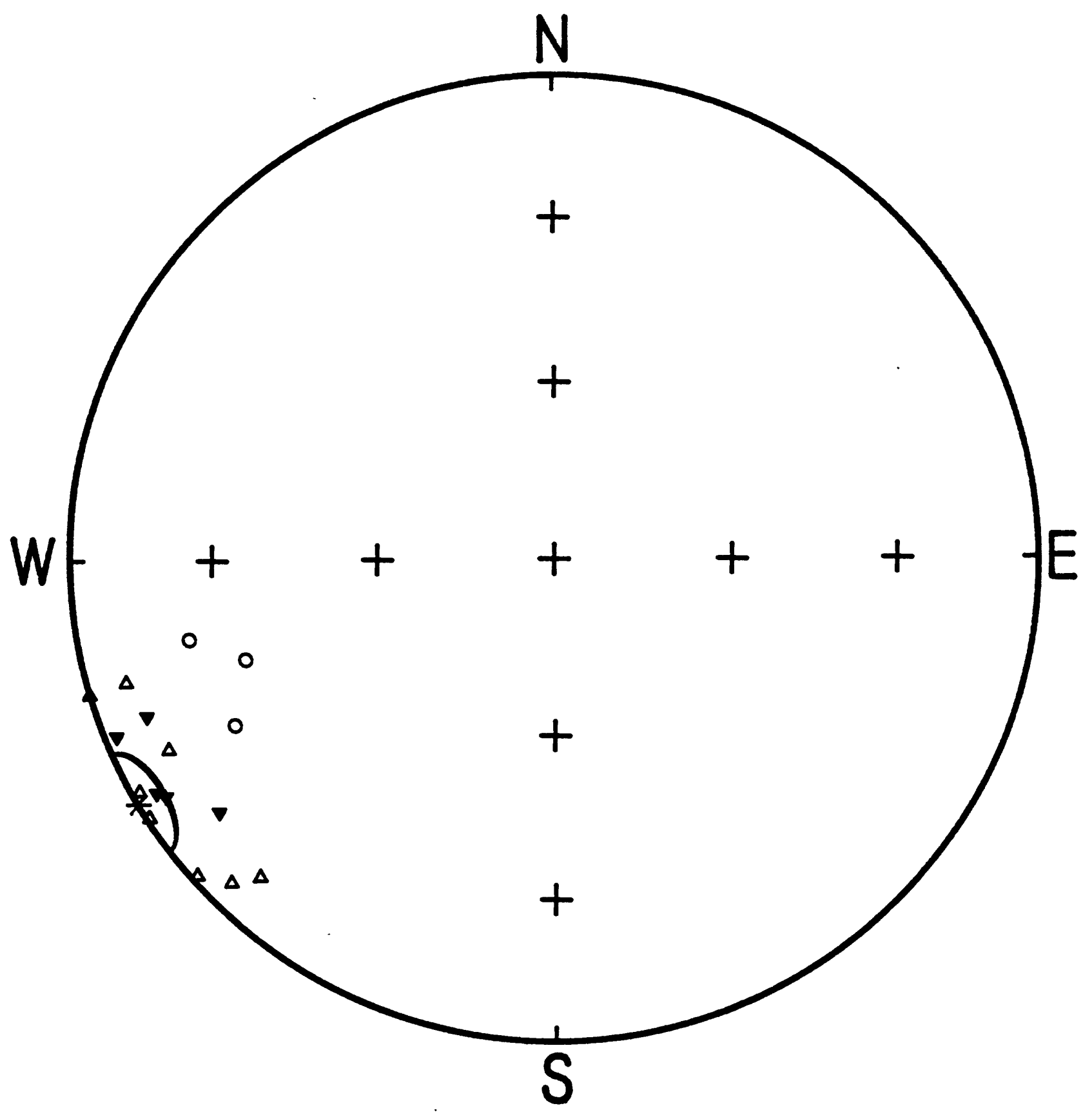

Figure 22.-continued 
f

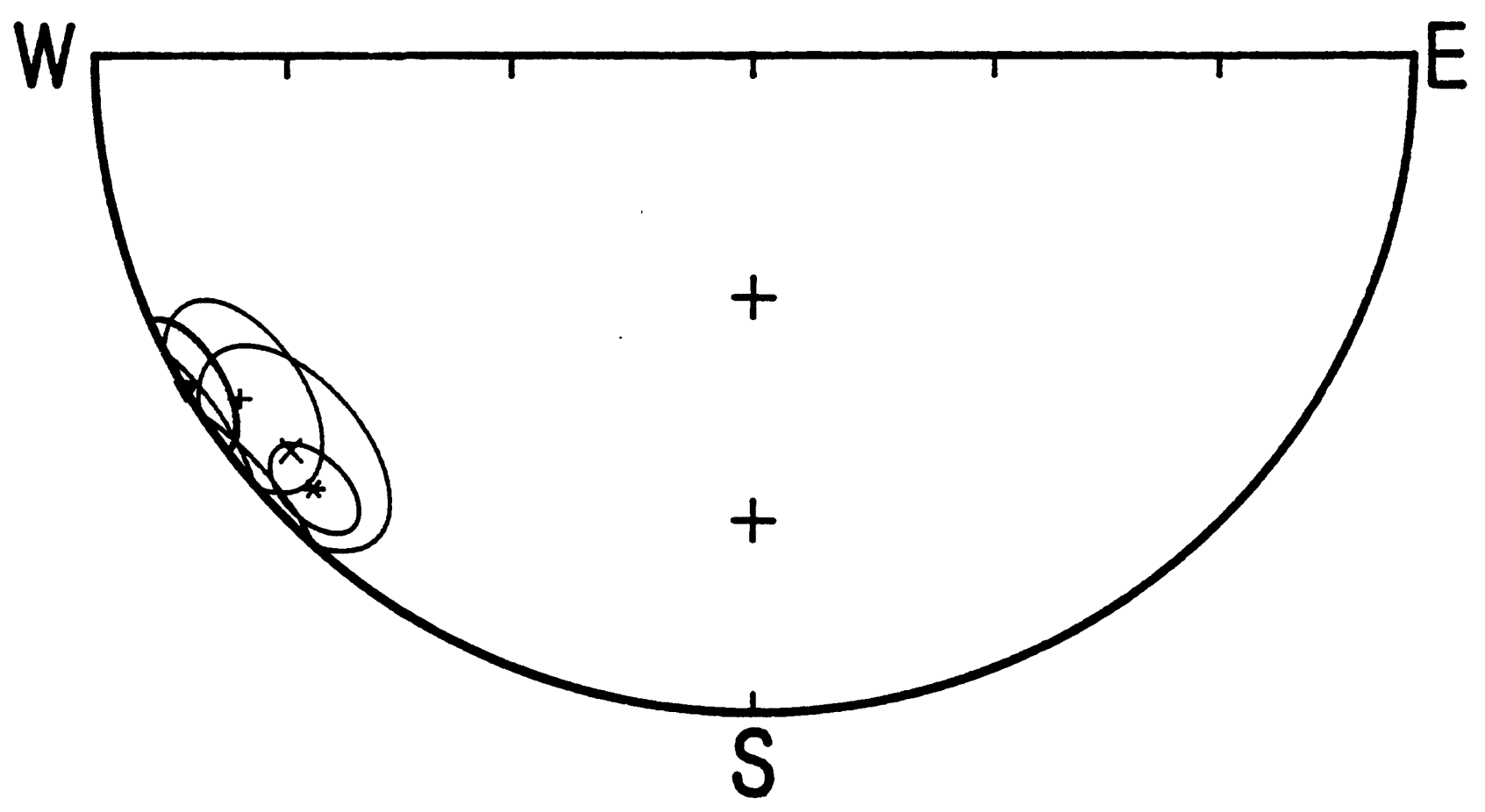

Figure 22.-continued 


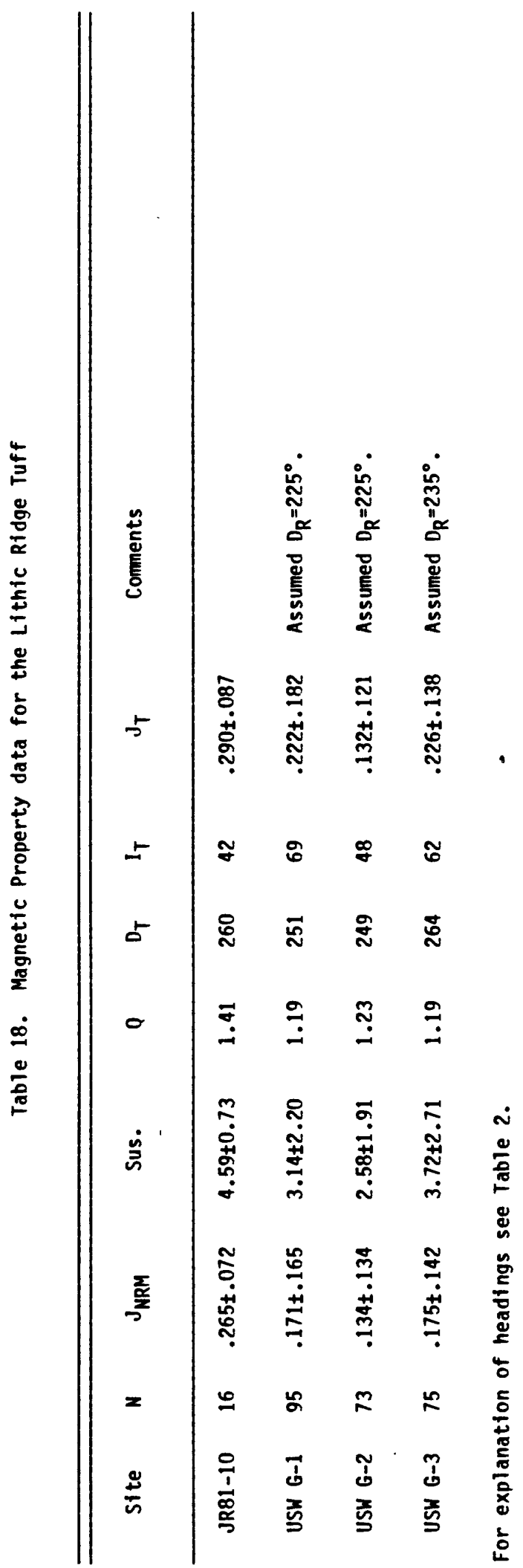




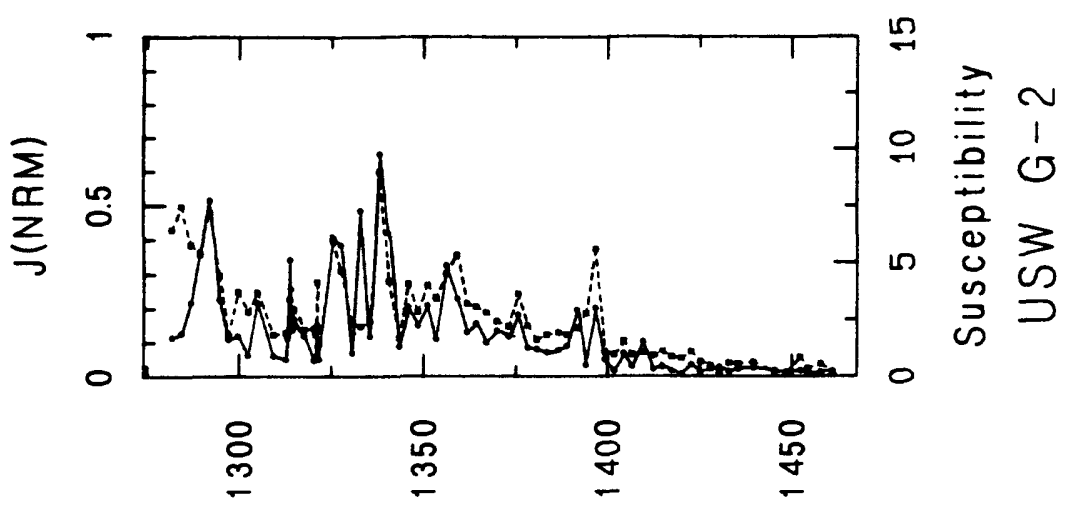

节茾

ซึ

is $\vec{x}$

。

눈

已़

广是站

둥
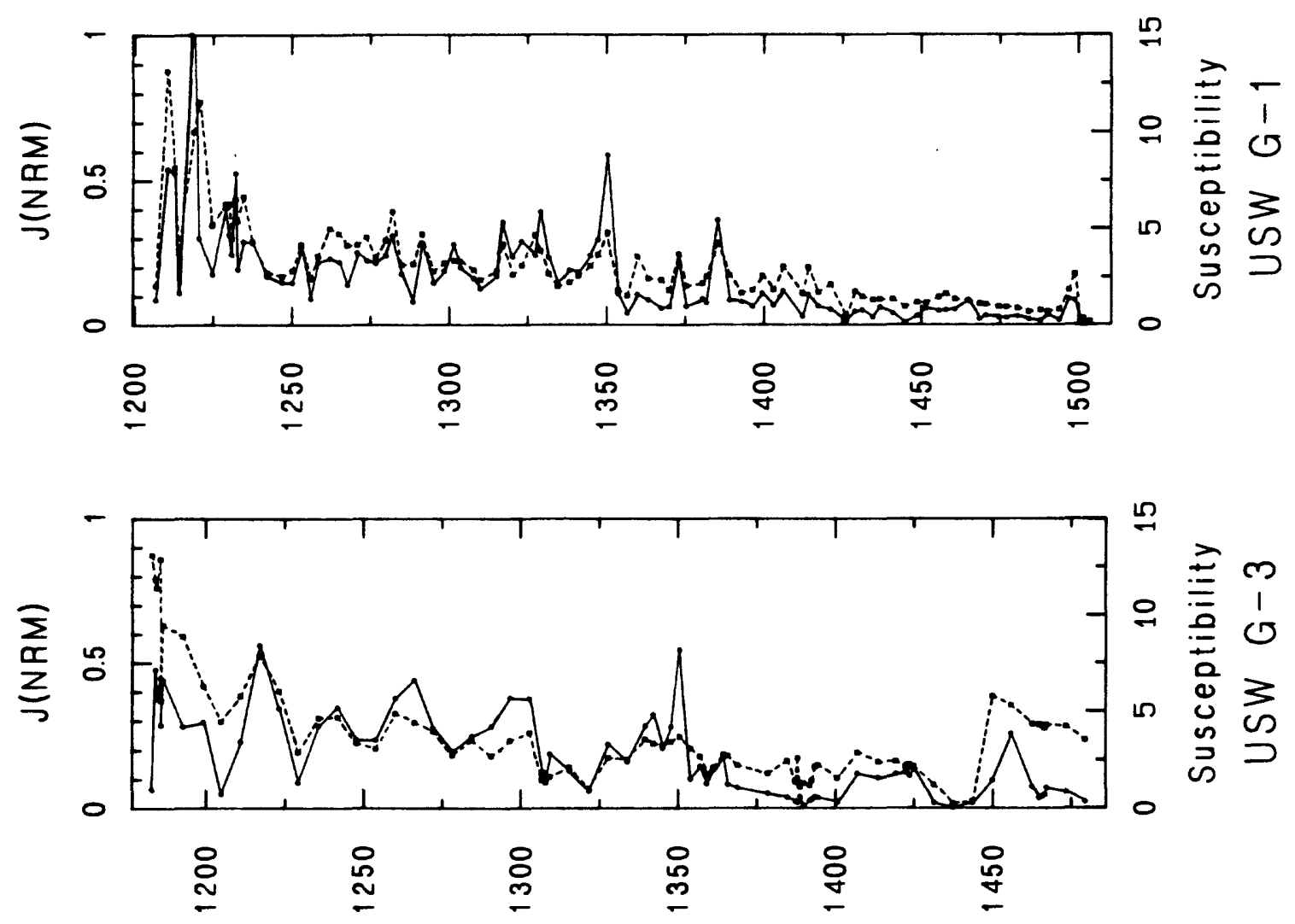

(s」ว子วس) $H \perp d \exists O$ 
The thick sequence of older ash flows penetrated in the bottom of USW G-1 is not present in USW G-2. Only a single thin ash-flow tuff which apparently correlates with a thin tuff at the top of unit $C$ represents this part of the section [Maldonado and Koether, 1983]. A sequence of lava flows and flow breccias occurs below this tuff at the locality of USW G-2. With increasing depth the composition of these flows changes from rhyolite, to quartz latite, and finally to dacite. These rocks are highly altered. All but two of 33 samples of the rhyolite have negative remanent inclinations, whereas all 40 samples of the quartz latite and 21 samples of the dacite have positive inclinations. Therefore, the rhyolite appears to be of reversed polarity while the older more mafic lavas are of normal polarity.

The average magnetic properties for units penetrated in drill holes USW G-1, G-2 and G-3 below the Lithic Ridge Tuff are summarized in Table 20. Total magnetizations for these rocks are plotted in Figure 24.

The uppermost part of unit $A$ in USW G-1 and all of the unit sampled from USW G-3 are characterized by extremely low remanent intensities ( $<<0.1 \mathrm{Am}^{-1}$ ) and susceptibilities ( $\left.<2 \times 10^{-3} \mathrm{SI}\right)$. Both intensity and susceptibility values then rise so that $\mathrm{J}_{t}$ averages about $0.45 \mathrm{Am}^{-1}$ in the lower part of unit $A$ jn USW G-1 (Figure 24). Total magnetization of unit $B$ averages about $0.3 \mathrm{Am}^{-1}$ near the top of the unit, falls to extremely low values near the middle, and then rises sharply near the base of the unit. Unit C from USW G-1 is on average more magnetic than units $A$ and $B$, although its total magnetization curve varies erratically.

The composition of the lavas and flow breccias which occur beneath the Lithic Ridge Tuff in USW G-2 (and presumably stratigraphically below Unit $C$ of USW G-1) progress from rhyolite, to quartz latite, to dacite with depth [Maldonado and Koether, 1983]. Although these rocks are highly altered, they become more magnetic with depth and as their compositions become more mafic.

\section{DISCUSSION AND SUMMARY}

The interpretation of these data bear on stratigraphy, structure, and potential sources of magnetic anomalies in the vicinity of the Nevada Test Site. The data also raise several questions about the magnetism of welded tuffs.

Based upon the paleomagnetic directional data, declinations and inclinations from oriented specimens and inclination data from unoriented samples, the units can be assigned the polarities given in Table 21 . Due to various uncertainties, such as the directional variations demonstrated in the Topopah Spring Member of the Paintbrush Tuff and orientation errors of unknown magnitude in obtaining oriented cores from drill holes, and due to the fact that nearly all the data come from the Yucca Mountain block, no attempt has been made to define a precise direction of remanence for any of the units.

The polarity of the units is useful as a stratigraphic aid. For instance the petrographically similar Topopah Spring and Tiva Canyon Members of the Paintbrush Tuff are easily distinguished by their opposite polarities. In addition, the Lithic Ridge Tuff possesses very unusual (southwesterly and nearly horizontal) remanent direction. Because the geomagnetic field would not be expected to maintain a direction such as this for extended periods or 


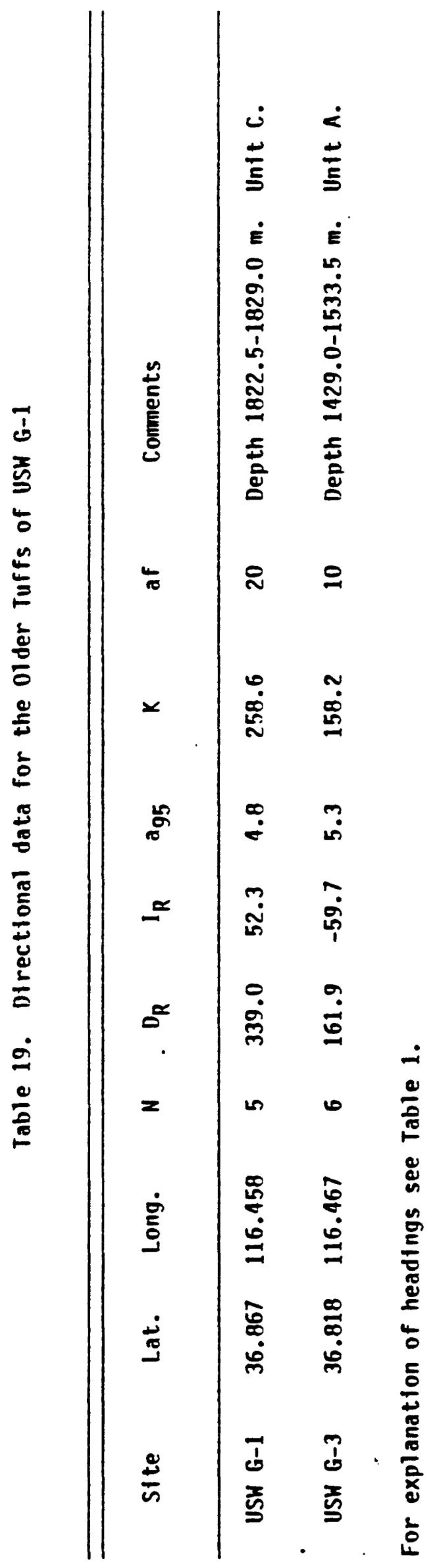




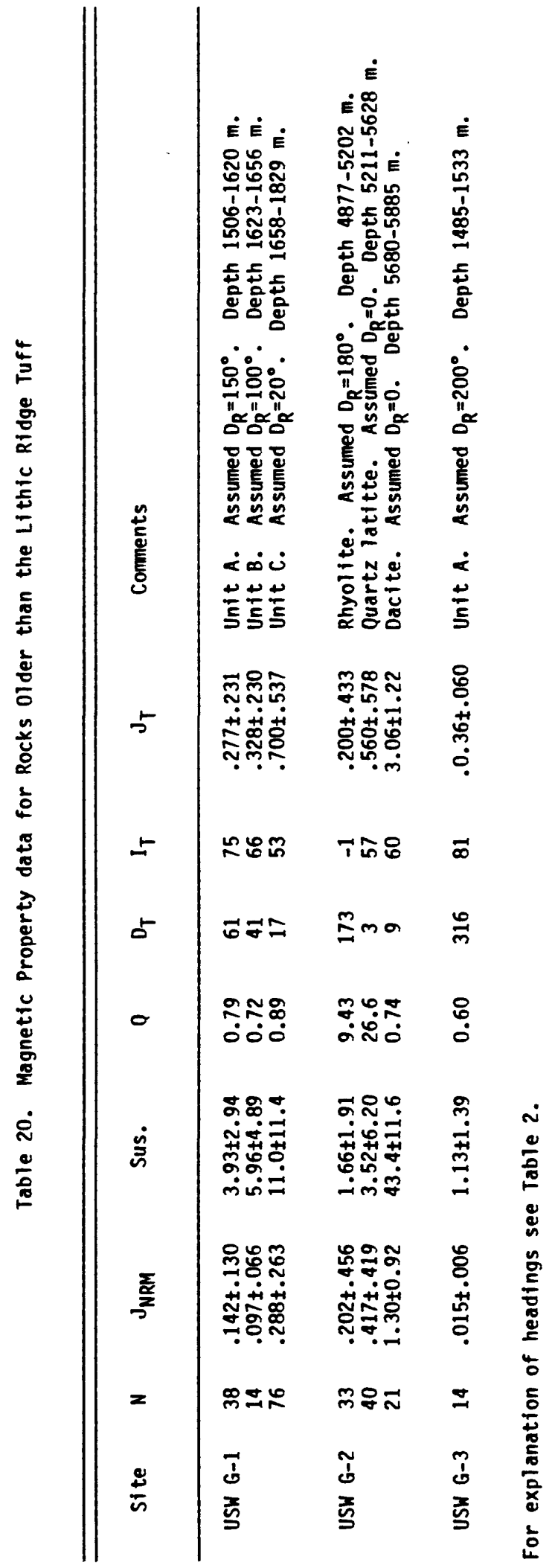




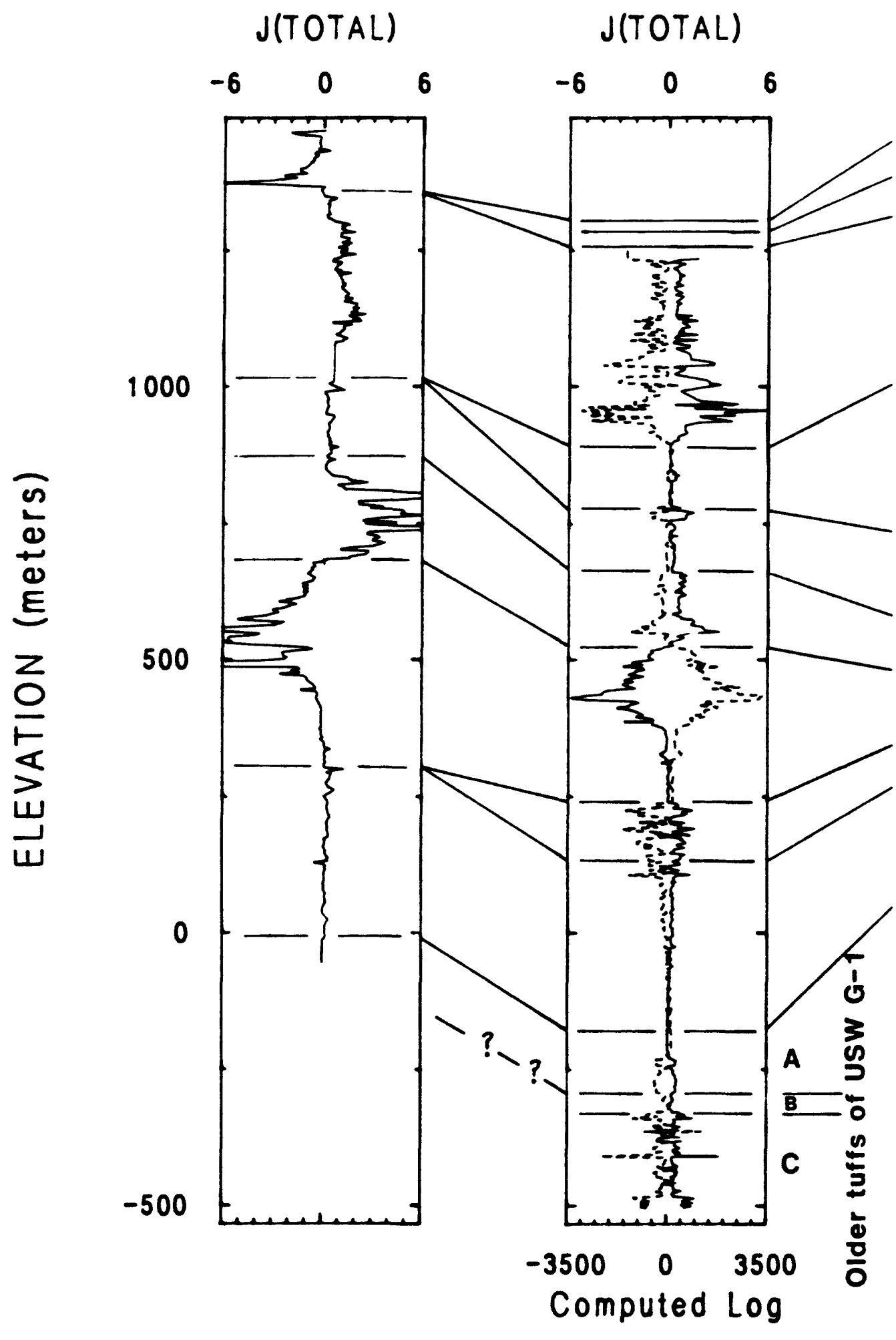

USW GU-3 and. G-3 USW G-1

Figure 24.-Total magnetization $\left(\mathrm{Am}^{-1}\right)$ versus depth (so11d 11nes) for drill holes USW G-1, G-2, GU-3, and G-3, and modeled total field log (dashed 


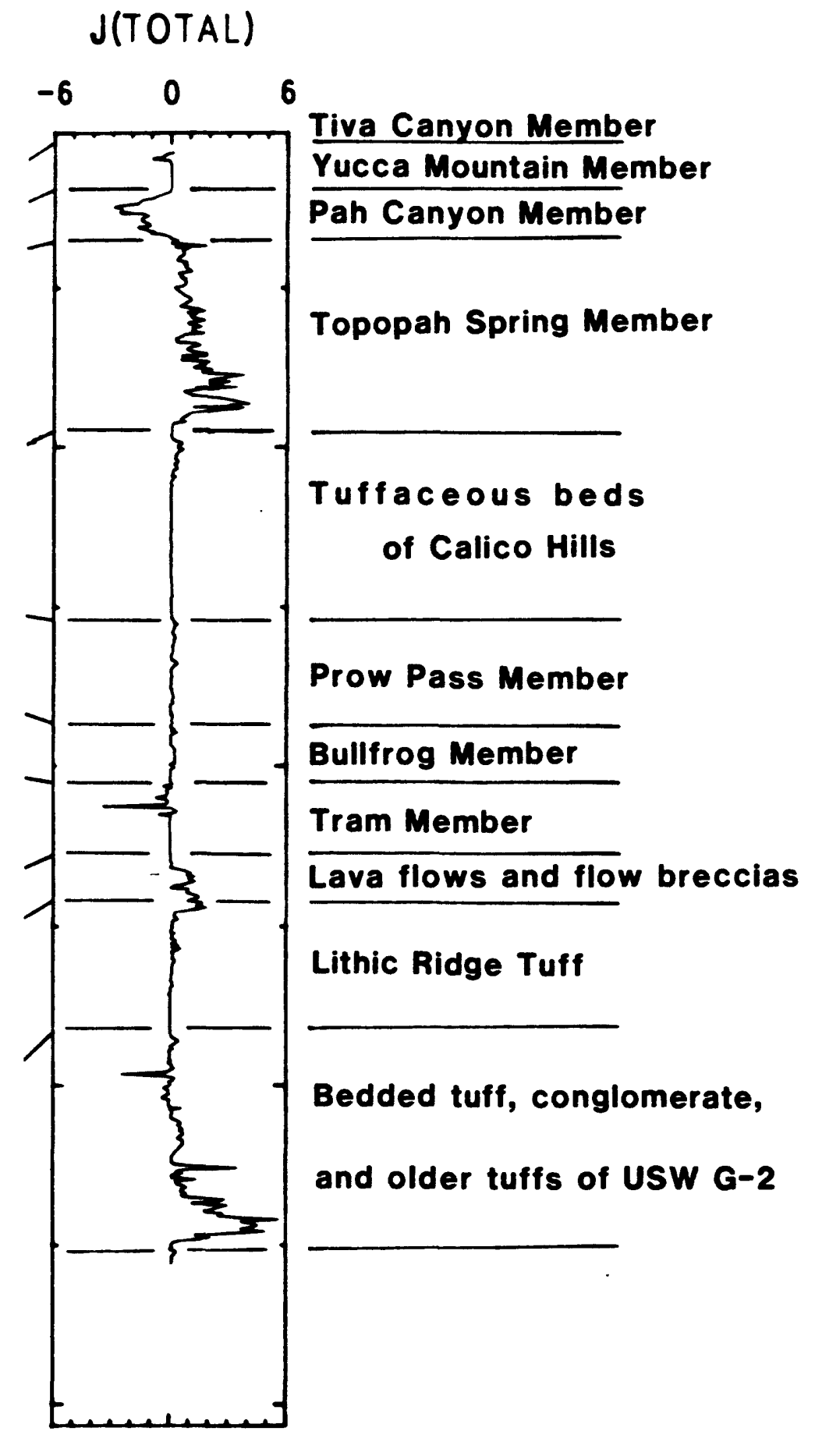

USW G-2

11ne) for drill hole USW G-1 (nT). Geologic contacts are from Spengler and others [1981], Maldonado and Koether [1983], and Scott and Castellanos [1984]. 
Table 21. Paleomagnetic Polarities of Volcanic Rocks at Yucca Mountain

\begin{tabular}{|c|c|c|}
\hline Unit & Polarity & Comments \\
\hline $\begin{array}{l}\text { Paintbrush Tuff: } \\
\text { Tiva Canyon Member } \\
\text { Yucca Mountain Member } \\
\text { Pah Canyon Member } \\
\text { Topopah Spring Member }\end{array}$ & $\begin{array}{l}R \\
R \\
R \\
N\end{array}$ & $\begin{array}{l}\text { Consistent directions. } \\
\text { Inclination about } 40^{\circ} \text {. } \\
\text { Inclination greater than } 60^{\circ} \text {. } \\
\text { Variable directions. }\end{array}$ \\
\hline Tuffaceous beds of Calico $\mathrm{H}$ & ills & \\
\hline $\begin{array}{l}\text { Crater Flat Tuff: } \\
\text { Prow Pass Member } \\
\text { Bull Irog Member } \\
\text { Tram Member }\end{array}$ & $\begin{array}{l}N \\
N \\
R\end{array}$ & \\
\hline $\begin{array}{l}\text { Dacite and Rhyodacite } \\
\text { ( in USW } G-1, G-2 \text {, and } H-6 \text { ) }\end{array}$ & N? & Based on inc. data from USW $H-6$. \\
\hline Lithic Ridge Tuff & Intermediate & $\begin{array}{l}\text { Nearly horizontal to the } \\
\text { southwest. }\end{array}$ \\
\hline$\underset{A}{\text { Older Tuffs of USW G-1: }}$ & $R ?$ & $\begin{array}{l}\text { Based on oriented core from } \\
\text { USW G-3. }\end{array}$ \\
\hline $\begin{array}{l}\mathrm{B} \\
\mathrm{C}\end{array}$ & $\stackrel{?}{\text { N? }}$ & $\begin{array}{l}\text { Based on oriented core from } \\
\text { USW G-1. }\end{array}$ \\
\hline $\begin{array}{l}\text { Lavas in USW G-2: } \\
\text { rhyol ite } \\
\text { quartz latite } \\
\text { dacite }\end{array}$ & $\begin{array}{l}\mathrm{R} \\
\mathrm{N} \\
\mathrm{N}\end{array}$ & $\begin{array}{l}\text { Based on inclination data. } \\
\text { Based on inclination data. } \\
\text { Based on inclination data. }\end{array}$ \\
\hline 01der tuffs of USW G-2 & $?$ & \\
\hline
\end{tabular}


to frequently occupy such a position, determination of this direction from other localities would strongly support correlation to the Lithic Ridge Tuff.

In addition, inclination data from the tuffaceous beds of Calico Hills suggest that the relatively thin section encountered in drill hole USW G-1 is correlative with only the lowermost $125 \mathrm{~m}$ or so of the much thicker section encountered in drill hole USW G-2.

Two points bearing upon the structure of Yucca Mountain should be emphasized. First, paleomagnetic directions from the Tiva Canyon Member of the Paintbrush Tuff indicate that there has been no relative rotation of more than a few degrees between the sampling sites after emplacement of this unit. Therefore, the rather large, sharp change in strike observed in both the eutaxitic foliation and the base of the Tiva Canyon Member is not due to rotation about a vertical axis, and may be either a depositional feature or due to small rotations about horizontal axes. Second, the acquisition of data demonstrating very large directional variations of the remanent magnetism of the Topopah Spring Member largely invalidate the paleomagnetic evidence for left-lateral strike-slip movement on faults within Drill Hole Wash [Spengler and Rosenbaum, 1980].

Bath and others [1983] have arbitrarily set the following limits to characterize rocks for the purpose of describing their potential for producing magnetic anomalies:

$$
\begin{gathered}
\text { nonmagnetic }<0.05 \mathrm{Am}^{-1} \\
0.05 \mathrm{Am}^{-1}<\text { weakly magnetic }<0.50 \mathrm{Am}^{-1} \\
0.50 \mathrm{Am}^{-1}<\text { moderately magnetic }<1.50 \mathrm{Am}^{-1} \\
1.50 \mathrm{Am}^{-1}<\text { strongly magnetic. }
\end{gathered}
$$

Inspection of Figure 24 reveals that there are four arealy extensive ash-flow sheets which possess moderate to strong magnetizations throughout substantial stratigraphic thicknesses, and are therefore considered to be likely sources of magnetic anomalies. These units are the Tiva Canyon and Topopah Spring Members of the Paintbrush Tuff, and the Bullfrog and Tram Members of the Crater Flat Tuff. The Tiva Canyon and Tram Members are reversed, and the other two units are of normal polarity. Although data from only three samples of the tuff of Chocolate Mountain (the intracaldera equivalent of the uppermost layers of the Tiva Canyon Member) are available, this unit appears to be highly magnetic and certainly must be considered as a possible anomaly source. The reversely magnetized Pah Canyon Member is also moderately to strongly magnetic. However, it is not considered to be an important source of magnetic anomalies because it is thin and of limited areal extent. Also, the lavas between the Tram Member of the Crater Flat Tuff and the Lithic Ridge Tuff reach moderate to strong magnetizations (Fiqures 20 and 24 , and Table 18). The thickness of this unit varies greatly (Figure 20), and it therefore must be considered a possible anomaly source.

In addition to the units penetrated in drill holes at Yucca Mountain there obviously may be deeper anomaly sources. Possible deep sources include other volcanic rocks, plutonic rocks, and altered sediments like those encountered in drill hole UE25a-3 at Calico Hills [Baldwin and Jahren, 1982].

The results raise two major questions about the magnetization of welded tuffs. The cause of variations in the directional data from the Topopah 
Spring Member are presently unknown. Several possible explanations are: 1) that the entire unit was emplaced over a relatively long period of time with respect to secular variation; 2) that the unit was emplaced quickly but cooled over a relatively long period; and 3) that internal deformation of the cooling unit took place at temperatures below that at which much of the magnetization was acquired. Regardless of the cause, such variations severely limit the usefulness of paleomagnetic directions from the Topopah Spring Member as an aid to structural interpretation.

The other question concerns the origin of the large lateral and vertical variations of magnetic properties observed within single cooling units. Mechanisms which could contribute to the variations include: (1) differences within the magma in composition, quantity, and grain size of the magnetic phase at the time of eruption; (2) post-emplacement growth of differing quantities and grain sizes of magnetic phases; and (3) varying degrees of alteration with attendant oxidation of highly magnetic magnetite to less magnetic hematite. The position of remanent intensity maxima between depositional breaks in the Bullfrog and Tram Members of the Crater Flat Tuff encountered in drill hole USW GU-3 and G-3 (Figures 16 and 18) strongly suggests some relation of the magnetic property variations to emplacement history.

Figure 24 displays a calculated magnetic field log for drill hole USW G-1. The model used to generate the $\mathrm{log}$ consists of a large number of thin sheets. Each sheet corresponds to a sample and extends half the distance to the overlying sample and half way to the underlying one. Each sheet was assigned a uniform magnetization equal to the total magnetization computed for the corresponding sample. The magnetic field produced by the model was calculated at about $3 \mathrm{~m}(10 \mathrm{ft})$ depth intervals at the center of a hexagonal hole approximately $0.3 \mathrm{~m}(1 \mathrm{ft})$ in diameter. The modeling results indicate that the magnetic field variations should have amplitudes of several hundred to several thousand $\mathrm{nT}$. There is therefore a good possibility of using magnetization variations, as determined from in-hole magnetic logs in closely spaced holes, as an aid in locating not only major stratigraphic contacts but also to map zones within complex compound cooling units.

\section{REFERENCES CITED}

Baldwin, M. J., and Jahren, C. E., 1982, Magnetic properties of drill core and surface samples from the Calico Hills area, Nye County, Nevada, U. S. Geological Survey, Open-File Report 82-536, 27 p.

Bath, G. D., and Jahren, C. E., 1984, Interpretations of magnetic anomalies at a potential repository site located in the Yucca Mountain area, Nevada Test Site, U. S. Geological Survey, Open-File Report 84-120, 53 p.

Bath, G. D., Jahren, C. E., Rosenbaum, J. G., and Baldwin, M. J., 1983, Magnetic investigations, Chapter $C$ in Geologic and Geophysical investigations of $\mathrm{Cl}$ imax Stock intrusive, Nevada, U. S. Geological Survey, Open-File Report 83-377,p. 40-77. 
Byers, F. M., Carr, W. J., Orkild, P. P., Quinlivan, W. D., and Sargent, K. A., 1976, Volcanic suites and related cauldrons of Timber Mountain-0asis Vailey caldera complex, southern Nevada, U. S. Geological Survey, Professional Paper 919, 70p.

Carr, W. J., Byers, F. M., Jr., and Orkild, P. P., 1984, Stratigraphic and volcano-tectonic relations of Crater Flat Tuff and some older volcanic units, Nye County, Nevada, U. S. Geological Survey Open-File Report 84-114, 42p.

Christiansen, R. L., Lipman, P. W., Carr. W. J., Byers, F. M., Jr., Orkild, P. P., and Sargent, K. A., 1976, The Timber Mountain-Oasis Valley caldera complex of southern Nevada, Geological Society of America Bulletin, v. 87, p 943-959.

Christie, K. W., and Symons, D. T. A., 1969, Appatratus for measuring magnetic susceptibility and its anisotropy, Geological Society of Canada, Paper $69-41,10 \mathrm{p}$.

Creer, K. M., and Sanver, M., 1967, The use of the sun compass, in Methods in Pal eomagnetism, Coll inson, D. W., Creer, K. M., and Runcorn, S. K., ed., El sevier Publishing Company.

Hatherton, T., 1954a, The magnetic properties of the Whakamru ignimbrites, New Zeal and Journal of Science and Technology, v. 35, p. 421-432.

Hatherton, T., 1954b, The permanent magnetization of horizontal volcanic sheets, Journal of Geophysical Research, v. 59, p. 223-232.

King, R. F., 1955, Remanent magnetism of artificially deposited sediments, Monthly Notices of the Royal Astronomical Society, Geophysical Supplement, v. 7, p. 115-134.

Maldonado, F., and Koether, S. L., 1983, Stratigraphy, structure, and some petrographic features of Tertiary volcanic rocks at the USW G-2 drill hole, Yucca Mountain, Nye County, Nevada, U. S. Geological Survey Open-File Report 83-732, 83p.

Rosenbaum, J. G., Larson, E. E., Hoblitt, R. P., and Fickett, F. R., 1979, A convenient standard for low-field susceptibility calibration, Review of Scientific Instruments, v. 50, p. 1027-1029.

Scott, R.B., and Castellanos, M., 1984, Preliminary report on the geologic character of drill holes USW GU-3 and USW G-3, U. S. Geological Survey Open-File Report 84-491, 121p.

Spengler, R. W., Byers, F. M., Jr., and Warner, J. B., 1981, Stratigraphy and structure of volcanic rocks in drill hole USW G-1, Yucca Mountain, Nye County, Nevada, U. S. Geological Survey Open-File Report 81-1349, 50p.

Spengler, R. W., and Rosenbaum, J., G., 1980, Preliminary interpretations of geologic results obtained from boreholes, UE25a-4, $-5,-6$, and -7 , Yucca Mountain, Nevada Test Site, U. S. Geological Survey, Open-File Report $80-929,33 p$. 